\title{
Acacia Plantation Development and the Configuration of Tree Farmers' Agricultural Assets and Land Management-A Survey in Central Vietnam
}

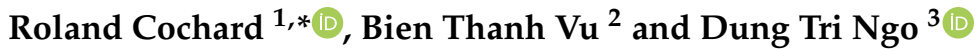 \\ 1 Faculty of Geosciences and Environment, Institute of Geography and Sustainability, University of Lausanne, \\ CH-1015 Lausanne, Switzerland \\ 2 Faculty of Natural Resources and Environment, Vietnam National University of Agriculture, Hanoi 131000, \\ Vietnam; vtbien@vnua.edu.vn \\ 3 Consultative and Research Centre on Natural Resource Management (CORENARM), Hue City 530000, \\ Vietnam; dzungtringo@corenarm.org.vn \\ * Correspondence: roland.cochard@unil.ch
}

check for updates

Citation: Cochard, R.; Vu, B.T.; Ngo, D.T. Acacia Plantation Development and the Configuration of Tree Farmers' Agricultural Assets and Land Management-A Survey in Central Vietnam. Land 2021, 10, 1304. https://doi.org/10.3390/land10121304

Academic Editor: Hossein Azadi

Received: 8 October 2021

Accepted: 19 November 2021

Published: 26 November 2021

Publisher's Note: MDPI stays neutral with regard to jurisdictional claims in published maps and institutional affiliations.

Copyright: (c) 2021 by the authors. Licensee MDPI, Basel, Switzerland. This article is an open access article distributed under the terms and conditions of the Creative Commons Attribution (CC BY) license (https:// creativecommons.org/licenses/by/ $4.0 /)$.

\begin{abstract}
Since 1990 acacia-based tree plantations have fast expanded in Vietnam, now supporting a multi-billion-dollar export-oriented wood industry which is transforming from woodchip production to value-added products. Within this dynamic context, tree farmer associations have started to produce sawlogs under FSC (Forest Stewardship Council) certification. In this paper, we retrace the development of plantation assets, investigating farmers' current livelihoods and land management, specifically considering various aspects of sustainability. We interviewed 180 tree farmers in three districts (lowland-upland regions) of Thừa Thiên Huế Province, including sawlog producers with and without FSC and smallholder producers of woodchips. Acacia planting in 'barren lands' was initiated through state programs in the 1990s (low-/midlands) and 2010s (uplands). Farmers now producing FSC sawlogs were among the first to gain forestland tenure; they now own large plantations (on good terrain), are in tune with policies and maintain resources/capacities to adopt management in line with FSC standards. Yet, most farmers also retain plots for easy-to-manage and low-risk woodchip production. Soil/vegetation conservation depends on farmers' status/capacities and environmental awareness; FSC membership added economic-political benefits. Findings are discussed within a regional historic context. Plantations contribute to economic development, but issues persist/emerged in terms of land equity and environmental governance, risks (e.g., plant pathogens), and spaces/impetus for farm-based innovation and adaptiveness.
\end{abstract}

Keywords: land use change; tree planting programs; forestland tenure and policies; arboriculture; acacia timber production; Forest Stewardship Council; soil conservation; livelihoods and sustainability

\section{Introduction}

Vietnam's forested landscapes, the living space of people of different ethnicities, languages and environmental-cultural traditions, have gone through profound changes. In very broad terms, three periods of forest-related changes may be identified, i.e., a period of (1.) 'natural forest decline' (until 1990), (2.) 'forest transition' ( 1990-2005), and (3.) plantation-based 'new forestry' ( 2005 until now) [1,2]. Until recently, the 'new forestry' period was largely characterized by smallholder short-rotational plantations [3], but there is an increasing trend towards structural-industrial re-arrangements, with state policies favoring larger land holdings and promoting technically 'advanced' types of plantation management [4-10]. In alliance with international initiatives, new development objectives are thereby forged in accordance with specific formulations of 'sustainability'. Many developments (past and current), however, come with trade-offs and result in variable outcomes across social strata and environmental spaces/aspects, raising a variety 
of questions with regard to 'sustainability', insofar as this relates to the UN's Sustainable Development Goals [11-15].

The overall objective of this study was to gain insights into the evolution and nature of a tree-based 'landscape of commodity production'. This is a landscape which has largely been determined by political-economic drivers, and which yields particular outcomes for 'sustainability' (or 'changeability') associated with environmental qualities, land management practices, livelihoods, and the social potentials (inclusions/exclusions) of different tree farmers (as well as other stakeholders). We undertook a survey of 180 farmer households in nine communes in Thừa Thiên Huế Province (TTHP) in Central Vietnam. The communes were located in three districts along a lowland-upland transect (Figure 1), capturing a range of environmental and socio-ethnic diversity in TTHP-characteristic of landscapes and population distributions of provinces in Central Vietnam. All the farmers were engaged in woodchip and/or timber production from plantations composed of non-native acacia trees (i.e., Acacia mangium or Acacia mangium $\times$ auriculiformis hybrids). Half of the farmers recently (since 2016) became members of an FSC Association (the Thừa Thiên Huế Forest Owners Sustainable Development Association, TTH-FOSDA [16,17]). Hence, they now produce all or some timber under specific 'sustainability' criteria as defined, certified, and controlled by the Forest Stewardship Council (FSC), an international multi-stakeholder organization with headquarters in Germany. The other farmers were not FSC members and were primarily engaged in acacia woodchip production.

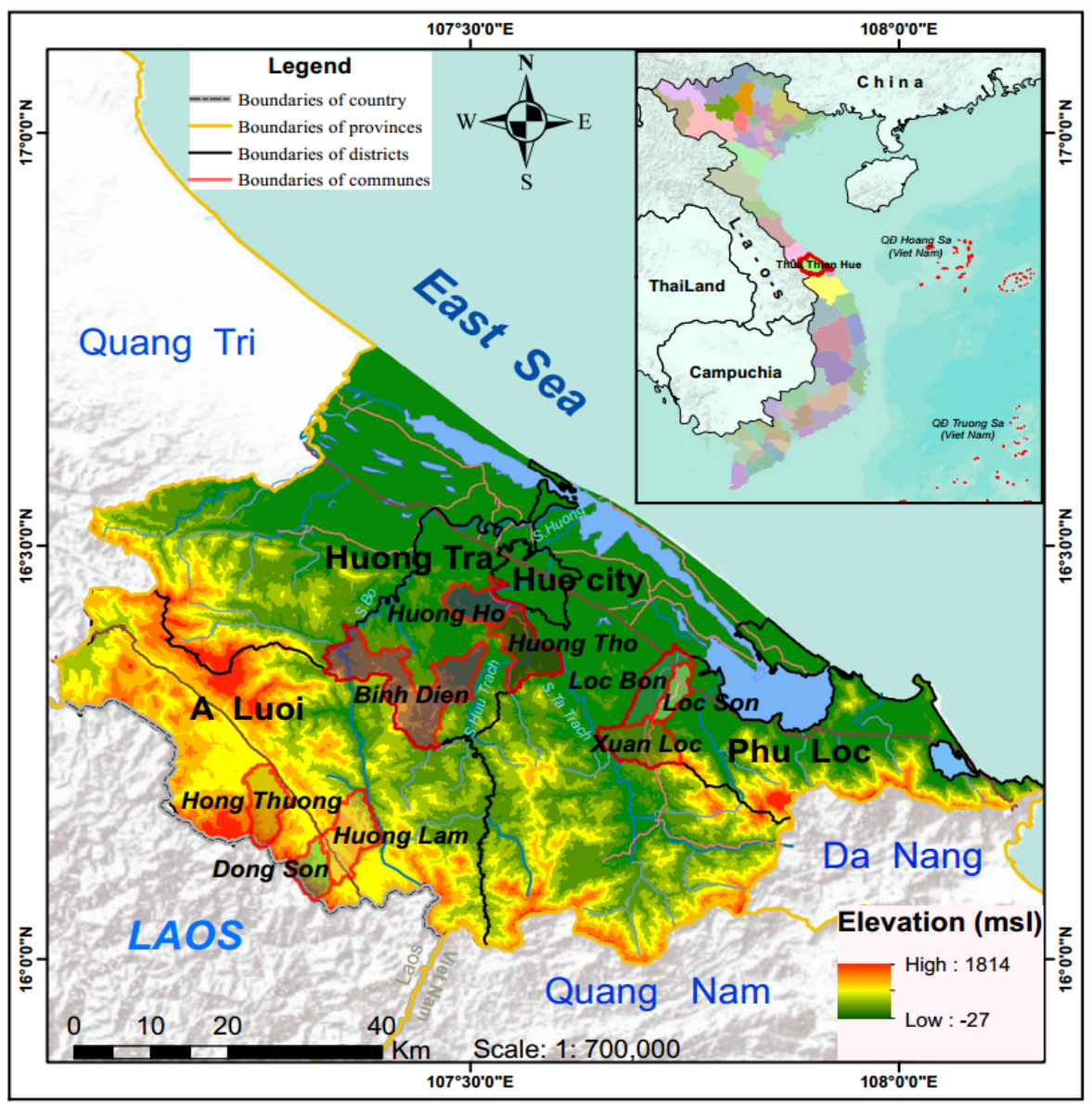

Figure 1. Map showing the location of the nine surveyed communes within three districts in Thừa Thiên Huế Province, Central Vietnam. Map by B.T.V.

We investigated the timelines and initial processes by which the farmers became enrolled in acacia farming and related these 'development patterns' to the farmers' profiles of plantation land holdings, forms of resource management, as well as other livelihood activities and agricultural/technical assets. The survey showed that FSC-farmers, especially 
in the lowlands, were generally better placed in status and plantation resources, primarily because of historic contextual reasons. At the time of the study, production of sawlogs, especially certified by FSC, represented an investment (in terms of plantation resources, time, and risk-taking) that still surpassed the capacities and potentials of many farmers. In a companion study (Bien Thanh Vu et al., in prep.), we focus more on the farmers' views and perceptions of environmental changes, contextual outlooks on developments (opportunities and risks), and on occupational perspectives.

\section{Background}

\subsection{The Study Area within Geographic-Historic Context}

Thừa Thiên Huế Province (area of $5033 \mathrm{~km}^{2}$; Figure 1) includes lowland coastal lagoons and plains (mainly rice fields), undulating hilly 'midlands' (nowadays largely covered by acacia plantations), and valleys in mountainous uplands (covered by natural forests and partly plantations). TTHP encapsulates many of Central Vietnam's historical and present development trajectories. Huế City was Vietnam's pre-colonial capital. TTHP was located at the center of the 'American War' (1955-1975). Today, TTHP is a magnet of industrialization and agricultural development [18-20], and it is a microcosm of recent developments in forestry in Vietnam. Around $3111 \mathrm{~km}^{2}(62 \%)$ of TTHP were covered by 'forests' in 2018; of this total, $989 \mathrm{~km}^{2}$ (32\%) were 'planted forests', with acacias being the predominant species [21]. TTHP was one of the first provinces in Central Vietnam to implement programs promoting 'sustainable forestry' in terms of FSC-defined criteria [16,22]. Such programs have been promoted by governmental agencies at various levels (i.e., the Thừa Thiên Huế Department of Agriculture and Rural Development TTH-DARD, the Forest Protection Department TTH-FPD, People's Committees), in collaboration with international agencies and NGOs (mainly the World Wildlife Fund, WWF) and/or corporations (Scansia Pacific). In 2016, the provincial government planned ${ }^{1} 130 \mathrm{~km}^{2}$ of 'forest' ( 13\% of current plantation area) by 2020 for saw-log production, with FSC-certified plantations targeted at $40 \%$ (i.e., $~ 52 \mathrm{~km}^{2}$ [23]). In 2018 there were 780 farmers with in total $38.6 \mathrm{~km}^{2}$ FSC-certified plantations. Until 2020 this increased to 1057 farmers and $51.7 \mathrm{~km}^{2}$ FSC plantation cover (representing 5.2\% of 'planted forest' area) [24].

The rise of acacia plantation forestry in TTHP (and other parts of Central Vietnam) may be seen on the background of wider historical socio-political developments, and within the engravings of the province's highly variable terrain. Distinctive regional differences and inherent histories may be described considering the three districts where we conducted the survey, namely coastal-lowland Phú Lộc District (elevation $\sim 0-60 \mathrm{~m}$ above sea level), midland Hương Trà District ( 30-250 m a.s.l.), and upland A Lưới District (>560 m a.s.1.) (Figure 1, Table 1).

Phú Lộc District, including Lộc Sơn and Lộc Bổn Communes (Figure 1), has a centuriesold history of human settlement dating back to the times of the Champa Kingdom and earlier [18]. People traditionally subsisted on paddy fields of the coastal alluvial plains. Many nearby inland lowland forests were already cut in pre-colonial times and were replaced by woodlands which continued to serve the communities as sources of wild foods and wood for housing and for energy (firewood, charcoal) $[18,25]$. Over the passage of time and growing populations and especially during conflicts, many of these woodlands degraded in quality. Notably, at the height of the 'American War' ( 1966-1972) tracts of land were occupied as army camps and used for other military activities, with the outcome that woodlands turned into brushlands and bare lands with compacted soils [18,25]. Xuân Lộc Commune, which is located more inland (Figure 1), was founded in $1975^{2}$ as part of the national government's Resettlement Program. The communities in Phú Lộc are mainly composed of Kinh people (i.e., Vietnam's majority people, but partly of mixed heritage), but one village in Xuân Lộc is inhabited by Bru-Vân Kiều people, who were resettled there in 1983 from their original homelands in upland Quảng Trị Province [26].

The history of upland TTHP is quite different from the lowlands (and has been off records for much of the time). The uplands were included into the national territory on the 
maps of pre-colonial kings and the French colonial administrations, and the 'uplanders' attracted the interests of ethnographers early on [27]. Despite this, the densely forested landscapes embedded within the Trường Sơn mountain chain along the border of Laos remained mostly a 'world apart' — up until the end of the French colonial period [18,27]. The territory which now forms A Lưới District, was (and still is) inhabited by people speaking katuic languages, namely the Cơ Tu, Tà Ôi, and Bru-Vân Kiều. These people gained their livelihoods from small-scale shifting swidden agriculture within variable terrain and from wild products derived from the dense surrounding rainforests. In the 1950-1960s 'modernity' violently broke into this world. During the 'American War', fierce battles raged in A Lưới Valley (at the time often referred to as the A Shau Valley) which, with its dense forest cover, provided a main passageway for the infiltration of North Vietnamese army units to South Vietnam. Various events are recounted in military histories; these can however be expected to have a differing reading from a local perspective. It is other literature [27-29] that points readers towards comprehending the hardships and displacements endured by upland people during those times. Returning communities regained a living in A Lưới after the war, within landscapes widely scarred by effects of ammunition and chemical defoliants [30]. Yet, 'modernity' eventually made further inroads through 'development'. During the 1990s many communities were re-settled by government programs from remote areas to the main A Lưới Valley, with the emptied areas subsequently being developed for hydro-electric dams, for nature conservation, and for timber production forestlands of state-owned forest companies (SFCs) [27,31-34]. Swidden agriculture and many forest uses were prohibited by law, impelling the communities to adopt new, more intensive forms of agricultural land management and monocrops (rice, cassava, acacia plantations, aquaculture), at the sacrifice of diverse traditional methods of resource production and subsistence [1,26,27,35-39]. Conversely, in some communes (e.g., Đông Sơn) where soils were contaminated with dioxins from the spraying and spilling of the defoliant Agent Orange during the war [40], the planting of acacias may also have provided new lower-risk agricultural opportunities.

The development of Hương Trà District followed yet a different line of history. Old maps based on aerial images show that the undulating hills of Hương Trà were still mostly covered by rainforest in the early 1960s. Except for some incipient settlements along the track connecting Huế City with remote A Lưới Valley (now Road 49), many of today's villages did not yet exist at the time. These rainforests were largely destroyed during 1968-1971 as a result of military air strikes and the spraying of airborne herbicides (mainly the infamous Agent Orange [18,41]). In addition, large army camps were set up in 1968/1969 along Road 49, impacting the surrounding terrain. After the war, the wood of forest remnants was used for reconstruction and energy production (firewood and charcoal); much of the landscape was thus converted into an open bushland. This opened area could eventually be colonized and economically 're-developed' by settlers engaged in plantation forestry. In suitable locations, settlers initially planted eucalypt woodlots, orchards, and rubber plantations. In the 1990s, extensive acacia plantations were planted under the aegis of large 'reforestation programs'.

\subsection{Acacia Plantation Development: Outset, 'Reforestation' Programs, and Forestland Allocation}

Forest decline in TTHP — whilst starting in pre-colonial times-was thus markedly associated with war-related destructive events before 1975. Nonetheless, post-war forest exploitation by state-owned forest enterprises (logging for reconstruction and timber exports for foreign exchange), early communist policies (fostering inland migration and resettlement, and introducing collective land use systems), and fast population growth added to pressures on remaining intact natural forests during the 1970s-1990s [1,18]. By the early 1990s most rural communities still made a (sometimes precarious) living from more or less 'conventional' land use systems (irrigated paddy fields, rotational hillside swidden fields, and open access to wild forest products [42]); yet, many preconditions were already set for the remarkable 'career' of plantation-based 'new forestry' systems. By the end of 
the 1980s state-led forestry was in crisis because logging in natural forests was no longer profitable. Restoration of native timber proved to be unfeasible. Vast 'forestlands' lay unproductive as so-called 'bare hills' - even if these areas were still a source for livelihoods (e.g., firewood, wild foods) for many poor households [1,25,43]. By contrast, scientific trials during the 1980s had shown that the fast-growing nitrogen-fixing alien species of acacias could be readily grown on degraded soils; the species opened new potentials for so-called 'forest restoration', new tree-based livelihoods, and rural economic development [44-47].

In the wake of nation-wide reforms (Đổi Mới, 'Renovation' in 1986) towards a socialistoriented market economy, the 'transition period' was marked by significant shifts in forestry and land use governance, with much emphasis on 'reforestation' [1,2,48,49]. State forest enterprises (SFEs) were re-organized into either state forest companies (SFCs; with objectives of advanced economic forestry) or forest protection management boards (FPMBs; with objectives of forest protection and restoration); accordingly, forestlands were divided into zones for production, protection, and special use. Local communities were mobilized by SFEs/SFCs/FPMBs to participate in forest restoration and protection activities. The opening of the country to international cooperation and foreign investments during the 1990s allowed for the implementation of large, internationally funded reforestation programs, such as Program 327 ('Greening the Barren Hills Program'; 1993-1998) and Program 661 ('5 Million Hectare Reforestation Program’; 1998-2010 [50]) which followed earlier country-wide programs sponsored by the UN World Food Programme (1976-2000; 'PAM programs'-Programme Alimentaire Mondiale [1,51]). The funds from such programs (at national level over USD 2 billion in total) assisted the development of tree nurseries, the reorganization of forestry organizations, payments of rural labor, and-consequently-the set-up of vast 'planted forests', which were mostly monocultures of fast-growing exotic acacias $[1,12,43,49]$. National programs, with international support, also fostered the development of sawmills and wood factories, and the improvement of road networks which enabled transport of wood harvests [52-54].

Most importantly, state-led programs for 'forest land allocation' (FLA) to individual households during the 1990s-2000s facilitated 'forest planting' via so-called 'socialization', as local households could obtain land titles to (mostly degraded) forestlands as well as state subsidies to set up tree plantations. Land titles for designated forestland plots (valid for a period of 20-50 years) were issued by state authorities via 'Red Books', but the processes of FLA were often non-transparent and were usually explicitly or implicitly linked to specific expectations and policy targets of the state to render the lands productive through a specific crop or tree species $[12,55]$. Many communities in the largely deforested lowlands and hilly midlands of TTHP could profit from new opportunities provided by land titling. The process of FLA however often disadvantaged poor/illiterate farmers and/or farmers (often of minority groups) who were generally not in tune with the latest state-led development initiatives; many of these farmers depended on incomes generated from communal lands which were now transformed into private plantations $[1,36,43,56,57]$. In the uplands FLA programs disrupted (and new laws prohibited) traditional shifting cultivation agriculture (i.e., swidden systems which were usually managed as commons) in state-designated 'forestlands', and state forest organizations set in place increasingly stringent restrictions and controls on natural forest uses. As a result, FLA initially often met with resistance from upland communities, or otherwise proved to be impracticable within a complex sociopolitical environment; accordingly, for a long time, acacia plantations were not 'self-starters' in the upland areas $[26,37,38,55,58,59]$. Notwithstanding, pressed forward by stringent national regulatory policies and expedited by attractive market prices for wood products, the acacia plantation boom has penetrated the remotest upland areas during the last decade, with plantations sometimes encroaching onto steep forestlands $[10,31,36,60,61]$.

\subsection{The Rise of Wood Certification Schemes: Developing New Markets-With} More 'Sustainability'?

FLA secured farmers' ownership of land and profits from trees, making labor investments worthwhile for them; this was an important pre-requisite for reaching specific state 
objectives in establishing a plantation-based national wood industry [62]. As stipulated in the Land Law, households are permitted to sell, rent, mortgage, or trade their allocated forestland plots. Nonetheless, in reality the farmers' choices are still restricted through various state regulations, including legal conditions/requirements and the provisioning of subsidies and extension services [55,63]. In addition, land ownership ultimately remains with the state ${ }^{3}$ and state priorities (e.g., meeting specific production quotas or predefined export targets) often take a lead in farmers' choices, despite other potentially important issues which lie more within a farmer's scope, and which may require locally fitting responses/adaptations in land/plantation management.

Vietnam's wood industry now employs over five million people (arboriculture, wood processing, furniture assembly, etc. [12]). It constitutes the country's fourth largest export industry; the export value has risen steeply from USD 3.4 billion in 2010 to USD 8.9 billion in 2018 and USD 12.5 billion in 2020 and is on a continued growth trajectory [64,65]. Despite of this apparent economic success, the booming industry continues to be subjected to significant structural challenges and risks. In 2018 , over $70 \%$ of the plantation-derived wood was used for low-value woodchip production, making Vietnam the number one exporter of woodchips globally [66]. Woodchip exports are, however, highly dependent on the Chinese (58\% of woodchip exports in 2018 ) and Japanese (33\%) markets; any volatility in those markets (e.g., during the COVID-19 crisis) can significantly affect woodchip prices $[65,67,68]$. Conceivably, even more important for developments in national policy is the fact that the largest turnover from exports of wood products (more than $70 \%$ [6]) has come from high value-added wood products such as furniture, with strong consumer markets (largely controlled by international corporations) in the United States and Europe, in addition to China and other Asian countries (and with rising demand during the COVID-19 crisis) [64,69]. As is the case, however, only a small amount of wood from Vietnam's plantations can be used for furniture production; to cover industry needs in 2018, Vietnam had to import raw timber/lumber valued at USD 1.6 billion [65]. Until relatively recently, high-quality timber was still imported at fairly low economic costs from neighboring Laos, Cambodia, and Malaysia, and countries in Africa [65,69,70], but decreasing timber stocks in those countries, in combination with international disproval of destructive logging in rainforests, has led to some reorientation. At least by pronouncement, the central government has subscribed to various international commitments to comply with standards set by countries that buy Vietnamese wood products [71] ${ }^{4}$; accordingly, major Vietnamese wood traders have become increasingly aware of such standards and requirements, and associated business opportunities, risks, and niches [72]. In recent years Vietnam has started to import more and more 'non-risk timber' from Canada and the US [65] or FSC-certified acacia timber from other parts of Southeast Asia [17]. Yet, this alone can barely compensate the fall-out of previously regional rainforest-sourced timber, nor does it constitute a robust basis for reaching the government's wood industry growth targets.

Vietnam's government has thus set a policy agenda to increase the supply of domestic plantation-sourced timber for the furniture industry. In 2015 it set a five-year target to increase the production of furniture wood from 4.5 million tonnes to 6.5 million tonnes, whilst reducing woodchip exports from 6 million tonnes to 3 million tonnes [73]. In order to achieve better international market access and higher selling prices, and to introduce more advanced and 'sustainably-managed' schemes of production, the drive for longer-rotation cycles is linked to efforts for developing the plantations according to standards of international wood certification. To obtain certification from major international organizations of certification, such as the Forest Stewardship Council (FSC) or the Programme for the Endorsement of Forest Certification (PEFC), groups of wood producers need to form an association which, in total, covers a plantation area of at least $~ 3000$ hectares [5]. In Central Vietnam several such associations have already formed, often with the aid of initiatives by local organizations and/or international development agencies, as well as through investments by multi-national corporations, such as IKEA, and in cooperation with international 
NGOs, such as the World Wildlife Fund (WWF) $[5,6,16,17,22,74,75]$. Within this context, acacia-based plantation systems that integrate the production of slow-growing, native, high-value timber species (e.g., Tarrieta javanica, Dipterocarpus allatus, Hopea odorata) have recently been under trial and have been discussed during workshops [76,77].

Timber certification through labels such as FSC reaches buyers of furniture with a promise of wood production and trading under 'sustainability standards'. Yet, it may be arguable how 'sustainability' could and should be circumscribed. FSC-certified plantationbased timber may provide 'sustainability' benefits because (1.) acacia production processes are- under normal conditions-fairly reliable, with predictable profits [6,78,79], (2.) plantation systems (plots) can be managed/controlled according to certain FSC-defined standards (e.g., disallow uses of synthetic pesticides [80]) Ref. [81], (3.) plantation-based timber may offset some uncontrolled logging from biodiverse rainforest [82,83], and (4.) institutionalized practices under FSC may foster improved plantation planning and management and more exchange and participative processes among FSC member communities [84-86]. Policy-driven expansion of FSC-certified acacia timber production will, however, replace other types of land management through the accumulation of land and simplification/normalization of more industrialized land use systems $[4,17,87]$. What 'sustainability' (or 'sustainable development') thereby means for more vulnerable and marginalized stakeholders (e.g., smallholder tree farmers, communities of ethnic minorities, women, and others) may distinctly differ from the views of more dominant and well-established actors [13,56,88-91]. Furthermore, 'sustainability' (in a more 'scientific-technical' sense) is not an end-state but rather a knowledge-based iterative process; adequate technical innovations and adaptive capacities are not always aided by 'knowledge' that is promulgated by institutions as fixed 'standards' [92-94].

There are general 'sustainability' questions relating to changes of land management and associated knowledge and practice. The rise of acacia plantations (on privately owned lands) has brought about significant environmental changes and new dependencies, with largely unknown consequences. Plantations grow on soils which once were covered by biodiverse rainforests. After plantation harvesting (clear-cutting), the soils lay bare and vulnerable to erosion, and imbalances/deficiencies of soil nutrients may require nutrient inputs from ash or costly fertilizers [44,95]. Furthermore, the plantations are contiguous singlespecies monocultures which can be highly susceptible to plant pests and diseases [96-98], as well as weather-related impacts such as storms [99-101]. Losses of traditional/local ecological knowledge are partly associated with such environmental concerns [89]. In Vietnam, the new agro-forestry regimes have largely replaced/superseded traditional nature-based 'cultures' of land management. This may itself affect options/opportunities for more diversified and inherently sustainable livelihoods [1,35,42,59]. Increased livelihood conformity and dependencies on plantation systems (and associated trade networks) may lead to increased exposure to potentially volatile regional and global markets, and associated political-economic pressures $[14,89]$.

\section{Methods}

\subsection{Questionnaire-Based Survey}

The questionnaire survey was conducted during September to November 2018. At that time 780 households were participating in FSC programs in TTHP, representing $2 \%$ of all households engaged in tree plantations within the province (38'949 farmers [102]). All selected communes had an FSC group. The FSC group leader could provide contacts, and ninety households participating in FSC certification schemes were thus selected (referred to as 'FSC-farmers'). Ninety households not engaged in FSC (referred to as non-certified 'Nc-farmers') were selected in the vicinity of FSC households. We were careful to include farmers of different plantation management types and ended up with four 'farmer types' (cf. Table 1) along a hierarchical gradient, i.e., (1.) 62 Nc-farmers who managed plantations for (non-certified) Nc-woodchip production only ('Nc-woodchip-farmers'), (2.) $28 \mathrm{Nc}$-farmers who had set aside some plantation area for Nc-sawlog production 
(sawlogs were not yet exploited; 'Nc-sawlog-farmers'), (3.) 63 FSC-farmers with—as yetunexploited plantations for FSC-certified sawlog production ('FSC «start〉-farmers'), and (4.) 27 'pioneering' FSC-farmers who, in 2018, had already exploited FSC-certified timber ('FSC «exploit>-farmers'). In addition to plots managed for timber production under FSCcertified standards, many FSC-sawlog producers also owned acacia plots for Nc-woodchip and/or Nc-sawlog production (Sections 4.5 and 4.6).

We employed a questionnaire (tested through a pilot study) with mainly open questions to obtain information about (1.) the profile and basic livelihood status of the respondents (question Q1-9), (2.) their history of involvement in plantation forestry and past experiences (Q10-16); (3.) current plantation and other agricultural assets (Q17-20), and (4.) acacia plantation management practices (Q21-32). The respondents' answers were recorded by the interviewer (Bien Thanh $\mathrm{Vu}$ ); on average an interview took about one hour. All respondents participated voluntarily. Prior to the interview the respondents were informed about the aims and scope of the study and the prospective length of the interview, and they were explicitly asked whether they would like to participate as respondents.

Table 1. The number of respondents interviewed in the communes of the three study districts, i.e., Phú Lộc, Hương Trà and A Lưới by farmer type, i.e., producers of non-certified woodchips only (Nc-woodchip), non-certified sawlogs (Nc-sawlog), and FSC-certified sawlogs which had (FSC «exploit`) or had not yet (FSC«start)) been exploited on some plots.

\begin{tabular}{|c|c|c|c|c|c|c|c|c|c|c|}
\hline \multirow{2}{*}{$\begin{array}{c}\text { District } \rightarrow \\
\text { Commune } \rightarrow \\
\text { Farmer Type } \downarrow\end{array}$} & \multirow[b]{2}{*}{ Total } & \multicolumn{3}{|c|}{ Phú Lộc (70) } & \multicolumn{3}{|c|}{ Hương Trà (70) } & \multicolumn{3}{|c|}{ A Lưới (40) } \\
\hline & & $\begin{array}{l}\text { Lộc } \\
\text { Bổn }\end{array}$ & $\begin{array}{l}\text { Lộc } \\
\text { Sơn }\end{array}$ & $\begin{array}{l}\text { Xuân } \\
\text { Lộc }\end{array}$ & $\begin{array}{l}\text { Bình } \\
\text { Điền }\end{array}$ & $\begin{array}{c}\text { Hương } \\
\text { Hồ }\end{array}$ & $\begin{array}{c}\text { Hương } \\
\text { Thọ }\end{array}$ & $\begin{array}{l}\text { Hương } \\
\text { Lâm }\end{array}$ & $\begin{array}{c}\text { Đông } \\
\text { Sơn }\end{array}$ & $\begin{array}{c}\text { Hồng } \\
\text { Thượng }\end{array}$ \\
\hline Total & 180 & 23 & 23 & 24 & 29 & 21 & 20 & 9 & 16 & 15 \\
\hline Nc-woodchip & 62 & 5 & 10 & 4 & 16 & 7 & 6 & 4 & 4 & 6 \\
\hline Nc-sawlog & 28 & 6 & 1 & 7 & 3 & 5 & 2 & 0 & 2 & 2 \\
\hline FSC-sawlog & 90 & 12 & 12 & 13 & 10 & 9 & 12 & 5 & 10 & 7 \\
\hline FSC «start» & 63 & 4 & 9 & 11 & 9 & 3 & 5 & 5 & 10 & 7 \\
\hline FSC «exploit〉 & 27 & 8 & 3 & 2 & 1 & 6 & 7 & 0 & 0 & 0 \\
\hline
\end{tabular}

\subsection{Data Treatment and Analyses}

Answers to the open questions were later coded according to thematic categories identified from the answers [103]. Microsoft Excel was used for data management and basic calculations. Minitab 17 (Minitab Inc., State College, PA, USA) and R software (3.5.2 version) were used to establish significant variable interrelationships by using appropriate statistical methods. Bivariate statistical methods included parametric (T-Test, analysis of variance) and nonparametric (Chi-square, Mann-Whitney, and Kruskal-Wallis) tests. Multivariate statistical methods included multivariate linear regression (MLR; including best subsets regression BSR, to select optimal variable combinations), binary (BLR) and ordinal (OLR) logistic regression, and general linear models (GLM). Before analyses the interval data were checked for normal distribution and if necessary, transformed as appropriate (e.g., logarithm, square root, or other transformation). In the Supplementary Materials, we provide a summary of all questionnaire questions, the corresponding primary or coded data, and the statistical results which are outlined and discussed within this paper. The Supplementary Materials also include additional notes on limitations and specifications of the study.

\section{Results and Discussion}

\subsection{The Respondents' Profiles}

The ethnic composition of the 180 respondents differed regionally, as could be expected. In Phú Lộc 67 respondents belonged to the Kinh majority, whereas three in Xuân Lộc Commune were ethnic Bru-Vân Kiều. In Hương Trà all 70 respondents were Kinh. In upland A Lưới, in contrast, only one of the 40 respondents was of Kinh ethnicity; the others identified as Pa Cô $(24)^{5}$, Tà Ôi (7), and Cơ Tu (8). Most respondents were men ( $82 \%$ vs. $18 \%$ women; no differences among districts, ethnicities, or farmer types). The 
respondents were between 28-79 years old, whereby respondents of ethnic minorities were on average younger ( $45 \pm 11$ years) as compared to Kinh respondents (54 \pm 8 ). The respondents' time spent in school ranged from $0-16$ years, with on average a higher education recorded for men (7.9 \pm 3.5 years) vs. women $(5.2 \pm 3.5)$, for Kinh $(7.7 \pm 3.5)$ vs. members of ethnic minority groups $(6.4 \pm 4.1)$, for younger vs. older respondents, and for farmer types in the order of FSC «exploit〉 $(10.3 \pm 3.2)$ vs. FSC «start> $(8.7 \pm 3.2)$ vs. Nc-sawlog $(5.7 \pm 2.7)$ vs. Nc-woodchip (5.3 \pm 3.2$)$. Some respondents $(21 \%$; mostly the better educated and older) stated that they held a leadership and/or honorary position ${ }^{6}$.

Most respondents (89\%) supported at least one (up to seven) dependent person(s) in the household, i.e., either children (on average $2.2 \pm 1.1$ ) or parents $(0.3 \pm 0.5)$. Older and better educated respondents tended to have fewer dependents in their household (mainly fewer children). Furthermore, respondents in Hương Trà (close to Huế City) supported on average fewer dependents $(2.1 \pm 1.3)$ than respondents in the more rural communes of Phú Lộc $(2.7 \pm 1.5)$ and A Lưới $(2.9 \pm 1.2)$. Patterns may be explained by differing opportunities for younger family members to find alternative jobs locally or in nearby cities, and/or social-cultural connections within rural communities $[105,106]$.

\subsection{Establishment of Plantation Forestry: Timing, Facilitative Processes, and Early Opportunities}

According to respondents' answers, the first acacia plantations were established in Phú Lộc and Hương Trà in 1990 (Figure 2). In Phú Lộc most respondents set up their first acacia plantations between 1994-1997 and in 2004 (Lộc Bổn Commune). In Hương Trà plantations were established throughout the 1990s. In A Lưới, in contrast, acacia planting started in 2004, with planting peaks in 2005 and 2010 (Figure 2). In addition to regional differences, the data indicate that older and better educated respondents stated relatively earlier dates of acacia establishment as compared to the younger and lesser educated.

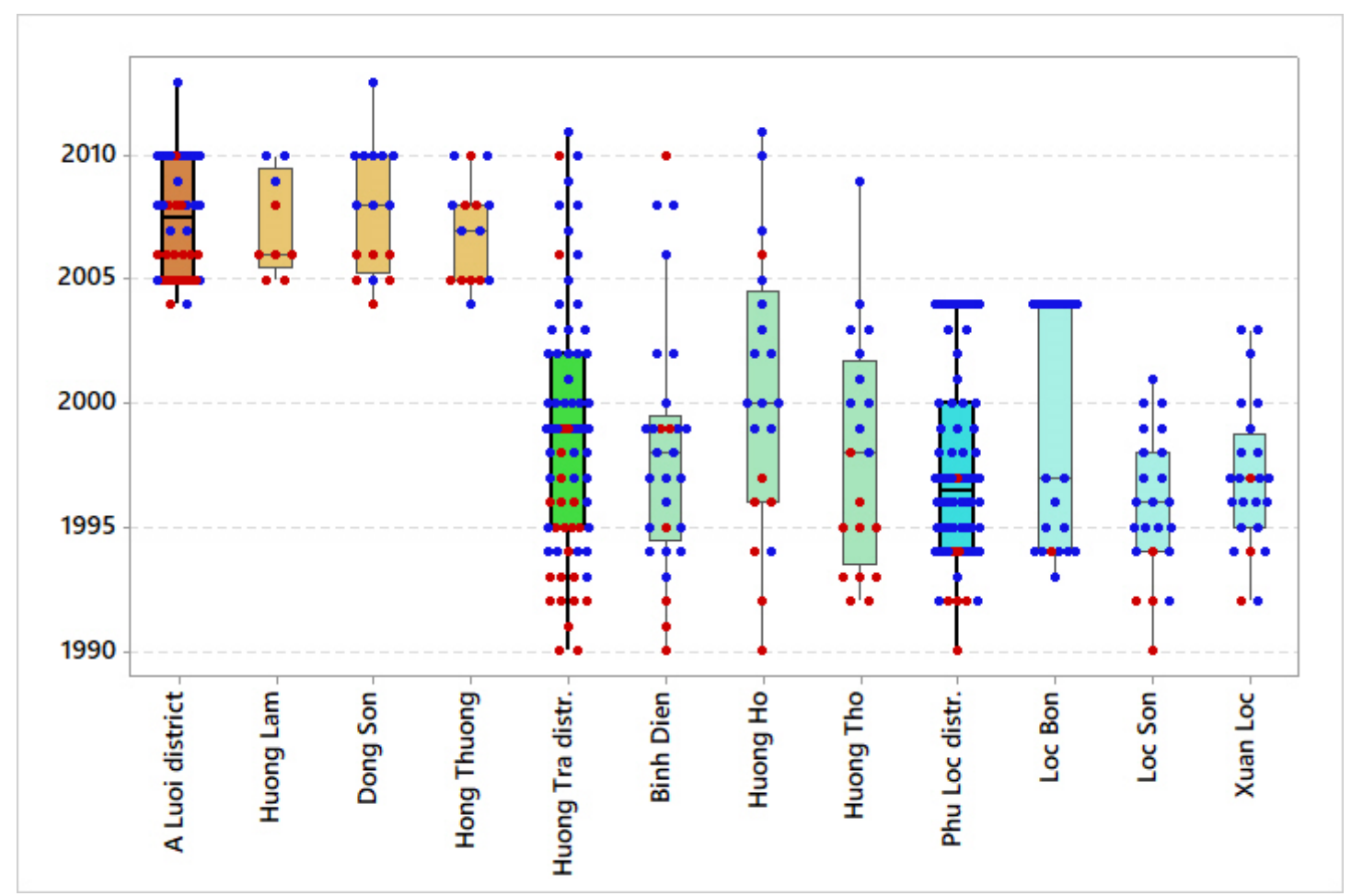

Figure 2. Boxplot graph illustrating the timing (years) of the initial establishment of acacia plantation plots, as indicated by the respondents of the visited communes within each of the three districts. The dots indicate individual data points. Red dots represent the establishment of acacia plots by respondents who had participated in a state-led plantation program; blue dots indicate 'self-motivated' initiation of plantations (this may still have been variously supported by certain development programs). Boxes indicate the 1st, median, and 3rd quartiles; spikes the 0th and 100th percentiles. All data from farmer interviews. 
Farmers with previous experience in tree planting were often pioneers in acacia planting ('early planters'). About half of the respondents in Phú Lộc and Hương Trà (and especially the relatively 'earlier planters') said they had already gained a significant income from eucalypt trees ${ }^{7}$ before planting acacias (Table 2). Nine respondents in Hương Trà $(13 \%)$ and two in Phú Lộc had been gaining an income from rubber plantations. The other respondents (mostly relative 'latecomers' in acacia planting) had apparently not been engaged in tree farming; they had earned their livelihoods mainly from cultivating staple crops such as cassava (44\%; probably on swidden fields, especially in A Lưới), or from other activities (13\%; e.g., collection of wild products; Table 2 ).

Extensive tree planting programs, FLA, and other policy-driven actions starting in the 1990s evidently catalyzed the establishment of acacia plantations-partly in similar ways as in other parts of Vietnam [1,50,54,59,107-109]. When asked about the reasons/incentives to start with planting acacias, a good number of respondents (29\%; especially the relatively 'earlier planters' in A Lưới and Hương Trà; Figure 2) answered that it was because they were directly involved in a tree plantation program. Plantation programs often served an exemplary function $[1,26]$, and this may partly explain why respondents involved in a program were also likely to occupy a leadership position (50\% vs. $23 \%$ of those not involved). Most of the other respondents (61\%; i.e., mostly relative 'latecomers', and many respondents in Phú Lộc) explained that they saw other people planting acacias and then learned from them about the benefits of this plant (Table 2). Respondents who gave this type of answer also tended to be younger and less educated and included disproportionately more women. Some respondents in Phú Lộc (now mostly FSC-farmers) additionally noted specific benefits that apparently convinced them to plant acacias, i.e., $21 \%$ (all previously engaged in planting eucalypts) stated that acacias grew well and improved the quality of the soils (unlike eucalypt trees [110]) ${ }^{8}$ and $14 \%$ said they saw that acacia planting provided good opportunities to earn money (Table 2).

While tree plantation programs served-apart from 'reforestation' - certain demonstration and educational purposes, participation in such a program was not in every case a prerequisite to receive support for acacia planting and management $[1,50]$. Many respondents said they had received some form of help either from a governmental organization (72\%; e.g., a state forest company; $69 \%$ of these respondents had been engaged in a plantation program, and many were 'early planters'), from a NGO (37\%; in Phú Lộc only; mostly the better educated and 'pioneers' who had previously worked on eucalypt plantations), and/or from some other actors (e.g., a private company or international aid agency, or TTH-FOSDA; 9\% respondents in Phú Lộc; Table 2). Some respondents (primarily 'latecomers' and respondents in A Lưới; Table 2) said they had not received any support (8\%) at the time when they started their plantations, or the respondents did not provide information in this regard $(20 \%)$.

When asked about specific programs which provided support, most of the respondents in A Lưới $(90 \%)$ did not list any program. In contrast, many respondents in Hương Trà (69\%) and Phú Lộc (73\%) listed at least one program from which he/she had received support (Table 2), with primarily the 'early planters' and better educated respondents frequently listing more than one program (up to six). Accordingly, the listing of programs differed among farmer types, in the order of FSC «exploit> (on average $3.2 \pm 1.4$ programs) vs. FSC «start> $(1.7 \pm 1.7)$ vs. Nc-sawlog $(0.8 \pm 0.8)$ vs. Nc-woodchip $(0.6 \pm 0.8)$.

Specific state-led programs that were mentioned included the UN's PAM 4304 Program (noted by 33\% of all respondents), the 'Greening the Barren Hills' Program 337 (noted by 33\% in Phú Lộc), the 'Five Million Hectares Reforestation' Program 661 (26\% in Phú Lộc), and the World Bank WB3 'Forest Sector Development Project' (60\% in Hương Trà, 53\% in Phú Lộc; Table 2). Some FSC-sawlog producers also noted that (in more recent years) they had received support through programs led by WWF (40\% FSC members in Hương Trà and 76\% in Phú Lộc, none in A Lưới) or through FSC itself (29\% in Hương Trà and 35\% in Phú Lộc; Table 2). Programs operating at different time periods were characterized by specific objectives and program components, as summarized in Table 3. 
Table 2. Summary of data on the history and involvement in plantation forestry, showing differences among the three study districts (A Lưới, Hương Trà and Phú Lộc) and farmer types (Nc-woodchip, Nc-sawlog, and FSC-sawlog farmers).

\begin{tabular}{|c|c|c|c|c|c|c|c|c|}
\hline \multirow{2}{*}{$\begin{array}{c}\text { All } \downarrow \\
\text { District } \downarrow \downarrow \\
\text { Farmer Type } \downarrow \downarrow \downarrow\end{array}$} & \multicolumn{4}{|c|}{ Pre-Acacia Agricultural Income Sources } & \multicolumn{4}{|c|}{ Catalyzers for / Motivation of Acacia Planting } \\
\hline & $\begin{array}{l}\text { Eucalypt } \\
\text { Groves }\end{array}$ & $\begin{array}{l}\text { Rubber } \\
\text { Groves }\end{array}$ & $\begin{array}{l}\text { Crop } \\
\text { Fields }\end{array}$ & $\begin{array}{l}\text { Other / } \\
\text { No Info }\end{array}$ & $\begin{array}{c}\text { State } \\
\text { Program }\end{array}$ & $\begin{array}{l}\text { Mutual } \\
\text { Learning }\end{array}$ & $\begin{array}{l}\text { "Better } \\
\text { Soils" }\end{array}$ & $\begin{array}{l}\text { "a Good } \\
\text { Income" }\end{array}$ \\
\hline Overall & $37 \%$ & $6 \%$ & $44 \%$ & $13 \%$ & $29 \%$ & $62 \%$ & $9 \%$ & $7 \%$ \\
\hline in Phú Lộc & $54 \%$ & $3 \%$ & $43 \%$ & 0 & $13 \%$ & $70 \%$ & $21 \%$ & $14 \%$ \\
\hline in Hương Trà & $41 \%$ & $13 \%$ & $23 \%$ & $23 \%$ & $34 \%$ & $60 \%$ & $2 \%$ & $3 \%$ \\
\hline in A Lưới & 0 & 0 & $82 \%$ & $18 \%$ & $48 \%$ & $52 \%$ & 0 & 0 \\
\hline Nc-woodchip & $24 \%$ & $5 \%$ & $56 \%$ & $15 \%$ & $18 \%$ & $74 \%$ & $5 \%$ & 0 \\
\hline Nc-sawlog & $46 \%$ & 0 & $46 \%$ & $8 \%$ & $14 \%$ & $82 \%$ & $4 \%$ & 0 \\
\hline FSC-sawlog & $43 \%$ & $9 \%$ & $34 \%$ & $14 \%$ & $41 \%$ & $48 \%$ & $13 \%$ & $13 \%$ \\
\hline All $\downarrow$ & & upport for Aca & cia Planting & & Gov & mental Sup & through $\operatorname{Pr}$ & rams \\
\hline $\begin{array}{c}\text { District } \downarrow \downarrow \\
\text { Farmer Type } \downarrow \downarrow \downarrow\end{array}$ & $\begin{array}{l}\text { Government } \\
\text { Organization }\end{array}$ & $\begin{array}{l}\text { Nongov. } \\
\text { Organiz. }\end{array}$ & Other & $\begin{array}{l}\text { No Help / } \\
\text { No Info }\end{array}$ & $\begin{array}{c}\text { Program } \\
\text { PAM } 4304\end{array}$ & $\begin{array}{c}\text { Program } \\
337\end{array}$ & $\begin{array}{c}\text { Program } \\
661\end{array}$ & $\begin{array}{l}\text { Program } \\
\text { WB3 }\end{array}$ \\
\hline Overall & $69 \%$ & $15 \%$ & $3 \%$ & $28 \%$ & $33 \%$ & $13 \%$ & $10 \%$ & $44 \%$ \\
\hline in Phú Lộc & $79 \%$ & $37 \%$ & $9 \%$ & $12 \%$ & $53 \%$ & $33 \%$ & $26 \%$ & $53 \%$ \\
\hline in Hương Trà & $77 \%$ & $1 \%$ & 0 & $23 \%$ & $27 \%$ & 0 & 0 & $60 \%$ \\
\hline in A Lưới & $38 \%$ & 0 & 0 & $62 \%$ & $8 \%$ & $3 \%$ & 0 & 0 \\
\hline Nc-woodchip & $53 \%$ & 0 & $6 \%$ & $41 \%$ & $18 \%$ & $8 \%$ & $8 \%$ & $23 \%$ \\
\hline Nc-sawlog & $68 \%$ & 0 & 0 & $32 \%$ & $36 \%$ & $7 \%$ & $7 \%$ & $25 \%$ \\
\hline FSC-sawlog & $80 \%$ & $30 \%$ & $2 \%$ & $18 \%$ & $42 \%$ & $19 \%$ & $12 \%$ & $64 \%$ \\
\hline All $\downarrow$ & Other Prog & am Aid & Num & f Support I & grams & Nu & r of Suppor & ems \\
\hline District $\downarrow \downarrow$ & Programs by & Programs & Not & Responde & & Not & Respond & s (\%) \\
\hline Farmer Type $\downarrow \downarrow \downarrow$ & WWF & by FSC & $\underline{0}$ & $\underline{3}$ & 5-6 & $\underline{1}$ & $\underline{2}$ & 5-6 \\
\hline Overall & $25 \%$ & $12 \%$ & 15 & 13 & 7 & 37 & 8 & 22 \\
\hline in Phú Lộc & $40 \%$ & $19 \%$ & 13 & 26 & 19 & 27 & 6 & 36 \\
\hline in Hương Trà & $24 \%$ & $13 \%$ & 20 & 42 & 0 & 33 & 13 & 36 \\
\hline in A Lưới & 0 & 0 & 10 & 0 & 0 & 60 & 5 & 0 \\
\hline Nc-woodchip & 0 & 0 & 21 & 13 & 0 & 55 & 10 & 0 \\
\hline Nc-sawlog & 0 & 0 & 39 & 18 & 0 & 46 & 18 & 0 \\
\hline FSC-sawlog & $50 \%$ & $24 \%$ & 29 & 23 & 14 & 21 & 6 & 56 \\
\hline All $\downarrow$ & Needing a & & pecific Sup & Items (Pro & ed through $P$ & rams) Note & Responder & \\
\hline $\begin{array}{c}\text { District } \downarrow \downarrow \\
\text { Farmer Type } \downarrow \downarrow \downarrow\end{array}$ & $\begin{array}{l}\text { Loan for } \\
\text { Planting }\end{array}$ & $\begin{array}{l}\text { Offering } \\
\text { a Loan }\end{array}$ & $\begin{array}{l}\text { Seedling } \\
\text { Provision }\end{array}$ & $\begin{array}{l}\text { Fertilizer } \\
\text { Provision }\end{array}$ & $\begin{array}{l}\text { Training } \\
\text { Program }\end{array}$ & $\begin{array}{l}\text { Product } \\
\text { Selling }\end{array}$ & $\begin{array}{l}\text { Help to } \\
\text { Certify }\end{array}$ & $\begin{array}{c}\text { Plant } \\
\text { Diseases }\end{array}$ \\
\hline Overall & $76 \%$ & $49 \%$ & $41 \%$ & $18 \%$ & $35 \%$ & $31 \%$ & $29 \%$ & $7 \%$ \\
\hline in Phú Lộc & $81 \%$ & $44 \%$ & $59 \%$ & $21 \%$ & $51 \%$ & $43 \%$ & $47 \%$ & 0 \\
\hline in Hương Trà & $70 \%$ & $67 \%$ & $36 \%$ & $24 \%$ & $36 \%$ & $37 \%$ & $27 \%$ & $19 \%$ \\
\hline in A Lưới & $75 \%$ & $28 \%$ & $18 \%$ & 0 & $5 \%$ & 0 & 0 & 0 \\
\hline Nc-woodchip & $82 \%$ & $31 \%$ & $16 \%$ & 0 & $5 \%$ & 0 & $6 \%$ & 0 \\
\hline Nc-sawlog & $75 \%$ & $32 \%$ & $29 \%$ & 0 & $18 \%$ & 0 & $14 \%$ & 0 \\
\hline FSC-sawlog & $71 \%$ & $68 \%$ & $61 \%$ & $36 \%$ & $61 \%$ & $62 \%$ & $49 \%$ & $14 \%$ \\
\hline All $\downarrow$ & & Iain Reasons to & Continue I & ting Acacias & & $\mathrm{Bu}$ & and Sellin & lots \\
\hline $\begin{array}{c}\text { District } \downarrow \downarrow \\
\text { Farmer Type } \downarrow \downarrow \downarrow\end{array}$ & $\begin{array}{c}\text { "Good } \\
\text { Income" }\end{array}$ & $\begin{array}{l}\text { "Investment } \\
\text { Return" }\end{array}$ & $\begin{array}{l}\text { “Close } \\
\text { Market" }\end{array}$ & $\begin{array}{l}\text { "Easy to } \\
\text { Manage" }\end{array}$ & $\begin{array}{l}\text { "Low In- } \\
\text { vestment" }\end{array}$ & $\begin{array}{l}\text { Sell Plots } \\
\text { of Acacia }\end{array}$ & $\begin{array}{l}\text { Buy Plots } \\
\text { of Acacia }\end{array}$ & $\begin{array}{c}\text { Change } \\
\text { (ha/farmer) }\end{array}$ \\
\hline Overall & $54 \%$ & $9 \%$ & $9 \%$ & $18 \%$ & $9 \%$ & $6 \%$ & $11 \%$ & $0.5 \pm 2.4$ \\
\hline in Phú Lộc & $51 \%$ & $11 \%$ & $13 \%$ & $10 \%$ & $14 \%$ & $1 \%$ & $17 \%$ & $1.12 \pm 3.5$ \\
\hline in Hương Trà & $71 \%$ & $10 \%$ & $10 \%$ & $4 \%$ & $4 \%$ & $11 \%$ & $10 \%$ & $0.15 \pm 1.3$ \\
\hline in A Lưới & $30 \%$ & $5 \%$ & 0 & $55 \%$ & $10 \%$ & $3 \%$ & 0 & $-0.1 \pm 0.3$ \\
\hline Nc-woodchip & $52 \%$ & $16 \%$ & $6 \%$ & $19 \%$ & $6 \%$ & $10 \%$ & $2 \%$ & $-0.1 \pm 0.6$ \\
\hline Nc-sawlog & $36 \%$ & $7 \%$ & $18 \%$ & $7 \%$ & $32 \%$ & $4 \%$ & $4 \%$ & $0.02 \pm 0.4$ \\
\hline FSC-sawlog & $62 \%$ & $6 \%$ & $8 \%$ & $20 \%$ & $4 \%$ & $3 \%$ & $19 \%$ & $1.06 \pm 3.2$ \\
\hline
\end{tabular}

In order to establish an acacia plantation, many farmers needed to overcome financial obstacles. Most respondents (76\%; Table 2; especially 'early planters' and members of ethnic minorities) stated that they took up a loan in order to set up the plantation, whereas 
the others (24\%; primarily well-educated farmers and those previously engaged in rubber plantations) apparently had sufficient savings to start their acacia plantations independently. Of those in need of a loan, $65 \%$ (i.e., $35 \%$ of non-FSC and 78\% of FSC-farmers; Table 2) explicitly noted that they had received a loan through support from a state program, of which $81 \%$ mentioned they had received support from the WB3 Program. The WB3 program supported low interest rates of loans of $0.65 \%$ per month for famers, whereas normally the interest rate at other banks was more than $3 \%$ per month [114].

Table 3. Summary of key data and characteristics of plantation programs listed by the respondents. The table indicates the programs' objectives and items of investment in terms of relatively major $\left({ }^{* * *}\right)$, medium $\left({ }^{* *}\right)$ and minor $\left({ }^{*}\right)$ importance. In some cases, information could not be found from available resources (n.a.).

\begin{tabular}{|c|c|c|c|c|c|c|}
\hline & $\begin{array}{c}\text { Program } \\
\text { PAM } 4304\end{array}$ & $\begin{array}{c}\text { Program } \\
337\end{array}$ & $\begin{array}{c}\text { Program } \\
661\end{array}$ & $\begin{array}{l}\text { Program } \\
\text { WB3 }\end{array}$ & $\begin{array}{l}\text { Programs } \\
\text { by WWF }\end{array}$ & $\begin{array}{c}\text { Programs } \\
\text { by FSC }\end{array}$ \\
\hline Implementation Time ${ }^{1}$ & 1992-2000 & 1993-1998 & 1998-2010 & $2005-2014$ & 2015-2020 & 2016-now \\
\hline Project Volume in US\$ ${ }^{1}$ & 20.3 million & 213 million & $>2000$ million & 4.7 million & n.a. & 0.53 million \\
\hline Funding Agencies ${ }^{2}$ & WFP & GoV, WB & GoV, WB & WB, JICA & IK, WWF & WWF, SP, USAID \\
\hline Implementing Agencies ${ }^{2}$ & $\begin{array}{l}\text { DARD, SFEs } \\
\text { (n.a.) }\end{array}$ & DARD, SFEs & DARD, SFEs & DARD, SFEs & WWF & $\begin{array}{l}\text { WWF }^{3}, \text { SP, } \\
\text { USAID }\end{array}$ \\
\hline Afforestation Area in ha ${ }^{1}$ & n.a. & $\sim 0.4$ mil. (?) & $\sim 2.45$ mil. & $12^{\prime} 800$ ha & 5142 ha & 5172 ha \\
\hline Number of Households ${ }^{1}$ & n.a. & n.a. & $\sim 1.2$ mil. hh & 8750 hh & $1000 \mathrm{hh}$ & $1028 \mathrm{hh}$ \\
\hline Objective: FLA & yes $(* * *)$ & yes $(* *)$ & yes $(* * *)$ & yes $(* *)$ & no & no \\
\hline Objective: Tree Planting & yes $(* * *)$ & $\operatorname{yes}(* * *)$ & $\operatorname{yes}(* * *)$ & yes $(* * *)$ & no & yes $(* * *)$ \\
\hline Objective: Certification & no & no & no & yes $(* *)$ & yes $(* *)$ & yes $(* * *)$ \\
\hline Object.: Forest Protection & n.a. & yes $(* * *)$ & yes $(* * *)$ & $(\mathrm{no})^{4}$ & yes $(* * *)$ & yes $(* * *)$ \\
\hline Loans Provided & yes $(*)$ & yes $(* * *)$ & yes $(* * *)$ & yes $(* * *)$ & no & no \\
\hline Tree Nurseries & yes $(* *)$ & yes $(* * *)$ & yes $(* * *)$ & yes $(* *)$ & yes $(* *)$ & yes $\left({ }^{* * *}\right)^{5}$ \\
\hline Fertilizer Provided & yes $(* *)$ & no & no & n.a. & no & no \\
\hline Training / Information & yes $(*)$ & yes $(* *)$ & yes $\left({ }^{* *}\right)$ & yes $\left({ }^{* *}\right)$ & yes $(* * *)$ & yes $\left({ }^{* * *}\right)$ \\
\hline Product Selling & no & yes $(* *)$ & n.a. & yes $(* *)$ & no & yes $(* * *)$ \\
\hline Product Certification & no & no & yes $(*)$ & yes $(* *)$ & no & yes $(* * *)$ \\
\hline Other & n.a. & yes $(* *)^{6}$ & yes $(* *)^{6}$ & yes $(* *)^{6}$ & no & yes $(* *)^{7}$ \\
\hline
\end{tabular}

${ }^{1}$ The implementation time, project volume, afforestation area, and number of households refers to all of Vietnam, except for WWF and FSC programs, which refer to TTHP only. ${ }^{2}$ Abbreviations are WFP (World Food Programme), GoV (Government of Vietnam), WB (World Bank), JICA (Japan International Development Agency), IK (IKEA Group retailers, Sweden), SP (Scansia Pacific Co., Ltd., Dong Nai, Vietnam), WWF (World Wildlife Fund), USAID (United States Agency for International Development), DARD (Vietnam Department of Agriculture and Rural Development), SFEs (state forest enterprises). ${ }^{3}$ This includes the partner organization TTH-FOSDA (Thua Thien Hue Forest Owners Sustainable Development Association). ${ }^{4}$ The 'protection of natural forest' was noted as a benefit of plantation development. ${ }^{5}$ This included providing native trees to households participating in FSC certified afforestation. ${ }^{6}$ Building of forest roads and fire protection. ${ }^{7}$ Support of thinning activities. References: $[1,23,26,43,49,51,102,114]$.

Many programs also offered aid to overcome technical/logistic obstacles of plantation establishment/management, and support in wood product selling/marketing (Table 2). Many respondents (41\%; mostly FSC-sawlog producers) noted that acacia seedlings were provided through governmental support programs from nurseries (including through Program 327 and PAM 4304, especially in the case of 'early planters'), as well as through programs led by NGOs, notably WWF. Some FSC-farmers in Phú Lộc (41\%) and Hương Trà $(55 \%)$ had also received fertilizers, provided through programs led by the state and by WWF. A third of the respondents (35\%; mostly FSC-farmers in Phú Lộc; Table 2) mentioned that they received specific trainings (most commonly in tree plantation techniques), mainly (as indicated by the data) through the WB3 Program and/or programs directed through WWF and FSC. Many FSC-farmers in Hương Trà ( $84 \%)$ and Phú Lộc ( $81 \%)$ noted that programs (mainly Program 327 and WB3, and programs by WWF) also provided support for selling the wood products from the plantations. Similarly, respondents (85\% FSC members and 15\% non-members) in Hương Trà and Phú Lộc (27-47\%) mentioned that programs (mainly FSC programs and WB3) provided training and support for the certification of wood products from the plantations (Table 2). Finally, thirteen FSC-farmers in Hương Trà noted that officers from extension programs came to investigate root diseases (as of yet unknown) which they had observed affecting trees in their plantations. Overall, respondents listed more items of support if they had received support from more than one program, in 
particular from the WB3 Program, and/or-in the case of FSC members-programs by WWF and FSC. Generally, relatively fewer items were listed by women and by respondents who had set up their plantations autonomously (i.e., through 'learning from others'). Respondents who are now FSC members tended to list significantly more support items (and especially in Hương Trà and Phú Lộc) than those who are not (yet) FSC members (Table 2).

\subsection{Motivations for Acacia Planting, and Ownership Transfers of Plantation Lands}

When asked about the main reasons that kept them motivated to continue planting acacias on their plots until today, the opportunity to earn good money was spontaneously mentioned by a majority of respondents $(54 \%)$, notably by respondents of the Kinh majority (and especially the better educated) in Hương Trà and Phú Lộc. Some respondents were more specific, noting the advantages of a relatively fast return of investment from acacia plantations $(9 \%)$ or the presence of a local and relatively stable market for acacia wood products ( $9 \%$; this was not noted in more remote A Lưới; Table 2). Others ( $27 \%$ overall) were more inclined to spontaneously point out the practicality of acacia plantation management. Mostly members of ethnic minorities (55\% of respondents in A Lưới; Table 2) noted that acacia plantations are relatively 'easy to manage, with simple techniques'. Some respondents ( $9 \%$ overall) remarked that the investments for planting acacias (in terms of money and labor) are relatively low; this answer was relatively more often given by women ( $22 \%$ vs. $7 \%$ of the men).

Until 2018 ownerships of the initially established acacia plots were apparently fairly stable overall. Relatively few farmers stated they had either sold some acacia plots (10 farmers, $6 \%$ ) or bought additional plots (19 farmers, 11\%; Table 2). Most of the 'sellers' were Nc-woodchip producers in Hương Trà (six farmers selling acacia plots, two selling rubber plots), and most stated they had not received any support from any programs (eight vs. two who had received support). Land sales mostly took place in between 2010 and 2015 and involved plots ranging in size from 1-3 hectares (average $1.7 \pm 0.8$ ha). All the farmers buying plots either lived in Phú Lộc $(17 \%)$ or Hương Trà $(10 \%)$, were mostly FSC members and of younger age, and had likely received support from NGOs, especially WWF. Most of the plot acquisitions (14, 74\%) took place in 2014 and 2015 and involved plots ranging in size from 1-19.5 hectares (average $5.5 \pm 4.9$ ha). Overall, the plantation area of farmers in Phú Lộc (especially that of FSC «exploit` respondents) had been increasing (on average by over one hectare), whereas it had been relatively stable or slightly decreasing in Hương Trà and A Lưới (Table 2).

\subsection{Plantation Development: Local Terrain, Land Conversion, and Antecedent Land Uses}

Acacia planting and corresponding establishment of plot tenure was spatially influenced by terrain as well as preceding locally adapted land uses and livelihoods. Data from respondents' answers reflects the reality that acacia plots in upland A Lưới were generally set up within more steeply sloping terrain (i.e., $78 \%$ of all plantation areas were appraised at $>10^{\circ}$ slope inclination) as compared to the plots in Hương Trà (43\%) and Phú Lộc (36\%) districts (Table 4).

Most of the plots were initially established by clearing 'bushland' (i.e., $75 \%$ of plantations by ownership and $83 \%$ by total cover converted to plantations; Table 4 ). Bushland vegetation was particularly predominant in Hương Trà ( $97 \%$ by converted cover) -i.e., a region where forests had been extensively destroyed during and after the war (Section 2.1). Most farmers who had participated in plantation programs (which focused on bushcovered 'bare hills') and/or already had experience with eucalypt plantations established acacia stands in bushland areas. 'Bare hills' could vary widely in terms of vegetation cover from highly degraded 'scrublands' to dense 'bushlands', which possibly represented earlysuccession regenerating forests $[1,25]$. Such bushlands could be quite species-rich [115] and were often used by poor people and often by women [1,43]. In our study, only a quarter of the respondents appraised the bushlands as providing support of minor (24\%) or moderate 
(1\%) importance for their livelihoods, for uses such as the collection of firewood (88\%), wood products for other uses (27\%), and wild food products (21\%; Table 4).

Table 4. Summary of data on the plantation terrain and pre-acacia land cover/use, showing differences among the three study districts and farmer types.

\begin{tabular}{|c|c|c|c|c|c|c|c|c|}
\hline \multirow{3}{*}{$\begin{array}{c}\text { All } \downarrow \\
\text { District } \downarrow \downarrow \\
\text { Farmer Type } \downarrow \downarrow \downarrow\end{array}$} & \multirow{2}{*}{\multicolumn{4}{|c|}{$\begin{array}{c}\text { Plantation Terrain: Percentage Cover in Relative Steepness } \\
\text { Category (Inclination in Degrees) }\end{array}$}} & \multicolumn{4}{|c|}{ Pre-Acacia Land Cover (Percentage Area) } \\
\hline & & & & & \multirow{2}{*}{ Bushland } & \multirow{2}{*}{ Crop Fields } & \multirow{2}{*}{$\begin{array}{l}\text { Bare } \\
\text { Land }\end{array}$} & \multirow{2}{*}{$\begin{array}{c}\text { Natural } \\
\text { Forest }\end{array}$} \\
\hline & $<4^{\circ}$ & $\sim 4^{\circ}-10^{\circ}$ & $\sim 10^{\circ}-30^{\circ}$ & $>30^{\circ}$ & & & & \\
\hline Overall & $11 \%$ & $45 \%$ & $41 \%$ & $3 \%$ & $83 \%$ & $13 \%$ & $1 \%$ & $3 \%$ \\
\hline in Phú Lộc & $13 \%$ & $51 \%$ & $32 \%$ & $4 \%$ & $78 \%$ & $20 \%$ & $2 \%$ & 0 \\
\hline in Hương Trà & $14 \%$ & $43 \%$ & $42 \%$ & $1 \%$ & $97 \%$ & $2 \%$ & $1 \%$ & 0 \\
\hline in A Lưới & 0 & $22 \%$ & $74 \%$ & $4 \%$ & $64 \%$ & $12 \%$ & 0 & $24 \%$ \\
\hline Nc-woodchip & $12 \%$ & $41 \%$ & $45 \%$ & $2 \%$ & $65 \%$ & $17 \%$ & $5 \%$ & $13 \%$ \\
\hline Nc-sawlog & $11 \%$ & $37 \%$ & $46 \%$ & $6 \%$ & $77 \%$ & $18 \%$ & 0 & $5 \%$ \\
\hline FSC-sawlog & $11 \%$ & $46 \%$ & $40 \%$ & $3 \%$ & $86 \%$ & $12 \%$ & $1 \%$ & $1 \%$ \\
\hline \multicolumn{2}{|c|}{ Pre-Acacia Land Cover } & \multicolumn{4}{|c|}{ Importance of Pre-Acacia Livelihood Support } & \multicolumn{3}{|c|}{ Pre-Acacia Land Assets for Livelihoods } \\
\hline Type & Relative Cover & None & Minor & Moderate & Significant & Wood & Firewood & Food \\
\hline Weighted Sum & $(100 \%)$ & $66 \%$ & $31 \%$ & $4 \%$ & $0.4 \%$ & $25 \%$ & $77 \%$ & $32 \%$ \\
\hline Bushland & $83 \%$ & $76 \%$ & $24 \%$ & $1 \%$ & 0 & $27 \%$ & $88 \%$ & $21 \%$ \\
\hline Crop Fields & $13 \%$ & $8 \%$ & $79 \%$ & $13 \%$ & 0 & 0 & $5 \%$ & $100 \%$ \\
\hline Bare Land & $1 \%$ & $100 \%$ & 0 & 0 & 0 & 0 & 0 & 0 \\
\hline Natural Forest & $3 \%$ & $20 \%$ & $27 \%$ & $40 \%$ & $13 \%$ & $92 \%$ & $100 \%$ & $67 \%$ \\
\hline
\end{tabular}

Some farmers, mostly in Phú Lộc (27\%; 4\% in other districts), had established their plantations on 'agricultural lands', used for the production of staple foods $(100 \%)$ and sometimes firewood (5\%). These lands were mainly on sloping terrain and probably of marginal productivity, and thus more likely to be abandoned. Indeed, respondents appraised these lands as providing no support $(8 \%)$, or only support of minor $(79 \%)$ or moderate (13\%) importance for their livelihoods (Table 4). Five farmers in Phú Lộc and one in Hương Trà had established their plantations on 'bare lands', sites perhaps previously degraded by mining or army camps $[18,25]$.

In A Lưới 15 plantations (37\%; $24 \%$ of total current plantation cover) were notedmostly by Nc-woodchip respondents-to have been established by converting 'natural forest' to 'planted forest'. A Lưới Valley is spatially confined by forested mountains and is now relatively densely populated (Section 2.1.), and abandoned swiddens have often regrown to vegetation which may now be described as secondary 'forest' rather than just 'bushland' [116,117]. Conversion to 'new forests' on former swidden lands may be seen as legitimate customary land use-even if 'deforestation' of 'rainforest' may now be officially 'illegal' $[60,118]$. Three of these respondents $(20 \%)$ stated they had not used these 'forests' to support their livelihoods, but twelve appraised the 'forests' as previously providing support of either minor $(27 \%)$, moderate $(40 \%)$, or significant $(13 \%)$ importance for their livelihoods, for uses such as the collection of firewood (100\% of previous users), timber and other wood products (92\%) and wild foods (67\%; Table 4$)$.

\subsection{Overview of Tree Farmers' Plantation Land Assets in 2018 and in Relation to FSC Membership}

In 2018 there were significant differences among the four farmer types with regard to the number of plantation plots and-correspondingly-the plantation areas managed (Table 5). The generally smaller average plantation area managed by Nc-woodchip farmers did not differ significantly among the three districts; similarly, the (larger) average area managed by Nc-sawlog farmers showed few differences between uplands and lowland districts (Figure 3). In contrast, FSC-sawlog producers (and particularly FSC «exploit> respondents) in Phú Lộc managed significantly larger plantation areas than FSC-sawlog producers in Hương Trà or A Lưới (Figure 3). 
Table 5. Summary of data on plantation and other agricultural land assets, and on plantation management practices and techniques, showing differences among the three study districts and farmer types.

\begin{tabular}{|c|c|c|c|c|c|c|c|c|}
\hline \multirow{2}{*}{$\begin{array}{c}\text { All } \downarrow \\
\text { District } \downarrow \downarrow \\
\text { Farmer Type } \downarrow \downarrow \downarrow\end{array}$} & \multicolumn{3}{|c|}{ Acacia Plantation Land Assets } & \multicolumn{5}{|c|}{ Land Assets by Product Type, Certification, Ownership } \\
\hline & $\begin{array}{l}\text { Number } \\
\text { of Plots }\end{array}$ & $\begin{array}{l}\text { Mean Plot } \\
\text { Size (ha) }\end{array}$ & $\begin{array}{c}\text { Mean Total } \\
\text { Area (ha) }\end{array}$ & $\begin{array}{l}\text { Woodchip } \\
\text { (ha) }\end{array}$ & $\begin{array}{l}\text { Co-Owned } \\
\text { Chip (ha) }\end{array}$ & $\begin{array}{c}\text { Sawlog } \\
\text { Area (ha) }\end{array}$ & $\begin{array}{l}\text { Sawlog } \\
\text { FSC (ha) }\end{array}$ & $\begin{array}{l}\text { Exploited } \\
\text { FSC (ha) }\end{array}$ \\
\hline Overall & $2.4 \pm 1.3$ & $2.1 \pm 1.5$ & $5.8 \pm 7.1$ & $2.7 \pm 4.0$ & $0.5 \pm 2.0$ & $3.1 \pm 4.9$ & $2.3 \pm 3.9$ & $1.0 \pm 3.5$ \\
\hline in Phú Lộc & $2.8 \pm 1.5$ & $2.4 \pm 1.8$ & $8.1 \pm 9.9$ & $3.9 \pm 5.6$ & $1.0 \pm 3.0$ & $4.2 \pm 0.8$ & $2.7 \pm 5.0$ & $1.6 \pm 4.8$ \\
\hline in Hương Trà & $2.3 \pm 1.3$ & $1.9 \pm 1.0$ & $4.8 \pm 4.1$ & $2.3 \pm 2.2$ & $0.3 \pm 1.5$ & $2.5 \pm 0.7$ & $2.1 \pm 3.4$ & $1.1 \pm 2.9$ \\
\hline in A Lưới & $1.7 \pm 0.8$ & $2.1 \pm 1.8$ & $3.4 \pm 2.8$ & $1.3 \pm 1.7$ & 0 & $2.0 \pm 0.6$ & $1.7 \pm 2.5$ & 0 \\
\hline Nc-woodchip & $1.4 \pm 0.6$ & $1.3 \pm 0.6$ & $1.8 \pm 1.5$ & $1.8 \pm 1.5$ & 0 & na & na & na \\
\hline Nc-sawlog & $2.1 \pm 0.7$ & $1.9 \pm 0.7$ & $4.1 \pm 2.0$ & $2.2 \pm 1.8$ & 0 & $1.9 \pm 1.5$ & na & na \\
\hline FSC-sawlog & $3.1 \pm 1.4$ & $2.8 \pm 1.8$ & $9.1 \pm 8.7$ & $3.5 \pm 5.3$ & $1.1 \pm 3.0$ & $5.5 \pm 5.8$ & $4.5 \pm 4.6$ & $2.1 \pm 4.8$ \\
\hline All $\downarrow$ & \multicolumn{4}{|c|}{ Acacia Types Planted, Propagation Techniques } & \multicolumn{2}{|c|}{ Rotation Cycle (years) } & \multicolumn{2}{|c|}{ Cassava Intercrops } \\
\hline $\begin{array}{c}\text { District } \downarrow \downarrow \\
\text { Farmer Type } \downarrow \downarrow \downarrow\end{array}$ & $\begin{array}{l}\text { Hybrid } \\
\text { Acacia }\end{array}$ & $\begin{array}{c}\text { Acacia } \\
\text { mangium }\end{array}$ & $\begin{array}{c}\text { Hybrid + } \\
\text { Mangium }\end{array}$ & $\begin{array}{l}\text { "Seeds > } \\
\text { Cuttings" }\end{array}$ & $\begin{array}{l}\text { Woodchip } \\
\text { Plots }\end{array}$ & $\begin{array}{l}\text { Sawlog } \\
\text { Plots }\end{array}$ & $\begin{array}{l}\text { Planting } \\
\text { Intercrop }\end{array}$ & $\begin{array}{l}\text { "Intercrop > } \\
\text { No Intercr." }\end{array}$ \\
\hline Overall & $75 \%$ & $14 \%$ & $11 \%$ & $31 \%$ & $4.4 \pm 0.5$ & $6.8 \pm 0.8$ & $18 \%$ & $14 \%$ \\
\hline in Phú Lộc & $89 \%$ & 0 & $11 \%$ & $43 \%$ & $4.3 \pm 0.5$ & $6.6 \pm 0.7$ & $13 \%$ & $16 \%$ \\
\hline in Hương Trà & $94 \%$ & 0 & $6 \%$ & $36 \%$ & $4.3 \pm 0.5$ & $6.7 \pm 0.7$ & $4 \%$ & $20 \%$ \\
\hline in A Lưới & $20 \%$ & $62 \%$ & $18 \%$ & $0 \%$ & $5.1 \pm 0.2$ & $7.6 \pm 0.6$ & $50 \%$ & $2 \%$ \\
\hline Nc-woodchip & $85 \%$ & $3 \%$ & $11 \%$ & $24 \%$ & $4.5 \pm 0.6$ & na & $23 \%$ & $16 \%$ \\
\hline Nc-sawlog & $86 \%$ & $7 \%$ & $7 \%$ & $21 \%$ & $4.4 \pm 0.5$ & $5.8 \pm 0.5$ & $14 \%$ & $4 \%$ \\
\hline FSC-sawlog & $64 \%$ & $18 \%$ & $18 \%$ & $38 \%$ & $4.3 \pm 0.5$ & $7.2 \pm 0.6$ & $16 \%$ & $18 \%$ \\
\hline All $\downarrow$ & Collect & \multicolumn{3}{|c|}{ Wage Earning and Labor Hiring } & \multicolumn{4}{|c|}{ Acacia Stand and Plot Management } \\
\hline $\begin{array}{c}\text { District } \downarrow \downarrow \\
\text { Farmer Type } \downarrow \downarrow \downarrow\end{array}$ & $\begin{array}{l}\text { Firewood } \\
\text { on Plots }\end{array}$ & $\begin{array}{l}\text { Wage } \\
\text { Earning }\end{array}$ & $\begin{array}{l}\text { Hired by } \\
\text { Others }\end{array}$ & $\begin{array}{l}\text { Hiring } \\
\text { Others }\end{array}$ & $\begin{array}{c}\text { Stand } \\
\text { Thinning }\end{array}$ & $\begin{array}{c}\text { Stand } \\
\text { Pruning }\end{array}$ & $\begin{array}{c}\text { Plot } \\
\text { Weeding }\end{array}$ & $\begin{array}{l}\text { "No Weed. > } \\
\text { Weeding" }\end{array}$ \\
\hline Overall & $12 \%$ & $59 \%$ & $57 \%$ & $85 \%$ & $36 \%$ & $89 \%$ & $88 \%$ & $28 \%$ \\
\hline in Phú Lộc & $17 \%$ & $54 \%$ & $56 \%$ & $77 \%$ & $53 \%$ & $100 \%$ & $89 \%$ & $44 \%$ \\
\hline in Hương Trà & $13 \%$ & $57 \%$ & $49 \%$ & $93 \%$ & $29 \%$ & $90 \%$ & $99 \%$ & $20 \%$ \\
\hline in A Lưới & $2 \%$ & $73 \%$ & $75 \%$ & $85 \%$ & $18 \%$ & $68 \%$ & $70 \%$ & $13 \%$ \\
\hline Nc-woodchip & $32 \%$ & $97 \%$ & $87 \%$ & $77 \%$ & 0 & $79 \%$ & $85 \%$ & $31 \%$ \\
\hline Nc-sawlog & $7 \%$ & $82 \%$ & $61 \%$ & $89 \%$ & 0 & $96 \%$ & $86 \%$ & $32 \%$ \\
\hline FSC-sawlog & 0 & $27 \%$ & $36 \%$ & $89 \%$ & $71 \%$ & $95 \%$ & $91 \%$ & $30 \%$ \\
\hline
\end{tabular}

${ }^{1}$ Includes 'stand thinning already applied in the past' as well as 'intent to apply stand thinning on plantations'.

Most of the respondents (91\%) owned all of their managed plantation areas. Some FSC members in Hương Trà $(13 \%)$ and Phú Lộc (27\%), however, managed (i.e., de facto 'co-owned') some plots collaboratively with other owners of 'forestland' (on average $36 \% \pm 15 \%$ of their managed plot areas). In those collaborative arrangements, the respondents usually provided necessary key investments to set up and tend the plantations (e.g., seedlings, fertilizer, labor), whereas the profits from tree harvesting were shared among the co-operating partners. Co-owned plots were all used for Nc-woodchip production (Table 5).

Owners of large plantations (i.e., usually sawlog-producers, in particular FSC members) were typically relatively well educated and connected to forest state organizations and other political actors. These better-placed plantation owners often noted specific training support which they had received from development programs. FSC-sawlog producers in particular noted various support received from programs, with FSC «exploit respondents often referring to WWF. In contrast, Nc-woodchip farmers often owned relatively larger plantations if they had participated in a government-led plantation program (e.g., Program 337) and/or owned some rubber plantations besides their acacia plots.

A minimum tree plantation area of only 0.3 hectares would suffice for permission to participate in an FSC Association [80]; yet, in reality a 'critical mass' of land was evidently needed by farmers to set aside plots for long-rotation sawlog production (cf. Figure 3). This noted, the data indicate that the 'acacia plantation boom' did not transition to a 'sawlog boom' solely on a basis of accumulated land tenure. Only a third of the sawlog producers (31\%; 34\% of FSC-sawlog producers) used all of their plantations for sawlog 
production. The others (69\%) used on average around half $(48 \% \pm 18 \%)$ of their plantation area for sawlogs, keeping the rest for woodchip production (cf. Table 5). The percentage of land used for sawlog production was in fact uncorrelated with plantation area but tended to be higher if the farmers occupied a leadership position or had received training through diverse programs, especially as an FSC member. In addition to a certain land resource 'threshold', social and political capital and incentives were thus not unimportant in explaining the farmers' enterprise in sawlog production.

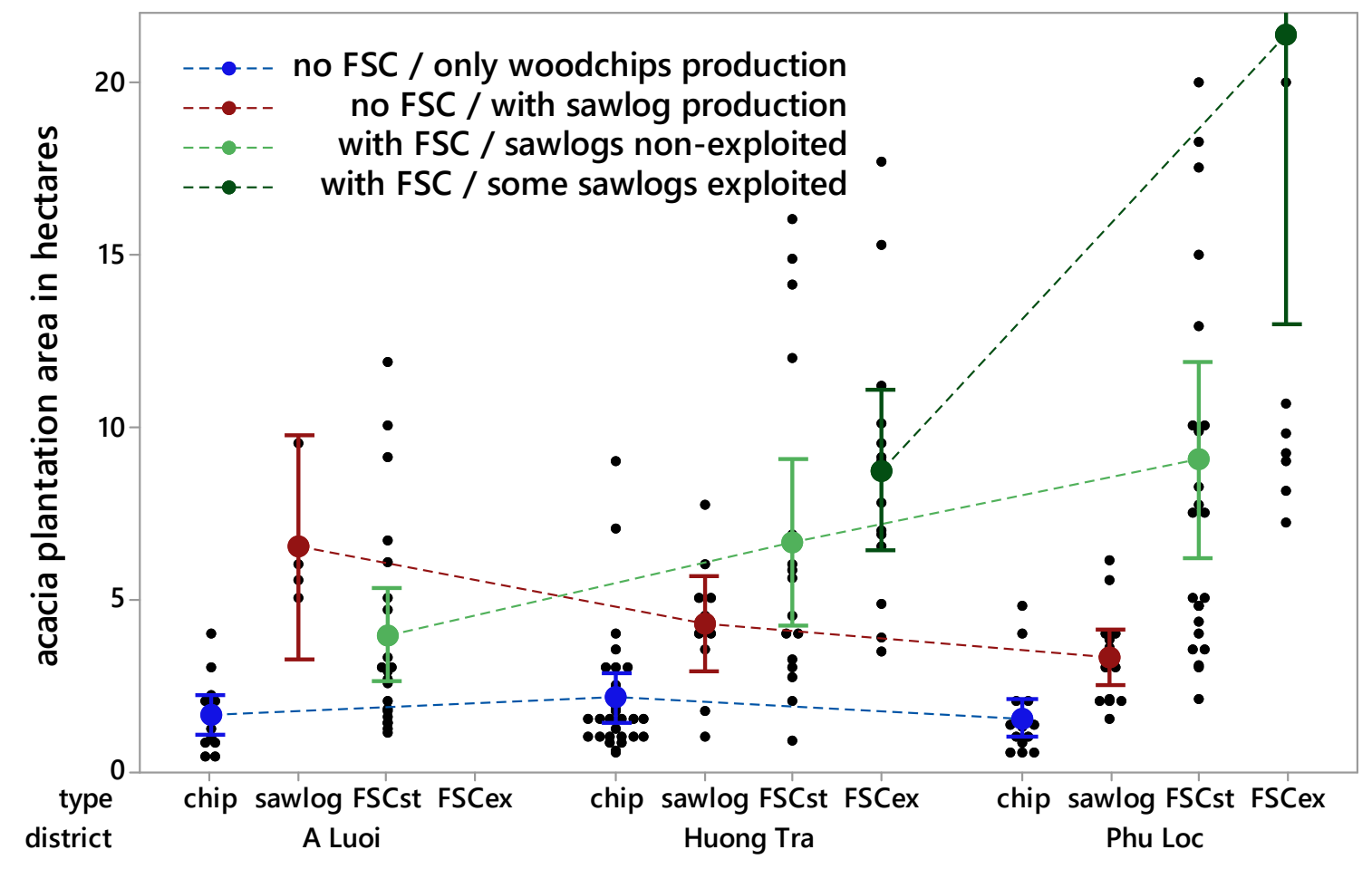

Figure 3. Interval plot showing the differences in acacia plantation areas (in hectares) cultivated by the 90 members of the FSC certification program (all producing sawlogs; 27 with FSC-sawlogs already exploited [FSCex] and 63 who just had started with FSC [FSCst]) and 90 non-members (28 producing sawlogs, and 62 producing woodchips only [chips]) among the three districts. The black dots show the individual data. The plantation areas of seven FSC-farmers at Phú Lộc were larger than 18 hectares (i.e., beyond indicated Y-scale), with a maximum at 46 hectares. Note that some plantations of sawlog producers also served to produce woodchips. Spikes indicate the mean and $95 \%$ confidence interval. All data from farmer interviews.

Similarly, percentages of plantation areas covered by FSC certification were varied. Eighty percent of the FSC members (and 78\% of FSC «exploit respondents) had all of their sawlog-plantation plots certified under FSC, whereas the others had on average only $61 \% \pm 25 \%$ of their sawlog plots FSC certified $(46 \% \pm 17 \%$ for FSC <exploit respondents; cf. Table 5). Notably, even though FSC-farmers in Phú Lộc managed the largest plantation areas, percentagewise FSC coverage tended to be lower in Phú Lộc (64\%) as compared to Hương Trà (84\%) and A Lưới (85\%).

The data thus indicate that lower-grade woodchip production was still a preferred choice by most tree farmers. In accordance with findings elsewhere [5,22,26,75], it may be inferred that this was because of easier plantation management for short-rotation acacia, including the fast (and still comparatively high) economic returns with lesser risks (e.g., storm impacts, plant diseases, future economic uncertainties) and lower administrative costs (e.g., for acceding to membership in an FSC Association). Long-rotation acacia may eventually be more lucrative $[5,6,57,101,119,120]$; yet, the necessary 'innovation space' for 
sawlog production (with associated investments and safeguards) was still mostly exclusive to politically well-connected tree farmers with large landholdings.

\subsection{Configurations of Tree Farmers' Plantation Land Assets: Spatial-Temporal Development Factors}

Plantation land tenure did not develop in uniform ways but favored better-off and/or socio-politically better-connected households from the start [26,43,53,121-123]. Figure 4 shows the chronology of plantation development, set in relation to the respondents' plantation assets in 2018. FSC-sawlog producers (and especially FSC «exploit» respondents) were more likely to have started acacia planting at an early stage as compared to Nc-sawlogproducers. At Phú Lộc all FSC «exploit〉 respondents (with large plantations) had started in acacia forestry between 1990 and 1997, whereas several FSC «start〉 respondents established still relatively large plantations at later dates up until 2004. At Hương Trà plantations were still established until 2010 by respondents with much land and FSC membership in 2018. In contrast, all non-FSC-farmers starting early established comparatively smaller plantation areas. With continuing time, the plantation areas tended to become increasingly smaller for 'newcomers' in the acacia woodchip business. This points to a reduction in the available land that could be claimed with plantations, especially in the case of lesser established and less resourceful farmers.

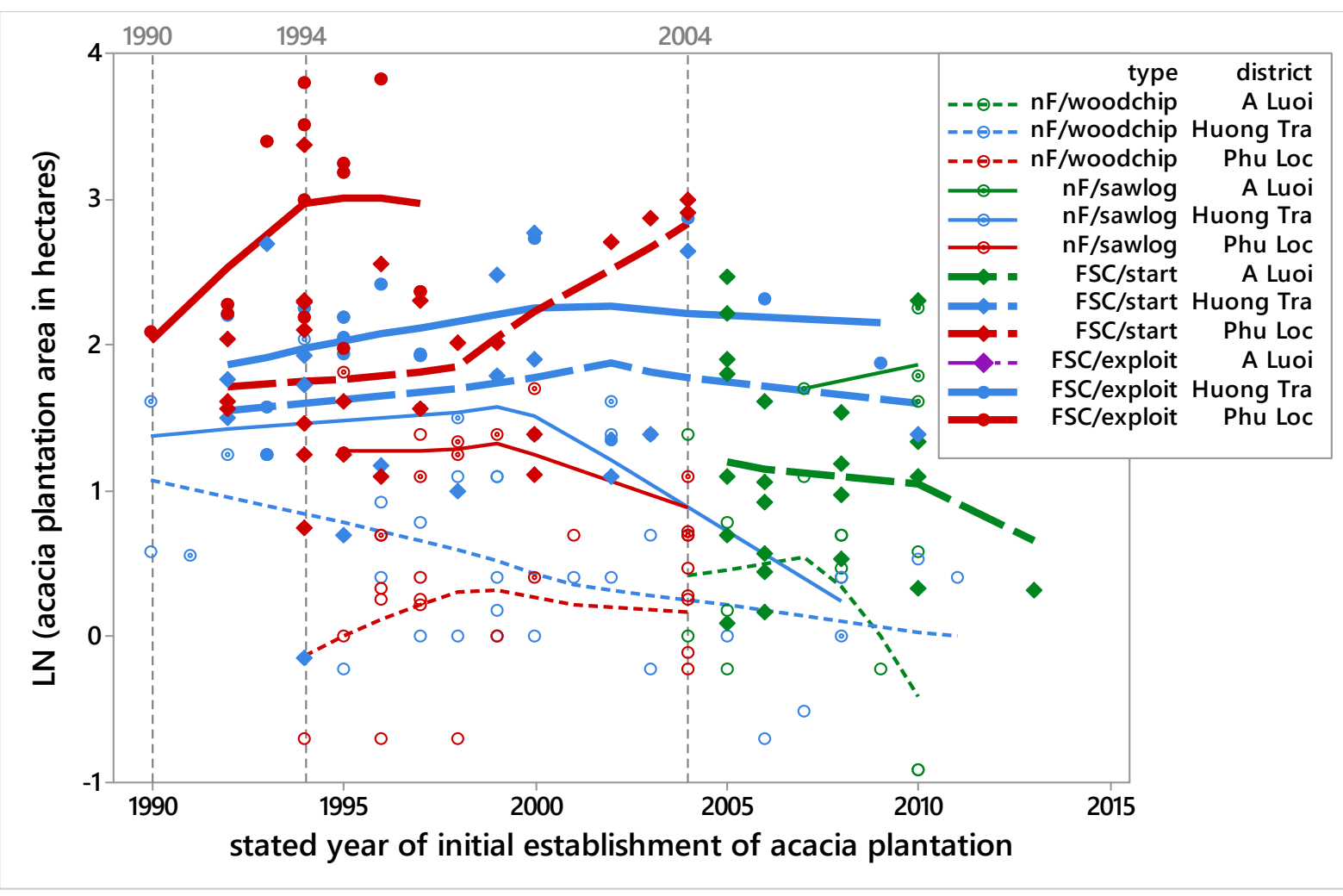

Figure 4. Tree farmers' plantation land assets (by tree farmer type and district) set in relation to the time when the farmers set up their first plantations. The lines indicate a LOWESS smoother fit (smoothing degree 0.5, steps 2). All data from farmer interviews.

Figure 5 illustrates the spatial distribution of acacia plots owned by Nc- and FSCfarmers in 2018. Within A Lưới Valley (confined by steep terrain), acacia plots were mostly located at distances of $\sim 1-4$ kilometers from the respondents' homesteads. There were no significant differences between Nc- and FSC-farmers in A Lưới, but more distant plots tended to be located on steeper terrain. The patterns were partly similar in the plains/hills of Phú Lộc (delimited by the coast and hills/mountains). Here many farmers owned acacia woodlots nearby their homesteads, but several well-established FSC-farmers (and four Nc-farmers) owned plots located at $>4 \mathrm{~km}$ distance, some even in other districts at 
$\sim 20-30 \mathrm{~km}$ distance. Within the less spatially confined undulating hilly former 'frontier' landscape of Hương Trà, both Nc- and FSC-farmers owned plots in relatively distant locations (maximally $\sim 10 \mathrm{~km}$ ), but there was a differentiation with regard to terrain. Ncfarmers usually owned some plots close to their homesteads in relatively even terrain; additional plots in more distant locations were mostly located on steeper terrain. In contrast, FSC-farmers owned many plots located in distant locations in relatively even terrain. In summary, FSC-farmers in Phú Lộc and A Lưới (many had been engaged in initial plantation programs, had received substantial extension support, and/or had previous experience in eucalypt planting) were not only early to set up plantations, but were often able to obtain entitlements for sizeable and comparatively valuable plantations lands in distant locations.

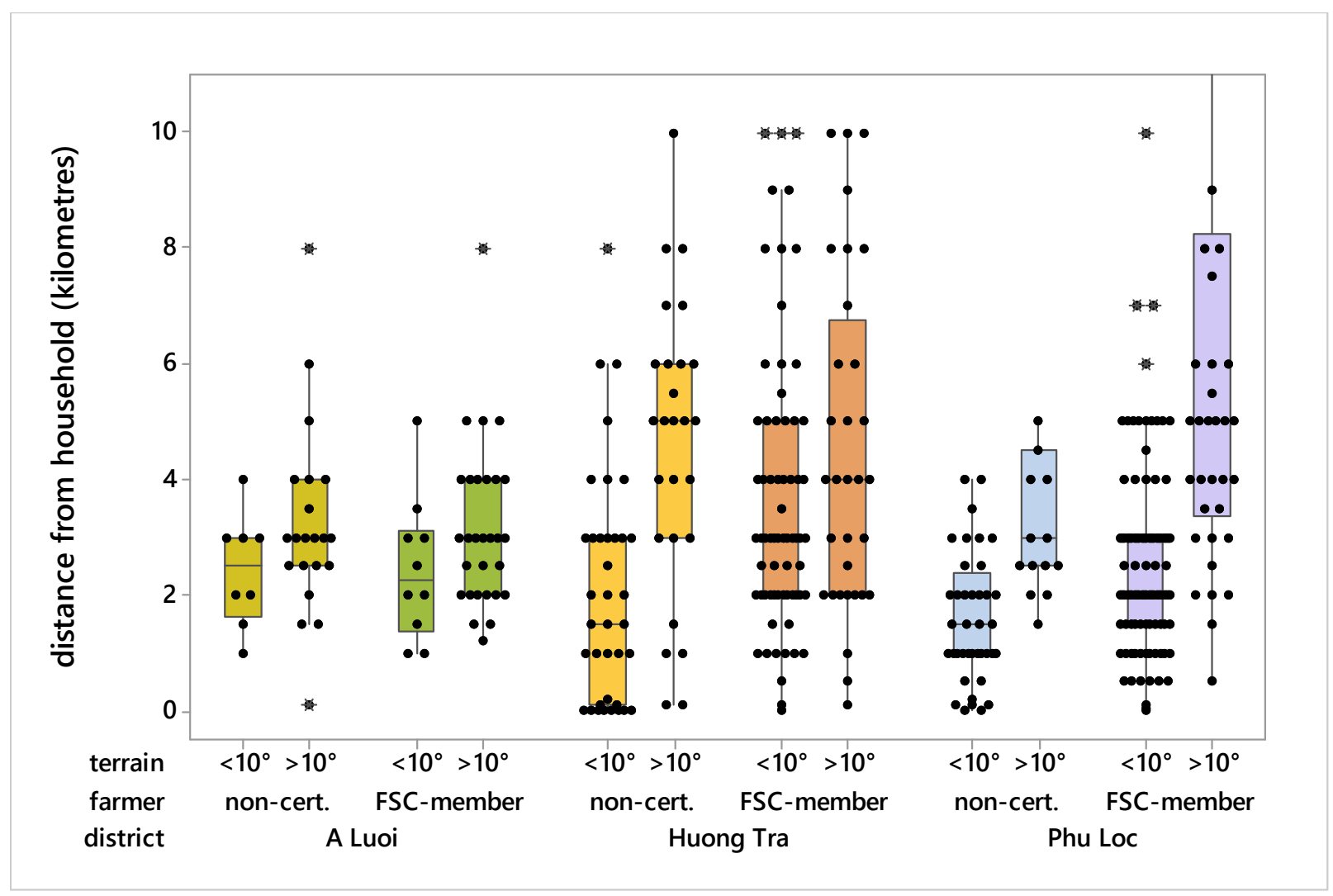

Figure 5. The distance of acacia plots from the respondents' homesteads, by district, tree farmer type (FSC-member or farmer with only non-certified plots), and plot terrain (plot slope more or less than $\sim 10$ degrees inclination). Boxplots cf. Figure 2. Eleven outlier points in Phú Lộc are not shown (beyond scale at distance $>11$ km, maximally 30 km; i.e., plots owned by three Nc- and eight FSC-farmers). All data from farmer interviews.

Figure 6 shows the size of acacia plots in relation to their spatial distribution, comparing different types of plot uses and ownerships (423 plots managed by the 180 respondents). FSC-farmers tended to have larger plots than Nc-farmers-if considering Nc-plots only. Furthermore, plot sizes tended to increase with increasing distance from the homesteadshowever, again, if considering Nc-plots only. Nc-woodchip plots co-owned by FSC-farmers included some of the largest and remotest plots (all plots located at $>5 \mathrm{~km}$ distance; steep 'plot distance-size' trend line in Figure 6). Similar to co-owned plots, Nc-sawlog plots owned by FSC-farmers tended to be relatively large, particularly in distant locations. This contrasted, however, with FSC-certified sawlog plots, which were more of average size (comparable to Nc-sawlog plots owned by Nc-farmers; Figure 6) and mostly located within relative vicinity of the FSC-farmers' homesteads ( $85 \%$ of plots located at $<4 \mathrm{~km}$ distance). There was no increasing trend of FSC-sawlog plot sizes with distance from homesteads (Figure 6). In summary, this indicates that in 2018 many FSC-farmers still largely relied on profits from Nc-woodchips and Nc-sawlogs produced on plantation estates in diverse 
locations. Plots for FSC-sawlog production still tended to be of well-proportioned, limited sizes and were often located relatively close to homesteads from where these plots could be easily accessed and managed - presumably also facilitating visits and controls for FSC audits.

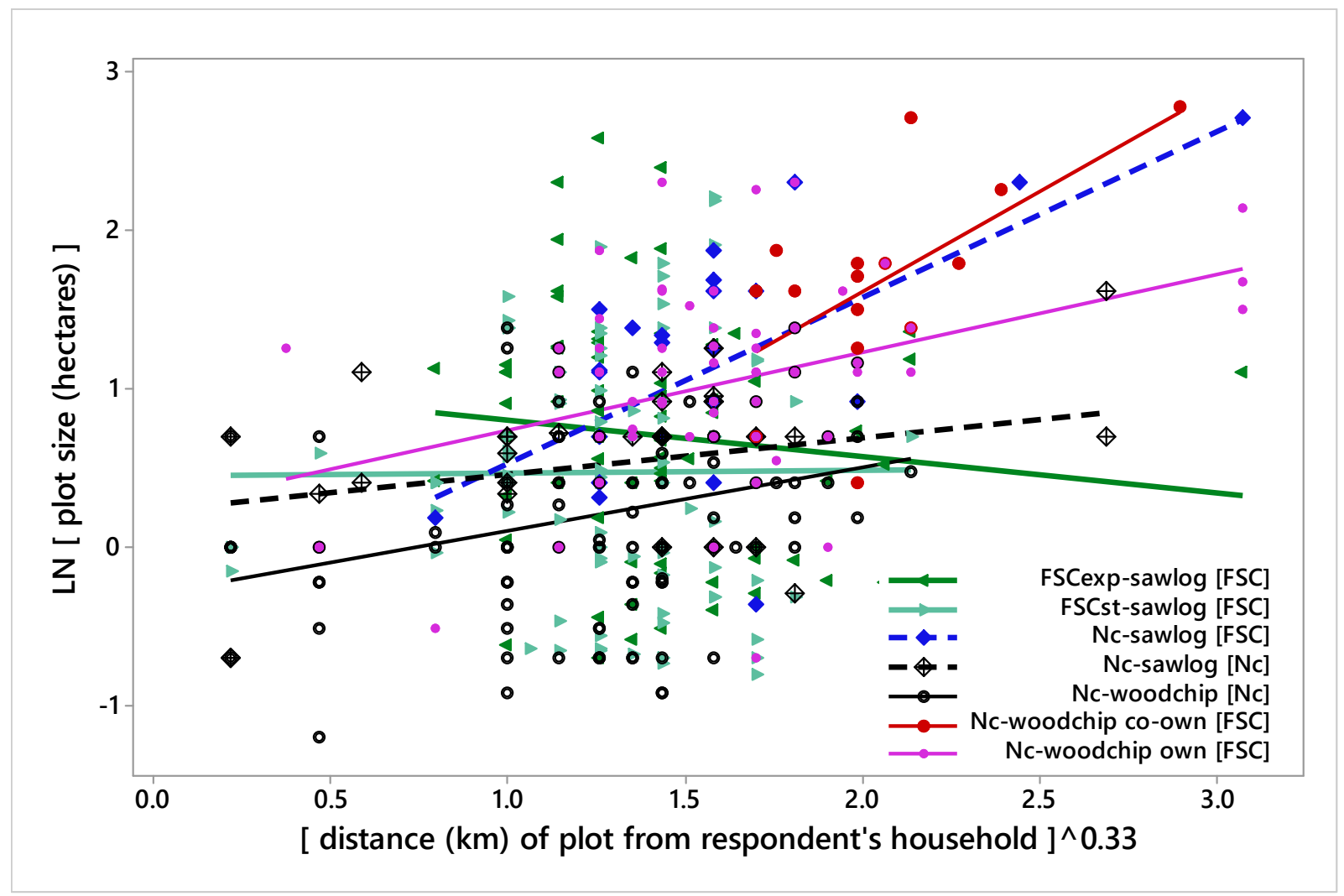

Figure 6. The size of acacia plantation plots (logarithmic scale) by plot type set in relation to the distance of the plots (0.33-power transformed scale) from the respondents' households. The plot types include (1.) plots used for FSC-sawlog production (differentiating among plots where FSC-sawlogs had already been exploited [FSCexp], and plots where FSCsawlog production had just started [FSCst]), (2.) plots used for Nc-sawlog production (owned by either FSC- or Nc-farmers), and (3.) plots used for woodchip production (owned by Nc-farmers, or owned or co-owned by FSC-farmers). Lines indicate a linear regression fit. All data from farmer interviews.

FSC-farmers in Phú Lộc had not only been 'pioneers' of acacia planting during the 1990s, but they were also among the first to join the FSC program. Many FSC-farmers in Phú Lộc (65\%) had already joined FSC in 2016, whereas most FSC-farmers in Hương Trà (74\%) and A Lưới (100\%) joined the FSC program later in 2017 or 2018. When asked about why they had joined FSC, 38\% of the FSC members in Phú Lộc (mostly of younger age) said that they had learned about FSC by joining information meetings, and many in Phú Lộc $(78 \%)$ and Hương Trà $(42 \%)$ noted that they saw economic benefits in participating in FSC. In contrast, all FSC members in A Lưới (100\%), many in Hương Trà $(61 \%)$, and some in Phú Lộc (24\%) answered that they were called upon to participate in FSC, or that they participated to serve as a 'leading example' and thus help develop sawlog production under FSC labels. These respondents were less likely to note having received much support from FSC or other programs for product certification or selling/marketing of the products. Two respondents (6\%) in Hương Trà noted that they received certain types of other support.

\subsection{Additional Land Assets Stocked with Non-Acacia Crops, Owned and Managed by the Acacia Tree Farmers}

In addition to acacia plots, some respondents in Hương Trà (28\%) and Phú Lộc $(8 \%)$ indicated that they also owned and managed rubber tree plantations $(2.3 \pm 1.4$ hectares on 
average); this included all respondents who had worked on rubber plantations in Hương Trà before planting acacias. Other respondents owned cultivations of pepper and areca palms (Piper nigrum and Areca catechu; 0.1-0.2 hectares; three respondents in Phú Lộc), fruit trees ( 1 ha; one respondent in Hương Trà), bananas ( 0.1 ha; one respondent in Hương Trà), or coffee ( 0.2 ha; one respondent in A Lưới).

Rice was the most common staple crop, which was still planted by $60 \%$ of respondents (especially the older ones) in A Lưới, 36\% in Hương Trà, and 21\% in Phú Lộc ( $2.3 \pm 1.4$ hectares on average). Cassava was planted by $38 \%$ of the respondents in A Lưới (of which $87 \%$ also planted rice) and $2 \%$ in Phú Lộc ( $0.3 \pm 0.2$ hectares on average). Other field crops mentioned by one different respondent each in Hương Trà included corn (0.1 ha), soybean (0.1 ha), lotus flower (1 ha), and grapefruit (0.1 ha).

\subsection{Configurations of Tree Farmers' Acacia Plantation Stocks and Rotation Cycles}

In 2018 the plantations of most respondents in Phú Lộc (89\%) and Hương Trà (94\%) were all stocked with acacia hybrids (Acacia mangium $\times$ auriculiformis), whereas tree farmers' plots in A Lưới were mostly stocked with original Acacia mangium (62\% exclusively mangium, $18 \%$ with plots of both mangium and hybrids; Table 5). One major reason may be that in remote A Lưới seedlings from cuttings of sterile acacia hybrids were less readily available (and costly for poor farmers) and/or implied higher dependencies from nurseries (often located outside of the communes), whereas mangium seeds could be freely collected and propagated $[124,125]$. Mangium trees were widely planted during pioneer phases of plantation development; for this reason, a significant ratio of sawlog producers mentioned that they still had plots stocked with (older-growth) mangium trees (30\% vs. $14 \%$ of Nc-woodchip farmers; Table 5). Similarly, respondents who had participated in the early 'reforestation' Program 661 were not unlikely to have some plots still stocked with mangium. In contrast, most respondents (95\%) who had received seedlings through support programs planted hybrid acacias only. Compared to mangium, hybrid acacias are probably better adapted to variable environmental conditions (modified nutrient-poor soils, variable temperature, and soil moisture regimes) and are therefore now preferred, especially by farmers in the lowlands, where seedlings from cuttings are readily available from nurseries at acceptable prices [46,124-127]. In fact, many respondents in Phú Lộc $(43 \%)$ and Hương Trà (36\%; Table 5) — mostly 'early planters' with large plantation areas and those who took up a loan-explicitly mentioned that they had changed tree propagation from raising seedlings from seeds (i.e., mangium) to raising seedlings from cuttings (i.e., most likely sterile hybrids). All farmers (including those with mangium) stated that seedlings used for plot replanting are nowadays propagated using tree cutting techniques, either at state-owned nurseries or small nurseries in the village neighborhood.

The average tree harvest rotation time for plots assigned for woodchip production was longer in upland A Lưới (5.1 \pm 0.2 years, range 4.5-6) as compared to Phú Lộc and Hương Trà ( $4.3 \pm 0.5$ years, range $3.5-6$; Table 5$)$. This may be due to slower tree growth rates within a slightly cooler upland climate [127] or differences in soil fertility ${ }^{9}$. Alternatively, differences in farmers' economic potentials and plantation management (e.g., fertilizer uses) may also explain tree growth differences and/or farmers' wood harvesting decisions (cf. later sections). The average rotation times tended to be longer if the respondents owned more than one plot assigned to woodchip production. Controlling for this factor, there was no significant difference between farmer types, but women respondents tended to indicate slightly faster rotation times for their woodchip plots than men. These results indicated that land ownership and household income status influenced farmers' decisions with regard to tree harvesting time.

Rotation times for plots assigned for sawlog production were on average around 1.6 times higher than for woodchip plots, i.e., $7.6 \pm 0.6$ years (range 6-8) in A Lưới and $6.7 \pm 0.7$ years (range 5-8) in Phú Lộc and Hương Trà. Sawlog rotation times were around 1.2 times longer for FSC-certified plots as compared to non-certified plots (Table 5). 


\subsection{Complementary Products and Income Opportunities from Acacia Plantations}

Several farmers (31\%) stated that they earned a side income from non-wood products derived from their plantations. Half of the respondents in A Lưới ( $50 \% ; 55 \%$ of those maintaining permanent cassava fields) and 13\% in Phú Lộc still used some of their acacia plots for planting cassava as an intercrop (often intermixed with newly planted acacia seedlings) during the first year after tree harvesting (Table 5). This corresponds to cultivation patterns also described from other upland regions in TTHP where ethnic minority people had switched from swiddens to new tree plantation regimes [36,122]. Several respondents in Phú Lộc (16\%) and Hương Trà (20\%; Table 5)—mostly smallholders who had participated in programs by WWF-mentioned that they had previously planted cassava intercrops but have since given up this agricultural practice. Some farmers $(12 \%)$ earned a side income from selling firewood collected on their acacia plots during tree pruning and plot weeding. Most of the 'firewood collectors' were Nc-woodchip farmers (with lower education) in the lowlands who had started planting acacias in relatively recent times (Table 5). In addition, six farmers in Phú Lộc and one in Hương Trà said they produced honey from bee keeping in plantations.

Acacia plantations in the surrounding neighborhood also provided opportunities for collaborations, additional incomes, and specialized businesses. Almost all Nc-woodchip $(97 \%)$ and Nc-sawlog $(82 \%)$ farmers, as well as a few FSC-farmers $(27 \%)^{10}$, said they earned wages or occasional 'collaborative incomes' from working or helping out on other farmers' acacia plots (Table 5). Similarly, many Nc-woodchip (87\%) and Nc-sawlog (61\%) farmers and some FSC-sawlog producers (36\%) said they were hired for specific work by other plantation owners (from planting to harvesting). Conversely, $77 \%$ of Nc-woodchip producers and $89 \%$ of sawlog producers (mostly sufficiently well-to-do respondents with many acacia plots) stated to at least sometimes hire other farmers to work on their plots (Table 5). Five FSC-farmers in Phú Lộc and four in Hương Trà said that they also worked as 'middlemen' to help other farmers sell their acacia wood products. Furthermore, one farmer in Phú Lộc and one in Hương Trà noted that they work as sawyers.

\subsection{Configurations of Acacia Plantation Management: Stand Thinning and Tree Pruning}

Comparative and experimental studies [99,128-131] have shown that tree stand thinning increases the wood volume and qualities/values of sawlogs produced in fast-growing acacia plantations. The thinned-out trees can thereby be sold for pulp production. Stand economic productivity may also benefit—at least to a certain degree-from tree branch pruning. Pruning usually increases wood biomass volume in acacia stands aimed at both woodchip and/or saw-log production, improves sawlog properties for furniture production, and can provide additional benefits such as firewood and/or biomass residue inputs for soil protection and enrichment $[36,99,120,132]$. Pruning practices can, however, also increase the risks of plant diseases in Vietnamese acacia plantations, notably an infestation of wilt disease caused by the saprophytic fungus Ceratocystis manginecans [133].

In our study, tree stand thinning in plantations was only applied by FSC-sawlog producers, mostly by generally well-off and better-educated plantation owners in the lowlands (especially Phú Lộc; Table 5). Most of the FSC exploit respondents stated that they had already been thinning out some of their plantations (89\%) or would do so in the near future $(7 \%)$. In contrast, only one FSC «start respondent had already applied thinning, but $59 \%$ stated that they would apply thinning within less than seven years (on average after $2.8 \pm 1.7$ years time). Thinning was done once per rotation cycle; only one respondent noted to conduct two rounds of thinning. All the respondents who had already applied thinning noted that it was needed in order to open space to grow quality sawlogs; most $(92 \%)$, however, also remarked that thinning was profitable because money earned from the harvested wood outweighed the associated labor costs. Stand thinning was not conducted in cases where labor and transportation costs were considered to be exceedingly high (e.g., owing to difficult site access). 
In contrast to thinning, a majority of farmers (89\%) applied tree branch pruning techniques to their acacia plantations, with $39 \%$ conducting pruning once and $50 \%$ twice per stand rotation. Those not applying pruning were mostly upland farmers (Table 5) with relatively smaller plantation plots managed for short stand rotation cycles, often located in steep terrain. In contrast, stand pruning was done more than once, mostly by well-educated and/or well-trained farmers who owned more than one acacia plot, often located in relatively even terrain. When asked about the reason for applying pruning, most $(93 \%)$ stated that it was done in order to foster tree growth or to develop the tree trunk. Many (69\%, predominantly FSC-sawlog producers) also referred to the thinning of trunks of multi-stemmed trees as a type of pruning. Many respondents had apparently practiced pruning since the beginning; only $8 \%$ explicitly noted they had started to apply tree branch pruning techniques in more recent times.

\subsection{Configurations of Acacia Plantation Management: Plot Weeding}

Naturally growing vegetation within the plantations may significantly compete with trees for water and soil nutrients, and-during the first 1-2 years after acacia planting-for light. In addition, dry undergrowth biomass may increase the risks of fires penetrating plantations [44,125]. Plant-soil interactions within plantations under different management regimes are, however, still little studied and poorly understood [132]. By removing soil cover, intensive weeding may result in negative effects on soil resources (in particular organic matter), and if weeding is conducted through ploughing, the fine roots of acacia trees are affected, and ruderal weeds may be promoted [134]. Underneath closed plantation canopies, competitive pressure from undergrowth plants appears to pose lesser risks, and may perhaps even offer some benefits through increased bioactivity, nutrient cycling, and carbon accumulation $[132,135,136]$.

In our study, most of the farmers $(88 \%)$ stated that they cleared their acacia plantations from weeds, with $17 \%$ applying weeding once, $61 \%$ twice, and $11 \%$ three times per stand rotation. Weeding was more often done in the mid/lowlands (Table 5), and farmers conducting several rounds of weeding were likely to own several plantation plots; also, these farmers had likely participated in training programs. Most respondents had probably practiced weeding since the beginning (especially 'early planters' who had previously planted eucalypts); only 35\% of the 'weeders' (50\% in Phú Lộc; Table 5) explicitly noted that they had initially not been weeding their plots but had started weeding in more recent times.

\subsection{Who Buys, Harvests, and Transports the Acacia Wood Products?}

Farmers' decisions of tree harvesting partly depend on wood industry demands and contractual agreements with buyers [15,26,101,137]. In our study a majority of the FSC «exploit respondents (89\%) as well as a few other sawlog producers (14\% of Ncsawlog and $22 \%$ of FSC «start〉 respondents) ${ }^{11}$ sold their wood products directly to the paper mills and sawmills (major paper mills are located in Phú Lộc and adjacent lowland districts [26,52]). All the other respondents (i.e., 64\% of sawlog producers and $100 \%$ of Nc-woodchip producers; Table 6) sold their wood products to a middleman.

Most of the sawlog producers selling directly to a mill (76\%) hired a team to harvest their plantations; the others (24\%; mostly younger and lesser-educated owners of comparatively recently planted large plantations) stated that they themselves harvested their plantations. Almost all plantation owners who sold their wood products to intermediaries (99\%) let the product buyers organize the plantation harvesting; only two respondents $(1 \%)$ noted that they themselves organized a team to harvest their fields, whereas the products were transported by the buyers. The transport of the products to the mill was in most cases done by the same actors (owners, hired teams, teams organized by intermediaries) who had harvested the plots. 
Table 6. Summary of data on acacia tree harvesting and replanting times, post-harvest plot management practices, and product selling, showing differences among the three study districts and farmer types.

\begin{tabular}{|c|c|c|c|c|c|c|c|c|}
\hline \multirow{2}{*}{$\begin{array}{c}\text { All } \downarrow \\
\text { District } \downarrow \downarrow \\
\text { Farmer Type } \downarrow \downarrow \downarrow\end{array}$} & \multicolumn{2}{|c|}{ Tree Harvest Season } & \multicolumn{4}{|c|}{ Post-Harvest Burning of Plant Residues on Plots } & \multirow{2}{*}{$\begin{array}{l}\text { "Preserve } \\
\text { Vegetation } \\
\text { on Plots" }\end{array}$} & \multirow{2}{*}{$\begin{array}{l}\text { Planting } \\
\text { Time Dep. } \\
\text { Seedlings }\end{array}$} \\
\hline & $\begin{array}{c}\text { Dry } \\
\text { Season }\end{array}$ & $\begin{array}{l}\text { Season } \\
\text { Depends }\end{array}$ & $\begin{array}{l}\text { "No Residue } \\
\text { Burning" }\end{array}$ & $\begin{array}{c}\text { Plot } \\
\text { Burning }\end{array}$ & $\begin{array}{l}\text { Plot Areas } \\
\text { Burnt } \% 1\end{array}$ & $\begin{array}{l}\text { "Burning > } \\
\text { No Burning" }\end{array}$ & & \\
\hline Overall & $59 \%$ & $39 \%$ & $49 \%$ & $51 \%$ & $85 \pm 26$ & $24 \%$ & $31 \%$ & $14 \%$ \\
\hline in Phú Lộc & $60 \%$ & $34 \%$ & $66 \%$ & $33 \%$ & $74 \pm 25$ & $31 \%$ & $40 \%$ & $0 \%$ \\
\hline in Hương Trà & $76 \%$ & $24 \%$ & $49 \%$ & $50 \%$ & $87 \pm 27$ & $24 \%$ & $30 \%$ & $4 \%$ \\
\hline in A Lưới & $28 \%$ & $72 \%$ & $23 \%$ & $68 \%$ & $92 \pm 23$ & $10 \%$ & $15 \%$ & $55 \%$ \\
\hline Nc-woodchip & $34 \%$ & $65 \%$ & $16 \%$ & $74 \%$ & $99 \pm 7$ & $3 \%$ & $3 \%$ & $24 \%$ \\
\hline Nc-sawlog & $75 \%$ & $21 \%$ & $43 \%$ & $71 \%$ & $81 \pm 24$ & $7 \%$ & $11 \%$ & $4 \%$ \\
\hline FSC-sawlog & $71 \%$ & $27 \%$ & $74 \%$ & $29 \%$ & $62 \pm 32$ & $43 \%$ & $56 \%$ & $10 \%$ \\
\hline All $\downarrow$ & \multirow{2}{*}{\multicolumn{3}{|c|}{$\begin{array}{l}\text { Time Delay (days) from Stand Harvesting } \\
\text { to Plot Replanting }{ }^{2}\end{array}$}} & \multirow{2}{*}{\multicolumn{3}{|c|}{$\begin{array}{l}\text { Fertilizer Applications on Plots } \\
\text { per Stand Rotation Cycle }\end{array}$}} & \multicolumn{2}{|c|}{ Wood Product Buyer } \\
\hline \multirow{2}{*}{$\begin{array}{c}\text { District } \downarrow \downarrow \\
\text { Farmer Type } \downarrow \downarrow \downarrow\end{array}$} & & & & & & & \multirow{2}{*}{$\begin{array}{l}\text { Sell to Mid- } \\
\text { dlemen }\end{array}$} & \multirow{2}{*}{$\begin{array}{l}\text { Sell to } \\
\text { Sawmill }\end{array}$} \\
\hline & $\sim<30 \mathrm{~d}$ & $30-60 \mathrm{~d}$ & $\sim>60 \mathrm{~d}$ & None & One Time & Twice $^{3}$ & & \\
\hline Overall & $41 \%$ & $32 \%$ & $27 \%$ & $21 \%$ & $39 \%$ & $40 \%$ & $78 \%$ & $23 \%$ \\
\hline in Phú Lộc & $61 \%$ & $32 \%$ & $7 \%$ & $9 \%$ & $34 \%$ & $57 \%$ & $71 \%$ & $32 \%$ \\
\hline in Hương Trà & $31 \%$ & $40 \%$ & $29 \%$ & $7 \%$ & $49 \%$ & $44 \%$ & $76 \%$ & $24 \%$ \\
\hline in A Lưới & $0 \%$ & $6 \%$ & $94 \%$ & $65 \%$ & $33 \%$ & $2 \%$ & $95 \%$ & $5 \%$ \\
\hline Nc-woodchip & $11 \%$ & $51 \%$ & $38 \%$ & $37 \%$ & $45 \%$ & $18 \%$ & $100 \%$ & $0 \%$ \\
\hline Nc-sawlog & $30 \%$ & $37 \%$ & $33 \%$ & $7 \%$ & $43 \%$ & $50 \%$ & $89 \%$ & $14 \%$ \\
\hline FSC-sawlog & $63 \%$ & $20 \%$ & $17 \%$ & $13 \%$ & $34 \%$ & $52 \%$ & $60 \%$ & $42 \%$ \\
\hline
\end{tabular}

${ }^{1}$ Calculation excludes data of farmers who did not practice post-harvest burning. ${ }^{2}$ Calculation excludes data of farmers who noted that the 'planting time depends on seedling availability'. ${ }^{3}$ Five respondents indicated frequency as 1.5 (one/two depending on plot type); these were counted as two applications.

\subsection{Configurations of Plantation Management: Harvesting Time, Soil Protection, Replanting, Fertilizer Uses}

Whether or not land conversion to acacia plantations improved specific soil qualities and overall 'soil fertility' perspicuously depended on site-specific soil characteristics as well as plantation management. Establishment of acacia plantations has recurrently been shown to improve (to some degrees) soil structure, carbon content, plant nutrient conditions (in particular nitrogen content), and microbial bio-activity on highly impacted sites, i.e., sparsely vegetated bushlands and bare lands, or overused crop fields [45,99,138-141]. In contrast, conversion of secondary natural forest or densely growing 'bushlands' (including old swidden fallows [142]) into plantations may have led to some types of soil degradation. For example, several studies ([112,138,143,144]; but see [113] for a differing assessment) reported that soils of acacia plantations became more acidic (in parallel with decreases in exchangeable cations) as compared to soils under natural vegetation, with potentially progressively decreasing soil fertility. Yet, rainwater-induced soil erosion processes probably pose considerably more serious problems for plantation management in Vietnam [44].

It should be noted that, despite a pervasive political-discursive 'naturalization'12 of acacias as 'forest', most anthropogenic monocultures of acacias in Vietnam are evidently not 'forests' in terms of representing permanent high-biomass woody ecosystems. Rather, acacia plantations are simplified, dynamically transforming vegetation systems where forest-like tree stands are at once (after plot harvesting) replaced by bare soil. This bare land is successively overgrown by grasses, herbs and/or planted inter-crops (e.g., cassava) with (after acacia replanting) woody components; it then grows into a form of bushland; and eventually (after 3-4 years) returns to an intermittent uniform forest-like state. Within one plot-systemic tree harvest rotation cycle, different successive vegetation states may exert differing influences on soil chemistry and biota. Relevantly, the non-tree plantation states (especially bare soil) are most vulnerable to soil erosion, especially in steep terrain [145-151]. Such risks are highest during the wet season (in TTHP from late September to December [152]) when strong monsoon rainfalls and occasional typhoons are frequent. Correspondingly, the timing of tree harvesting, post-harvest plot 
management (plant residue management, use of fire, soil compaction with trucks and machinery), inter-rotation period, and the timing and practices of plot replanting (planting technique, fertilizer uses) all exert non-negligible influences on the magnitude of soil erosion risks [95,129,132,153-155].

In our study, most of the sawlog producers (72\%) and a third of the woodchip producers (34\%) always harvested the trees during the dry season (Table 6). As a reason, $96 \%$ of these 'dry season harvesters' mentioned that transport of the acacia logs was easiest during the dry season; only a few respondents noted 'good wood prices' (2\%) or other economic reasons (2\%). Four respondents at Phú Lộc (where wood processing facilities are easy to reach on well-developed roads) stated that they usually harvested the trees during the wet season. These 'wet season harvesters' noted that the wood was heavier after long rain spells (i.e., containing more water); the wood therefore presumably yielded higher per hectare revenues. All other respondents (i.e., 25\% sawlog and 65\% woodchip producers, and mostly in A Lưới; Table 6) stated that they harvested the trees at any season, depending on specific conditions. Economic conditions were noted by most of these respondents (81\%) to influence the harvest timing, whereas others (19\%) noted conditions of accessibility and/or availability of transport means. Many of these 'variable/opportune season harvesters' had started acacia farming in relatively recent times, and many had received program support for selling wood products. They were also not unlikely to plant cassava as intercrops on harvested acacia plots, and they were less communicative about soil conservation measures.

A majority of the respondents (54\%) stated that they applied certain measures to protect their plots from soil erosion. Most of these respondents (i.e., $89 \%$; 49\% in total) noted that, as a post-harvest soil protection measure, they did not burn any vegetation residues covering the ground. Respondents referring to this 'no burn' measure were mostly relatively well-off farmers in the mid/lowlands with comparatively large plantations that were commonly stocked with long-rotation stands aimed for sawlog production (Table 6). These farmers were also likely to have received fertilizers through support programs; hence, ash from burnt vegetation was not needed to boost plant nutrients during plot replanting [156].

A similar image was provided from farmers' information about the percentage plantation area that was effectively burnt after harvests. Mostly Nc-woodchip (74\%) and Nc-sawlog (71\%) farmers, predominantly in A Lưới and Hương Trà, noted they were burning at least some of their plots (Table 6). Since FSC certification standards disallow post-harvest burning [80], the rate was significantly lower for FSC-sawlog producers. Nonetheless $29 \%$ of FSC-farmers (with two exceptions all FSC «start〉 respondents) noted that they still burn some of their non-certified plots (on average $62 \% \pm 32 \%$ of their plantation areas; Table 6). The burning of vegetation residues was more commonly done by older respondents, 'latecomers' in acacia planting, and/or generally the poorer and more marginalized farmers with entitlements to relatively inferior land assets ${ }^{13}$. Only a small number of Nc-woodchip (3\%) and Nc-sawlog (7\%) farmers explicitly noted that they had changed from post-harvest plot burning to a no-burning regime, whereas this statement was quite frequent for FSC-farmers (43\%; Table 6).

Among the $54 \%$ respondents who asserted that they apply soil protection measures, $57 \%$ (31\% in total) also noted that they safeguard some natural vegetation within (e.g., ground covering grasses, small shrubs) and/or around the edges (bushes, trees) of their plantations (Table 6). These respondents were predominantly FSC-sawlog producers (often with a leadership position) or otherwise better-placed owners of mostly long-rotation acacia plots and connections to international $\mathrm{NGOs}^{14}$, including those who owned acacia plots in far-away locations, i.e., plots that are already difficult to access and costly to treat for weeding. In addition, some respondents applying erosion controls (11\%; $6 \%$ in total) in Phú Lộc and Hương Trà also noted that they employ specific techniques when replanting the plots with seedlings, such as specific planting arrangements ('Y-shaped' planting noted by $8 \%$ ) or forming 'ladder-like' mini-terraces on slopes (3\%). Only one respondent (1\%) 
specifically noted 'planting time' as an 'erosion-mitigating factor', stating that he harvested early in the dry season and planted the seedlings soon after harvests in order to re-establish a protective vegetation cover.

When asked about the time it takes in between plot harvesting and replanting, more than half of the respondents in A Lưới (55\%) and a few in Hương Trà (4\%) said that this mainly depended on the money available to buy acacia seedlings (Table 6). These were mostly relatively poor respondents, many of whom earned a side income through wage earning, and many of whom could apparently not afford to buy fertilizers (or did not want to spend money on fertilizers). Almost all the other respondents at A Lưới (94\%) indicated that they usually replanted their plots more than two months after tree harvests. In contrast, most respondents at Phú Lộc (93\%) and Hương Trà $(71 \%)$ stated that they usually replanted their plots within less than two months (Table 6). There were also significant differences among farmer types. Most of the FSC-sawlog producers (63\%) replanted their plots within only one month, whereas only a few Nc-woodchip producers $(11 \%)$ were as fast in replanting (Table 6). In addition to these differences among regions and farmer types, respondents tended to be faster at replanting their plots if they were well endowed with plantation assets, apparently valued their lands for traditional reasons, and/orcorrespondingly - if they took active soil protection measures (as explicitly stated) ${ }^{15}$.

Low levels of soil phosphorus $(\mathrm{P})$ exert significant limitations on plant growth in the rainforests of TTHP [157]. Accordingly, P is an important plant nutrient influencing woody growth on (historically rainforest-covered) soils in acacia plantations, especially during early growth after replanting $[155,158,159]$. In Vietnam, acacia farmers using fertilizers typically apply 100-200 g of an NPK fertilizer per tree mix at planting, whereby the effects of nitrogen $(\mathrm{N})$ and potassium $(\mathrm{K})$ are poorly understood. Notably, acacias fix $\mathrm{N}$ via their own roots, and the addition of $\mathrm{K}$ has not yet shown added growth responses in acacia plantations [44,45,154]. In Phú Lộc and Hương Trà, more than 90\% of the respondents applied NPK soil fertilizers ${ }^{16}$ at least once (usually during planting) and often twice (a second time after around 1-1.5 years) per stand rotation. In contrast, in A Lưới, only a minority of respondents (35\%) bought and applied these fertilizers (Table 6). Fertilizers were more often used by sawlog producers and better educated farmers, and especially farmers who weeded their plots frequently but did not burn plant residues after tree harvesting. Fertilizers also tended to be applied more often on relatively steeper plots.

In summary, the study results suggest that plot harvest and replanting times, fireuse practices, and fertilizer applications were largely determined by farmers' economic rationality and associated environmental and socio-political constraints. More concrete considerations and investments with relevance to soil protection were mostly at the leisure of well-established farmers with sizeable plantations in the lowlands. Education and training programs helped to form more explicit cognizance of specific environmental issues, but even well-off FSC-farmers did not always assign importance to soil conservation practices (e.g., 'no burn') if measures were not specifically required through FSC contracts. Weeding is labor-intensive, and fertilizers have to be bought at a price; this does not always lie within the budget and priorities of poor farmers. In contrast, the burning of harvest residue biomass is apparently considered by many farmers as an inexpensive and - under prevailing conditions and context-appropriate way to prepare the plots for replanting. Residue burning clears the plots of weeds, and many farmers apply controlled fires specifically to avert the risk of uncontrolled fires penetrating the plots after replanting [44,125]. Biomass burning returns plant nutrients to the soils, which can promote the growth and establishment of acacia seedlings (and in some cases, cassava or other intercrops) [156]. Fire may also serve to scarify seeds, thus helping to promote spontaneous recruitment of acacia seedlings after rains [160]. Within a longer time period, however, plot burning usually leads to net losses of plant nutrients through volatilization and higher rain-induced erosion risks of unprotected soils [95,129,132,154,161]. At a plot-systemic level, then, postharvest burning can therefore probably be considered a less sustainable practice than the more labor-intensive 'no burn' approaches. Farmers' capacities to invest in labor and 
fertilizers (with other associated 'externality costs' [162]), and their potentials to eventually attain a good income from tree harvests, are, however, not detached from broader environmental and socio-economic contexts. Besides 'sustainability' issues surrounding societal distributional equity (e.g., land tenure and associated politics of forest resource management $[31,36,56,163-165])$, the question may be posed whether acacia plantations are indeed the 'best' type of land use in all locations. Is acacia the 'natural' choice of 'all' rural people (including the less well-to-do farmers) for sustainable development of their livelihoods, in adequate accordance with environmental potentials and safekeeping?

\subsection{Maintenance of Natural Vegetation and Planting of Native Tree Species}

The ascent of so-called 'planted forests' of acacias may be seen as an obvious success by proponents of the wood industry. It may also be seen as a clear success by advocates of a fast ( breakneck?) modernization approach to rural 'development'. For people concerned with the value and conservation of biological diversity and associated diverse forms of nature-based human livelihoods and cultures, this development is, however, of a somewhat double-edged nature. On the one hand, the increased sourcing of wood and timber from industrial plantations and agroforests may appreciably mitigate other types of industrial resource-extractive (and usually ruinous) impacts on natural forestlands $[82,83,166]^{17}$. On the other hand, the enlargement of alien single-species tree monocultures has often replaced other types of land cover which may have been-in one way or another-somewhat 'ecologically degraded' but still contained comparatively far higher species diversity with associated values and uses [1,43,61,115-117]. In the quintessential 'biological desert' ${ }^{18}$ created by acacia-based 'novel forests', any remnants of native vegetation, or implanted native tree species [77], may thus markedly improve overall habitat qualities for some types of generalist birds, mammals, or other fauna or flora [167-169]. Likewise, certain ecosystem services (e.g., flood-prone riverbank protection near river courses [146]) may be better maintained by remnant natural vegetation in comparison to new rotational plantation systems.

In our study a number of respondents ( $43 \%$ in total, Table 7) affirmed that they had kept or planted some native vegetation around their acacia plots. These 'native tree keepers' were mostly FSC-sawlog producers with plots of long rotation cycles (64\% of FSC «start and $100 \%$ of FSC (exploit respondents), and mostly those who said that they applied specific measures against soil erosion. The data analyses also suggest that respondents who had participated in Program 327 (a program which largely focused on planting acacias) were somewhat less likely to plant and/or maintain any natural vegetation.

Table 7. Summary of data on native vegetation planting and conservation in and around acacia plantations, showing differences among the three study districts and farmer types.

\begin{tabular}{|c|c|c|c|c|c|c|c|c|}
\hline \multirow{3}{*}{$\begin{array}{c}\text { All } \downarrow \\
\text { District } \downarrow \downarrow \\
\text { F. Type } \downarrow \downarrow \downarrow\end{array}$} & \multirow{3}{*}{$\begin{array}{l}\text { Acacia Plots } \\
\text { Close to } \\
\text { River/Creek }\end{array}$} & \multirow{3}{*}{$\begin{array}{c}\text { Keeping } \\
\text { Native Trees } \\
\text { Vegetation }\end{array}$} & \multirow{2}{*}{\multicolumn{2}{|c|}{$\begin{array}{l}\text { Native Timber Species } \\
\text { Planted on or near Plots }\end{array}$}} & \multirow{3}{*}{$\begin{array}{l}\text { Preserve } \\
\text { Natural } \\
\text { Woodlots }\end{array}$} & \multicolumn{3}{|c|}{ Reasons for Keeping Native Vegetation } \\
\hline & & & & & & \multirow{2}{*}{$\begin{array}{l}\text { "Erosion } \\
\text { Control" }\end{array}$} & \multirow{2}{*}{$\begin{array}{l}\text { “Delimit } \\
\text { Plots" }\end{array}$} & \multirow{2}{*}{$\begin{array}{c}\text { "Pest } \\
\text { Control" }\end{array}$} \\
\hline & & & Hopea & Homalium & & & & \\
\hline Overall & $42 \%$ & $43 \%$ & $29 \%$ & $11 \%$ & $22 \%$ & $28 \%$ & $17 \%$ & $12 \%$ \\
\hline in Phú Lộc & $43 \%$ & $50 \%$ & $40 \%$ & $20 \%$ & $24 \%$ & $34 \%$ & $26 \%$ & $14 \%$ \\
\hline in Hương Trà & $36 \%$ & $43 \%$ & $30 \%$ & $7 \%$ & $17 \%$ & $29 \%$ & $19 \%$ & $14 \%$ \\
\hline in A Lưới & $50 \%$ & $33 \%$ & $8 \%$ & $0 \%$ & $25 \%$ & $15 \%$ & $0 \%$ & $3 \%$ \\
\hline Nc-woodchip & $56 \%$ & $5 \%$ & $0 \%$ & $0 \%$ & $3 \%$ & $2 \%$ & $0 \%$ & $0 \%$ \\
\hline Nc-sawlog & $43 \%$ & $29 \%$ & $4 \%$ & $0 \%$ & $29 \%$ & $14 \%$ & $0 \%$ & $0 \%$ \\
\hline FSC-sawlog & $31 \%$ & $74 \%$ & $57 \%$ & $21 \%$ & $32 \%$ & $50 \%$ & $34 \%$ & $23 \%$ \\
\hline
\end{tabular}

Where creeks or rivers crossed the plantations, acacias were mostly planted in riparian zones by farmers ( $42 \%$ in total; Table 7 ) who harvested their plots at relatively short rotation cycles (e.g., woodchip or sawlog producers with relatively limited resources; this often included farmers who had taken up a loan, did not use fertilizers, and were not unlikely to plant cassava as intercrops). Among the 'native tree keepers', relatively fewer farmers 
(27\%) stated that they planted acacias adjacent to creeks and rivers. Furthermore, former participants in Program 661 (a program partly focusing on conserving natural vegetation) were somewhat less likely to plant acacias in riparian zones along watercourses.

Many 'native tree keepers' (67\%) were planting Hopea odorata trees. These respondents were commonly FSC-sawlog producers ( $87 \%$ of all FSC exploit and $44 \%$ of FSC «start respondents) in the mid/lowlands, many of whom owned plantation plots in fairly distant locations (Table 7). H. odorata is a dipterocarp rainforest tree native to parts of Southern Vietnam, where it is often found growing along river courses. In TTHP H. odorata does not, however, grow 'naturally' in forests; hence it is essentially another type of plantation tree that is mostly planted because of its high timber value [139]. Another valuable native timber species planted by several of those FSC-sawlog producers in the mid/lowlands was Homalium ceylanicum (37\% of FSC «exploit and 14\% of FSC sstart respondents; mostly planted by those who had received support from an NGO, including some who had bought additional plantation lands; Table 7). Furthermore, three respondents in Hương Trà and one in Phú Lộc planted trees of Chukrasia tabularis, and five in Hương Trà and three in Phú Lộc planted some species of native bamboo.

In A Lưới only three FSC producers (8\%) planted a high-value timber species (H. odorata), but several farmers in A Lưới (25\%) and in the mid/lowlands (21\%) kept naturally growing trees and bushes around their plots (Table 7). Indeed, among the 'native tree keepers', those who had preserved some naturally growing native vegetation were mostly well educated and apparently more environmentally aware farmers; many had stated to take soil protection measures, to harvest their plots in the dry season, and few of them set up plantations adjacent to creeks and rivers. Quite often, the respondents were FSC-farmers who, however, tended to have relatively fewer FSC-certified land areas and did not plant H. odorata trees.

When asked why they kept natural vegetation or planted native trees, $65 \%$ of the 'native tree keepers' (primarily FSC-sawlog producers) provided an answer, all except one noting control of soil erosion as a reason $(98 \% ; 28 \%$ overall; Table 7$)$. These were mostly older respondents, especially those who did not apply post-harvest burning of their plots. Some of these respondents (especially those who received specific training on certification by NGOs such as WWF) noted that they also used native vegetation to demarcate the boundaries of their plots $(61 \% ; 17 \%$ overall); in addition, some noted that the natural vegetation served to control pest species ( $43 \% ; 12 \%$ overall; Table 7$)$.

In summary, in line with previous findings, the results suggest that the maintenance of native vegetation components was mainly determined by farmers' practical economic rationales, within the confines of contexts and potentials. The term 'native vegetation' is somewhat flexible; many farmers (in correspondence with discourse by the wood industry [76]) seem to understand this mainly as referring to (native) timber species that provide added value and future opportunities with respect to a newly opening 'green market'. Cognizance of particular issues was probably partly activated through training programs, but the results of our survey also indicated some genuine considerations/efforts by several farmers to maintain remnant native vegetation in specific, potentially vulnerable locations, both within the lowland and upland districts.

\section{Concluding Notes and Corollaries}

Most of the plantations in TTHP still produce lower-quality wood grown on short rotations. Such woodchip-producing plantations are easier to manage, require fewer investments, and bear lesser risks (e.g., impacts by storms or plant diseases) than long-rotation sawlog-producing plantations [101]. For poorer farmers there is a relatively fast return of income, and since local and export demand for woodchips is high, the selling prices have been attractive and relatively stable [5]. Nonetheless, the largely plantation-based wood industry in Vietnam is in gradual transition, and rural socio-economic structural trends (demography, land tenure, political networks) are in dynamic interaction with significant trends in global market demands and associated pressures through progressive 
national strategic planning and policies. Within this context, wood certification schemes (such as by FSC) serve specific functions but hardly hold the ultimate answer to questions of 'sustainability'.

The word 'sustainability' may be associated with variable comprehensions and bearings ${ }^{19}$. In contrast, 'sustainable development', as an all-embracing policy concept ${ }^{20}$, essentially joins together two basic ideas/insights, namely (1.) that certain (human/societal) 'needs' exist, and that these needs need to be addressed (i.e., the 'development' aspect) ${ }^{21}$, and (2.) that fulfilment of such needs can - given environmental realities-be transient or perhaps even risky depending on how (by which pathways) the needs are addressed (i.e., the 'sustainability' aspect).

Some ecological characteristics of acacia trees, such as the species' capacity for fast tree growth on relatively non-productive soils, undoubtedly facilitated the establishment of 'planted forests'. Yet, other choices of 'forest' development would have existed. For example, during the 1990s, researchers demonstrated the possibilities of acacia plantations to enable the regeneration of natural rainforest (on sites of heavily degraded soils) through accelerated successional pathways [175-177]. In places, such as Hương Trà District, the establishment of acacia plantations, was, however, a more cogent pathway, as this allowed the creation of many jobs and significant income for a poverty-stricken growing rural population through the development of a wood-based and-nowadays-largely exportoriented industry. From a social-economic perspective at least, this pathway may-in basic principle - not have contravened 'sustainable development' as particularized through the SDGs [11]. Upon closer examination, however, and as shown to some extent through the results of our study, sustainability-relevant social-environmental issues remain conspicuous; this includes issues/concerns of equity, shifts in risk and resilience, clear spaces for farmers' own resourcefulness, and-correspondingly-social/cultural sensitivity and fairness in governance.

Even just within the low-/midlands (Phú Lộc, Hương Trà) where acacia-plantationfarming has become relatively settled, plantation land tenure was unequally distributed among different households. Rich landowners enjoyed good access to social-political 'capital', with a palette of options in land management, including presumably more sustainable forestry techniques. In contrast, relatively poor households (and disproportionately often households of ethnic minority people and women) mostly subsisted within foundational configurations of inequity - encodings which were largely reproduced via allocations of new development programs, and via formulations of new incentive schemes and policies [178]. This included the FSC program, which mostly follows a pattern that understands 'sustainable development' largely through a lens of economic-developmental primacy and marketing. With regard to a range of approaches towards more sustainable livelihoods (e.g., the diversification of products and land uses/management besides the production of acacia wood), the articulation of alternative pathways and poverty-focused incentive schemes remained marginal. Facilitation of spaces/motivation for local community-based innovations and initiatives (e.g., securing better livelihoods and more effective terrain-adapted soil protection measures) was barely within the scope of over-riding 'development'.

From a more environmental-ecological perspective on 'sustainability', the formation of an extensive uniform acacia-wooded land cover may be seen as a momentous and wide-ranging 'baseline shift' [179]. Acacia plantations are largely new 'terrain', inasmuch as any understanding of the actual long-term stability and overall social-ecological value of such 'novel forest ecosystems' is not based on much previous historically grounded experience, or-idem-accumulated wisdom based in 'tested' science. One may sensibly believe that a land cover of acacia plantations provides better long-term protection against soil erosion/degradation and against risks of catastrophic flooding than a land cover of secondary bushlands ( 'bare hills'), but—as a matter of fact—-there are no studies which have addressed such questions in Vietnam in a genuinely scientific and comprehensive way. What can be said with certainty is that 'acacia forests' are anthropogenic ecosystems which are almost void of native fauna and flora. Within such ecosystems there is barely 
any resilience in terms of natural 'checks and balances' and substitutive replacement by diverse species, such as in rainforests [180]. Scientists working on the 'sustainability' of acacia plantations are very much aware of this, as is evidenced by plant pest and pathogen guidebooks [98], which may serve for natural hazard impact preparation. Problems with acacia pests and pathogens (as already encountered by some respondents of our study) will not always remain at a near-negligible level. Any critical damage, such as has already occurred in other parts of Southeast Asia [96,97,181], can be expected to lead to new shifts and configurations. Adaptation in any such event may be partly facilitated through scientific research and technical innovation. Other lingering threats, such as those posed by climate change, may, however, modify and complexify the parameters of pathogen outbreaks in combination with other risks [182,183]. In case of momentous 'systemic collapse' (such as caused through a fast epidemic pest outbreak), a shift to other land use options may be the only reliable 'sustainability insurance'. For this and other reasons, the safeguarding of natural ( species and breeds) as well as cultural ( traditional agricultural knowledge) options is important (keyword: diversity). This noted, sustainabilities/changeabilities and associated current trajectories are evidently not disconnected from spatial and historic patterns and configurations.

In the low-/midlands of TTHP, much of the mildly undulating landscape is now covered by an almost unbroken, uniform carpet of acacia plantations. Some lowland rainforests only persist as slim degraded remnants in pockets of steep terrain or on riverbanks [61]. Keeping this in mind, the idea to improve the preservation of lowland rainforest resources perhaps via small conservation areas or via the restoration of 'greenbelt corridors' (e.g., natural tree groves along watercourses or hill ridges) is not wrong in principle. The idea, however, needs to find sufficient 'sustainable' resonance (and associated spaces and capacities) with local land managers. In this regard FSC certification alone does not appear as a satisfactory avenue. The entry costs to participate in FSC are high and currently exclude most plantation owners (cf. above). Reasons to participate in FSC are primarily of an economic-political nature, as FSC is exclusively directed towards the (economically profitable) production of (more) acacia timber. Within the FSC system, changeability in management towards more 'environmental sustainability' is probably more often a positive by-product in the form of compliance to industry standardized requirements, rather than arising from genuine engagement and local community-based innovation in environmental stewardship.

Ascending inland towards steeper terrain and upland mountain areas, the acacia plantation 'carpet' is more and more broken and replaced by a mosaic natural vegetation cover of rainforest and thickets. Rainforests that have escaped major impacts of war have served to supply state forest enterprises (SFEs) with timber during the post-war period (1975 until 1990), i.e., timber which will not regrow to a 'harvestable' size and quality for decades. Hence, for the wood industry the upland rainforests were the 'unsustainable' predecessors of wood-rotational acacia plantations [1]. Until today, most natural forestlands remained under the effective ownership and control of state forest organizations (SFCs, MBPFs) $[60,63,163,165]$. This also includes state-defined 'forestlands', which have previously served as rotational swidden areas for subsistence of upland ethnic minority people. Most abandoned swidden areas, alias 'forestlands', have not reverted to forest but persist as an alternate vegetation state, i.e., a carpet of dense vine-bamboo thickets. Other open thicket areas-often on steep slopes-may have formed as a consequence of war impacts. Some of these open areas have been planted with acacias (largely under Program 661 [49]) purportedly to be 'restored' as 'watershed protection forests' - i.e., 'planted forests' which successively became colonized by native tree species, which will likely eventually revert to some forms of rainforest $[176,184]$. Many of these old ( $>15$ years) acacia-based 'protection forests' have however recently ${ }^{22}$ been logged out ( harvested) for timber by SFCs and MBPFs [60], despite the antecedent green rhetoric [48] that was recurrently complemented by real issues of landslides and floods during storm events [185-187]. 
Such observations on land management by state forest organizations may be contrasted with the verity that (1.) the swiddening practices of local people have recurrently been blamed in mainstream political discourse for many environmental problems, including soil erosion and downstream catastrophic flooding, and that (2.) during historic times (and in other regions until today), subsistence agriculture was presumably relatively sustainably practiced within rotational swidden systems-insofar as these systems were (are) indeed still 'traditionally' managed [1,35,42,188-190]. Since the 1990s the uplands of TTHP have been in the state's focus for strategic infrastructure development, such as the construction of large hydro-electric dams and roads-developments with often substantial concomitant environmental impacts. The drive for modernization included the prohibition of swiddening and the resettlement of many ethnic minority communities. The resettled people often assessed those new living areas as being of relatively lower environmental quality, because (1.) land suitable for planting rice (which was allowed and promoted by government programs) was often very limited, and (2.) the prohibition of swiddening was rarely accompanied by adequate compensations [31,33,191]. As a consequence, in the post-swidden era, the needs of local people were initially often covered by the collection of forest wood products, including 'illegal' selective logging and the collection of war residue metal [37,192,193].

Within traditional upland agricultural systems in TTHP planting and aided regeneration of native tree species had been a common practice and form of knowledge, which has, however, subsided along with the imposed relinquishment of swiddening. In principle, there is a diverse array of relatively fast-growing useful native tree species (e.g., Macaranga, Mallotus, Ormosia, Cinnamomum, and Castanopsis spp.) that could perhaps still be planted for livelihoods and economic gain [42,194-198]. Currently, however, tree planting all seems to be about industrial acacia ${ }^{23}$, i.e., an alien tree 'species' whose 'career' started during the 1990s in the lowlands as a pre-eminent 'ecological option', and which has arrived in the uplands as a politically accepted 'marketable option' that allows the local people to regain an initiative in tree planting and 'forest' land use, on officially or otherwise available land.

Upland farmers in TTHP are not exempt from the risks of progressive climate change [202]. From their perspective, however, protracted issues of land tenure and access are probably of more immediate concern, and - within this hitherto shifting context-available options to better secure and develop their livelihoods. In the delicate environment and multi-layered historic context of the uplands, the 'setting' for 'sustainability' is naturally non-trivial. Comprehensive environmental governance directed at 'sustainable development' ("meeting the needs") requires mindful approaches towards issues of social-environmental sensitivities and fairness/justice. To cite Sikor et al. ([203], p. 525), "[ . . ] environmental behaviour of stakeholders is likely to depend on how they perceive the legitimacy and fairness of ecosystem governance". Available 'spaces' and opportunities (perhaps with appropriate incentives/subsidies) will allow farmers to engage on their own motivations in adequate developments for sustainable livelihoods, agricultural innovations, and genuine land stewardship.

Supplementary Materials: Supplementary data for this article are available online at: https:/ /www. mdpi.com/article/10.3390/land10121304/s1.

Author Contributions: R.C.: Conceptualization, Methodology, Data curation, Formal analysis, Visualization, Writing—original draft, Writing—-review and editing, Funding acquisition, Project administration. B.T.V.: Conceptualization, Methodology, Investigation, Data curation, Visualization, Writing — original draft, Writing—review and editing, Funding acquisition. D.T.N.: Conceptualization, Writing - review and editing. All authors have read and agreed to the published version of the manuscript.

Funding: This research (including APC funding) was made possible by grants (\#169430, \#194004) from the Swiss Programme for Research on Global Issues for Development (R4D Programme) cofunded by the Swiss National Science Foundation (SNF) and the Swiss Agency for Development and 
Cooperation (SDC). In addition, a grant for field support (USD 500) was provided to Vu Thanh Bien from the Asian Institute of Technology (AIT) in Bangkok.

Institutional Review Board Statement: Not applicable.

Informed Consent Statement: Informed consent was obtained from all subjects involved in the study.

Data Availability Statement: The data presented in this study are available on request from the corresponding author. The data are not publicly available due to reasons of privacy.

Acknowledgments: Special thanks are given to Le Nhan Tien from TTH-FOSDA for support in data collection. The authors thank the respondents of Thừa Thiên Huế Province who participated in this study.

Conflicts of Interest: The authors declare that they have no known competing financial interests or personal relationships that could have appeared to influence the work reported in this paper.

\section{Notes}

1 Plan No.204/KH-UBND dated 28/12/2016 of the provincial People's Committee, entitled 'Development of large timber/sawlog plantation in Thừa Thiên Huế Province for 2017-2020'.

2 Maps prepared around 1966 show the area of this commune mostly as forest and bushland.

3 Forestland is in essence lent by the state over a defined period, usually 50 years.

4 A Voluntary Partnership Agreement with the European Union, under the EU's FLEGT Initiative (European Union Forest Law Enforcement, Governance and Trade Action Plan), was signed in October 2018. Similarly, the Lacey Act (year 2008) in the US and the Illegal Logging Prohibition Act (2012) in Australia require the Vietnamese government to ensure that timber products exported to the US/Australia are not from illegal logging sources.

5 In some ethnographies the Pa Cô are described as a sub-group of the Tà Ôi [104].

6 This could be a position as commune leader, director of agricultural cooperative, cadastral registrar, chairman of commune farmers' association, and/or FSC team leader.

$7 \quad$ Prior to FLA eucalypt and rubber plantations were set up on state-owned or communal lands.

8 According to Nambiar et al. [96] eucalypt species (especially Eucalyptus camaldulensis) had initially been promoted by replantation programs in Southern Vietnam. Severe problems with leaf blight disease (Cylindrocladium quinqueseptatum [111]) in eucalypt plantations, however, caused a shift towards Acacia mangium which also showed very good growth results on degraded soils [112,113].

9 Some respondents noted that the soils of some plantation sites in Hương Lâm and Đông Sơn Communes were still affected by chemical residuals of Agent Orange from the war [40].

10 Mostly the younger and lesser educated and those who had not participated in plantation programs and associated trainings.

11 Data indicate that (in addition to factors of 'FSC') sawlog producers who sold products to a mill without intermediaries tended to be better educated and own relatively large tracts of plantation lands; they had often been supported by programs of NGOs (especially WWF), and/or had received support and training in FSC certification.

Acacia plantations feature in Vietnamese reports and statistics as 'planted forests' [60] and planting of acacias in Vietnam has routinely been described as 'reforestation', 'forest restoration', or 'forest rehabilitation' [1,12,49].

Data analyses indicate that (in addition to 'age' factors) the respondents tended to be farmers who had not been engaged in planting programs; had started planting acacias relatively recently; had not received support/training from NGOs; did not own permanent (separate from acacia plots) cassava crop fields (i.e., mostly in the uplands); and/or whose acacia plots were located in comparatively steep terrain.

14 Data analyses indicate that (in addition to factors 'FSC', 'honorary position', 'plot distance') the respondents were mostly farmers who had received fertilizers through support programs and/or who were thinning their plantations.

15 Data analyses indicate that (in addition to the other factors) many respondents owned plots with 'long-rotation acacia' and/or that many had depended on the plantation lands for gaining their livelihoods already before starting to plant acacias.

Standard NPK fertilizer was the only fertilizer mentioned, usually ( $90 \%$ of fertilizer users) with a mixed N:P:K concentration of 16:16:8 (at a price of $0.44 \mathrm{USD} \mathrm{kg}^{-1}$ ), but sometimes (10\%) of 10:10:5 $\left(0.31 \mathrm{USD} \mathrm{kg}^{-1}\right)$. Numbers are percentages, i.e., 16:16:8 represents $16 \%$ nitrogen, $16 \%$ phosphorus pentoxide, $8 \%$ potassium oxide, and $60 \%$ inert material.

17 In Vietnam, however, the trend now seems to go mostly towards 'more growth' of the economic forestry sector, which increasingly overrides/outpaces such mitigation effects [60].

18 Note that plantation programs (e.g., Program 327, which was called the 'Regreening the Bare Hills Program') often referred to 'bare hills' that needed to be 'reforested'. From an economic perspective, such descriptions ('bare hill') may not be incorrect in terms of wood production. This is, however, not in agreement with an assessment of biodiversity, because the often relatively 
species-rich 'bush' vegetation which was usually found on 'bare hills' was replaced by vegetation composed of only exotic acacia $[18,25,43,115]$.

19 Forestry literature may, for example, focus on 'sustainable management' of ecological/productive 'system units' (e.g., an acacia plot) $[44,95,129,170]$, yet largely disregard external conditions and processes. Economic literature may refer to the 'sustainability' of timber supply (or 'sustainable growth' of the wood industry sector) $[7,8,16,96]$, yet largely disregard local realities/complexities. This may cross with interpretations/perspectives of literature that focus on 'sustainable local livelihoods' $[13,53,59,171,172]$ literature which may be disinterested (or altogether discount) 'inefficiencies', or 'leverages out of poverty' through 'innovation' and developmental transitions. With regard to so-called 'sustainability', specific goals of local communities, business, and industry representatives, public policy, or development agencies thus often tug in somewhat different directions.

20 'Sustainable development' has been succinctly described by WCED [173] as "development that meets the needs of the present without compromising the ability of future generations to meet their own needs".

21 Kuhlmann \& Farrington [174] note that nowadays 'sustainability' is usually seen in three 'dimensions', namely social, economic and environmental. They point out, however, that the idea of separate 'dimensions' is a later introduction (enshrined in the UN Agenda for Development of 1997), whereas WCED [173] essentially considered the economy as integral to a single social dimension. Kuhlmann and Farrington [174] proposed societal 'well being' as a central concept for reference. This does, however, evidently not resolve complexity/diversity of different views/needs/priorities within societies.

22 Based on personal field observations by the authors during 2020 and 2021, and as can be seen from sequential images shown in Google Earth ${ }^{\mathrm{TM}}$.

23 In Vietnam further state-led tree planting campaigns are still (or again—perhaps in a somewhat different form) high on the policy agenda [199]. Within this context, the 'concept' of a 'forest transition' is increasingly referred to as a relatable form of policy objective [10] rather than as a somewhat controversial academic theory/hypothesis [200,201].

\section{References}

1. McElwee, P. Forests Are Gold: Trees, People, and Environmental Rule in Vietnam; University of Washington Press: Seattle, WA, USA, 2016.

2. Cochard, R.; Dung, T.N.; Waeber, P.O.; Kull, C.A. Extent and causes of forest cover changes in Vietnam's provinces 1993-2013: A review and analysis of official data. Environ. Rev. 2017, 25, 199-217. [CrossRef]

3. Sikor, T. Tree plantations, politics of possession and the absence of land grabs in Vietnam. J. Peasant. Stud. 2012, 39, 1077-1101. [CrossRef]

4. To, P.X.; Mahanty, S.; Wells-Dang, A.; To, D.W. From “Land to the Tiller" to the "New Landlords"? The Debate over Vietnam's Latest Land Reforms. Land 2019, 8, 120. [CrossRef]

5. Maraseni, T.N.; Hoang, L.S.; Cockfield, G.; Hung, V.D.; Tran, D.N. The financial benefits of forest certification: Case studies of acacia growers and a furniture company in Central Vietnam. Land Use Policy 2017, 69, 56-63. [CrossRef]

6. Tham, L.T.; Darr, D.; Pretzsch, J. Analysis of Acacia hybrid timber value chains: A case study of woodchip and furniture production in central Vietnam. For. Policy Econ. 2021, 125, 102401. [CrossRef]

7. Cuong, N.D.; Michael, K.; Volker, M. Land Use Spatial Optimization for Sustainable Wood Utilization at the Regional Level: A Case Study from Vietnam. Forests 2021, 12, 245. [CrossRef]

8. Nambiar, S.E.K. Strengthening Vietnam's forestry sectors and rural development: Higher productivity, value, and access to fairer markets are needed to support small forest growers. Trees For. People 2021, 3, 100052. [CrossRef]

9. Frey, G.E.; Cubbage, F.W.; Ha, T.T.T.; Davis, R.R.; Carle, J.B.; Thon, V.X.; Dzung, N.V. Financial analysis and comparison of smallholder forest and state forest enterprise plantations in Central Vietnam. Int. For. Rev. 2018, 20, 181-198. [CrossRef]

10. Van Khuc, Q.; Le, T.-A.T.; Nguyen, T.H.; Nong, D.; Bao, T.Q.; Meyfroidt, P.; Tran, T.; Duong, P.B.; Nguyen, T.T.; Tran, T.; et al. Forest Cover Change, Households' Livelihoods, Trade-Offs, and Constraints Associated with Plantation Forests in Poor Upland-Rural Landscapes: Evidence from North Central Vietnam. Forests 2020, 11, 548. [CrossRef]

11. United Nations THE 17 GOALS I Sustainable Development. Available online: https://sdgs.un.org/goals (accessed on 27 August 2021).

12. McElwee, P.; Nghi, T.H. Assessing the Social Benefits of Tree Planting by Smallholders in Vietnam: Lessons for Large-Scale Reforestation Programs. Ecol. Restor. 2021, 39, 52-63. [CrossRef]

13. Nylund, J.E.; Kröger, M. Cleavage in the understanding of sustainability: Sustainable pulp industry versus sustained local livelihoods. Scand. J. For. Res. 2012, 27, 229-240. [CrossRef]

14. Kenney-Lazar, M.; Wong, G.; Baral, H.; Russel, A.J.M. Greening rubber? Political ecologies of plantation sustainability in Laos and Myanmar. Geoforum 2018, 92, 96-105. [CrossRef]

15. $\mathrm{Xu}, \mathrm{Y}$. Politics of inclusion and exclusion in the Chinese industrial tree plantation sector: The global resource rush seen from inside China. J. Peasant. Stud. 2018, 46, 767-791. [CrossRef]

16. WWF. From Humble Beginnings in Central Vietnam, Community Leaders Create a National Model for Sustainable Forestry. 2019. Available online: https:/ / www.wwf.mg/?uNewsID=352770 (accessed on 14 May 2021).

17. Osborne, Z. In Vietnam, small farmers and timber magnates forge uneasy alliance. Mongabay. 2017. Available online: https:/ /news.mongabay.com/2017/11/in-vietnam-small-farmers-and-timber-magnates-forge-uneasy-alliance/ (accessed on 14 May 2021). 
18. Biggs, D.A. Footprints of War: Militarized Landscapes in Vietnam; University of Washington Press: Seattle, WA, USA, 2018.

19. Goscha, C. Vietnam: A New History; Basic Books: New York, NY, USA, 2016.

20. Doling, T. Exploring Hue: Heritage of the Nguyen Dynasty Heartland; The Gioi Publishers: Hanoi, Vietnam, 2018.

21. GSO. General Statistics Office of Vietnam. 2021. Available online: https://www.gso.gov.vn/en/homepage/ (accessed on 30 December 2020).

22. Nguyen, H.H.T.; Hoshino, S.; Hashimoto, S. Costs comparison between FSC and non FSC Acacia plantations in Quang Tri Province, Vietnam. Int. J. Environ. Sci. Dev. 2015, 6, 947.

23. DARD. Forestry Handbook; Department of Agriculture and Rural Development, Hue City. Transportation Publisher: Hue City, Vietnam, 2017. (In Vietnamese)

24. TTH-FOSDA. Activities of TTH-FOSDA in the Period 2016-2020; Unpublished Summary Report; Thua Thien Hue Forest Owners Sustainable Development Association: Hue City, Vietnam, 2021.

25. Biggs, D. Clearing, "Wasting," and Regreening: An Environmental History of Bare Hills in Central Vietnam. J. Asian Stud. 2018, 77, 1037-1058. [CrossRef]

26. Pietrzak, R. Forestry-Based Livelihoods in Central Vietnam: An Examination of the Acacia Commodity Chain: A Case from Thua Thien Hue Province, Vietnam. Master's Thesis, Wilfrid Laurier University, Waterloo, ON, Canada, 2010.

27. Århem, N. Forests, Spirits and High Modernist Development. A Study of Cosmology and Change among the Katuic Peoples in the Uplands of Laos and Vietnam. In Uppsala Studies in Cultural Anthropology; Acta Universitatis Upsaliensis: Uppsala, Sweden, 2014; Volume 55, 463p.

28. Hickey, G.C. Shattered World: Adaptation and Survival among Vietnam's Highland Peoples during the Vietnam War; University of Pennsylvania Press: Philadelphia, PA, USA, 1993.

29. Do, T.N.; Bruun, O. Interacting cultural and environmental change: The Co (Cua) minority of Central Vi-etnam. In On the Frontiers of Climate and Environmental Change. Vulnerabilities and Adaptations in Central Vietnam; Bruun, O., Casse, T., Eds.; Springer: Heidelberg, Germany, 2013; pp. 219-239.

30. Robert, A. Dynamiques Paysagères et Guerre Dans la Province de Thua Thien Hue (Viet Nam Central). Entre Défoliation, Déforestation et Reconquêtes Végétales. Ph.D. Thesis, Université Paris-Sorbonne, Paris, France, 2011.

31. Nguyen, T.H.V.; Kull, C. Land acquisition through Bricolage? Politics of smallholder acacia plantation expansion in upland Central Vietnam. J. Peasant. Stud. 2021. under review.

32. Baas, L. Development from Resettlement? Comparing Differences in Food Security and Coping Strategies between Resettled Households in Thua Thien-Hue Province, Vietnam. Master's Thesis, Utrecht University, Utrecht, The Netherlands, 2019.

33. Nguyen, H.T.; Pham, T.H.; De Bruyn, L.L. Impact of Hydroelectric Dam Development and Resettlement on the Natural and Social Capital of Rural Livelihoods in Bo Hon Village in Central Vietnam. Sustainability 2017, 9, 1422. [CrossRef]

34. Beckman, M. Converging and conflicting interests in adaptation to environmental change in central Vietnam. Clim. Dev. 2011, 3, 32-41. [CrossRef]

35. McElwee, P. Shifting justifications: An environmental history of combatting swidden cultivation in Vietnam. J. Southeast Asian Stud. 2021. under review.

36. Nguyen, T.T.P.; Masuda, M.; Iwanaga, S. The effect of forestland allocation to the livelihoods of local people in the North Central Coast of Vietnam: A case in Nam Dong district. Tropics 2016, 24, 169-180. [CrossRef]

37. Bayrak, M.M.; Tran, N.T.; Burgers, P. Restructuring space in the name of development: The sociocultural impact of the Forest Land Allocation Program on the indigenous Co Tu people in Central Vietnam. J. Political Ecol. 2015, 20, 37-52. [CrossRef]

38. Bayrak, M.M.; Tran, N.T.; Burgers, P. Formal and indigenous forest management systems in Central Vietnam. Implications and challenges for REDD+. In Shifting Cultivation and Environmental Change: Indigenous People, Agriculture and Forest Conservation; Cairns, M.F., Ed.; Routledge: Abingdon, UK, 2015; pp. 319-334.

39. Jakobsen, J.; Rasmussen, K.; Leisz, S.; Folving, R.; Quang, N.V. The effects of land tenure policy on rural livelihoods and food sufficiency in the upland village of Que, North Central Vietnam. Agric. Syst. 2007, 94, 309-319. [CrossRef]

40. Le, L.T.H.; Dat, N.D.; Minh, N.H.; Nguyen, K.-A. Characteristics of PCDD/Fs in soil and sediment samples collected from A-So former airbase in Central Vietnam. Sci. Total. Environ. 2019, 661, 27-34. [CrossRef] [PubMed]

41. Biggs, D. Frame DS1050-1006DF129: 20 March 1969. Environ. Hist. 2014, 19, 271-280. [CrossRef]

42. Tran, D.; Rambo, A.T.; Nguyen, T.L. Farming with Fire and Water: The Human Ecology of a Composite Swiddening Community in Vietnam's Northern Mountains; Kyoto University Press: Kyoto, Japan, 2009.

43. McElwee, P. Reforesting "bare hills" in Vietnam: Social and environmental consequences of the 5 million hectare re-forestation program. Ambio 2009, 38, 325-333. [CrossRef]

44. Nambiar, S.E.K.; Harwood, C.E.; Nguyen, D.K. Acacia plantations in Vietnam: Research and knowledge application to secure a sustainable future. South. For. 2015, 77, 1-10. [CrossRef]

45. Koutika, L.-S.; Richardson, D.M. Acacia mangium Willd: Benefits and threats associated with its increasing use around the world. For. Ecosyst. 2019, 6, 2. [CrossRef]

46. Le, D.K.; Ha, H.T. Research and development of acacia hybrids for commercial planting in Vietnam. Vietnam. J. Sci. Technol. Eng. 2017, 59, 36-42. [CrossRef]

47. Cuong, T.; Chinh, T.T.Q.; Zhang, Y.; Xie, Y. Economic Performance of Forest Plantations in Vietnam: Eucalyptus, Acacia mangium, and Manglietia conifera. Forests 2020, 11, 284. [CrossRef] 
48. Dang, T.K.P.; Turnhout, E.; Arts, B. Changing forestry discourses in Vietnam in the past 20 years. For. Policy Econ. $2012,25,31-41$. [CrossRef]

49. De Jong, W.; Do Dinh, S.; Trieu, V.H. Forest Rehabilitation in Vietnam. Histories, Realities and Future; Center for International Forestry Research (CIFOR): Bogor, Indonesia, 2006.

50. Ohlsson, B.; Sandewall, M.; Sandewall, R.K.; Nguyen, H.P. Government plans and farmers' intentions: A study on forest land use planning in Vietnam. Ambio 2005, 34, 248-255. [CrossRef]

51. Sam, D.D.; van Hung, T.; Mau, M.P.N.; De Jong, W. Review of Forest Rehabilitation Initiatives in Vietnam; Project Report Phase 1; Forest Science Institute of Vietnam and Center for International Forest Research: Hanoi, Vietnam, 2004.

52. Iwanaga, S.; Duong, D.T.; van Minh, N. Impact of policies on raw material procurement in the Vietnamese timber processing industry: A case study of sawmills in Hue City. J. For. Res. 2020, 25, 59-68. [CrossRef]

53. Thulstrup, A.W. Livelihood resilience and adaptive capacity: Tracing changes in household access to capital in Central Vietnam. World Dev. 2015, 74, 352-362. [CrossRef]

54. Sandewall, M.; Ohlsson, B.; Sandewall, R.K.; Viet, L.S. The expansion of farm-based plantation forestry in Vietnam. Ambio 2010, 39, 567-579. [CrossRef]

55. Van den Broeck, K.; Tarp, F.; Markussen, T. The Forgotten Property Rights: Restrictions on Land Use in Vietnam; University of Copenhagen: Copenhagen, Denmark, 2009.

56. Haas, J.C.; Loft, L.; Pham, T.T. How fair can incentive-based conservation get? The interdependence of distributional and contextual equity in Vietnam's Payments for Forest Environmental Services Program. Ecol. Econ. 2019, 160, 205-214. [CrossRef]

57. Tham, L.T.; Darr, D.; Pretzsch, J. Contribution of small-scale acacia hybrid timber production and commercialization for livelihood development in Central Vietnam. Forests 2020, 11, 1335. [CrossRef]

58. Kim, C.V.; van Rompaey, A.; Govers, G.; Vanacker, V.; Schmook, B.; Nguyen, H. Land transitions in Northwest Vietnam: An integrated analysis of bio-physical and socio-cultural factors. Hum. Ecol. 2013, 41, 37-50.

59. Thulstrup, A.W.; Casse, T.; Nielsen, T.T. The Push for Plantations: Drivers, Rationales and Social Vulnerability in Quang Nam Province, Vietnam. In On the Frontiers of Climate and Environmental Change. Vulnerabilities and Adaptations in Central Vietnam; Bruun, O., Casse, T., Eds.; Springer: Heidelberg, Germany, 2013; pp. 71-89.

60. Cochard, R.; Nguyen, V.H.T.; Dung, T.N.; Kull, C.A. Vietnam's forest cover changes 2005-2016: Veering from transition to (yet more) transaction? World Dev. 2020, 135, 10501. [CrossRef]

61. Van, Y.T.; Cochard, R. Tree species diversity and utilities in a contracting lowland hillside rainforest fragment in Central Vietnam. For. Ecosyst. 2017, 4, 1-19. [CrossRef]

62. Arvola, A.; Brockhaus, M.; Kallio, M.; Pham, T.T.; Chi, D.T.L.; Long, H.T.; Nawir, A.A.; Phimmavong, S.; Mwamakimbullah, R.; Jacovelli, P. What drives smallholder tree growing? Enabling conditions in a changing policy environment. For. Policy Econ. 2020, 116, 102173. [CrossRef]

63. Bayrak, M.M. State forest governance in Vietnam: Where are the local communities? In Population, Development, and the Environment; James, H., Ed.; Palgrave Macmillan: Singapore, 2019; pp. 273-295.

64. Asia Perspective. Vietnam's Export of Wood and Wooden Furniture Recovers after COVID-19. 2020. Available online: https: / /asiaperspective.net/2020/12/22/vietnam-export-wood-wooden-furniture-recovers-covid-19/ (accessed on 10 May 2021).

65. To, P.X.; Cao, C.T.; le Tran, H. Vietnam Imports and Exports Wood and Wood Products: Current Situation in 2019 and Trends in 2020; Forest Trends: Washinton, DC, USA, 2020; Available online: https://goviet.org.vn/upload/aceweb/content/Vietnam\%202019 \%20report.pdf (accessed on 15 May 2021). (In Vietnamese)

66. North, J. Vietnam: World Woodchip Champion. Vietnam's Hardwood Chips Power Asia's Pulp Mills, but Supply Is Under Stress; Fastmarkets RISI: Boston, MA, USA, 2019; Available online: https://insights.risiinfo.com/vietnam-hardwood-chip-exports/ index.html\#section-UXmdddCgln (accessed on 11 May 2021).

67. Tatarski, M. Coronavirus Outbreak hits Vietnam's Timber Sector. Mongabay. 2020. Available online: https://news.mongabay. com/2020/02/ coronavirus-outbreak-hits-vietnams-timber-sector/ (accessed on 10 May 2021).

68. Phong, T.D. Export of Woodchips: Leading the World, But not in Charge. 2019. Available online: http:/ / songhanhexport.com. vn/export-of-woodchips-leading-the-world-but-not-in-charge (accessed on 10 May 2021).

69. Norman, M. Trends in Timber Product Exports and Imports from Vietnam and the Mekong Region; Forest Trends: Washington, DC, USA, 2016; Available online: https://www.forest-trends.org/wp-content/uploads/imported/vietnam-and-mekong-export-and-importtrends_marigold-norman-forest-trends-pdf.pdf (accessed on 14 May 2021).

70. Meyfroidt, P.; Lambin, E.F. Forest transition in Vietnam and displacement of deforestation abroad. Proc. Natl. Acad. Sci. USA 2009, 106, 16139-16144. [CrossRef]

71. To, P.X.; Mahanty, S. Vietnam's cross-border timber crackdown and the quest for state legitimacy. Political Geogr. 2019, 75, 102066. [CrossRef]

72. Roe, B.; Eastin, I.; Ganguly, I. The impact of timber legality regulations on business practices in Vietnam. For. Chron. 2014, 90, 651-659. [CrossRef]

73. MARD. Forest Sector Development Program; Ministry of Agriculture and Rural Development: Hanoi, Vietnam, 2015.

74. Quang, N.V.; Phuc, T.X.; Treanor, B.N.; Quyen, N.T.; Cam, C.T. Linking Smallholder Plantations to Global Markets: Lessons from the IKEA Model in Vietnam; Forest Trends: Washington, DC, USA, 2018; Available online: https://mrlg.org/wp-content/uploads/20 19/06/IKEA-case-study-15-June_Final.pdf (accessed on 20 May 2021). 
75. Hoang, H.T.N.; Hashino, S.; Onitsuka, K.; Maraseni, T. Cost analysis of FSC forest certification and opportunities to cover the costs: A case study of Quang Tri FSC group in Central Vietnam. J. For. Res. 2018, 24, 137-142. [CrossRef]

76. Pistorius, T.; Hoang, H.D.T.; Tennigkeit, T.; Merger, E.; Wittmann, N.; Conway, D. Business Models for the Restoration of ShortRotation Acacia Plantations in Vietnam. A Project Supported by the German International Climate Initiative; UNIQUE Forestry Land Use: Freiburg im Breisgau, Germany, 2016; Available online: https://www.unique-landuse.de/images/publications/vereinheitlicht/ Acacia-Business-Models-Vietnam.pdf (accessed on 11 May 2021).

77. Crowther, J.; Zimmer, H.; Le Thi, H.; Quang, T.L.; Nichols, J.D. Forestry in Vietnam: The potential role for native timber species. For. Policy Econ. 2020, 116, 102182. [CrossRef]

78. Hardiyanto, E.B.; Nambiar, E.K.S. Productivity of successive rotations of Acacia mangium plantations in Sumatra, Indonesia: Impacts of harvest and inter-rotation site management. New For. 2014, 45, 557-575. [CrossRef]

79. Midgley, S.J.; Stevens, P.R.; Arnold, R.J. Hidden assets: Asia's smallholder wood resources and their contribution to supply chains of commercial wood. Aust. For. 2017, 80, 10-25. [CrossRef]

80. FSC. The FSC National Forest Stewardship Standard of Vietnam; FSC International Center, Performance and Standards Unit. Forest Stewardship Council: Bonn, Germany, 2018.

81. van Noordwijk, M.; Leimona, B. Eco-certification and the commoditization of ecosystem services. In Co-Investment in Ecosystem Services: Global Lessons from Payment and Incentive Schemes; Namirembe, S., Leimona, B., van Noordwijk, M., Minang, P., Eds.; World Agroforestry Centre (ICRAF): Nairobi, Kenya, 2017; pp. 1-15.

82. Pirard, R.; Dal Secco, L.; Warman, R. Do timber plantations contribute to forest conservation? Environ. Sci. Policy 2016, 57, 122-130. [CrossRef]

83. Rahman, S.A.; Jacobsen, J.B.; Healey, J.R.; Roshetko, J.M.; Sunderland, T. Finding alternatives to swidden agriculture: Does agroforestry improve livelihood options and reduce pressure on existing forest? Agrofor. Syst. 2016, 91, 185-199. [CrossRef]

84. Salignac, F.; Bhatia, B.; Tallontire, A. The nature of fair trade exchanges and their outcomes: Producer voices in Vietnam and India. Bus. Strat. Dev. 2021, 1-12. [CrossRef]

85. Hoang, H.T.N.; Hoshino, S.; Hashimoto, S. Forest stewardship council certificate for a group of planters in Vietnam: SWOT analysis and implications. J. For. Res. 2015, 20, 35-42. [CrossRef]

86. Auer, M.R. Group Forest Certification for Smallholders in Vietnam: An Early Test and Future Prospects. Hum. Ecol. 2012, 40, 5-14. [CrossRef]

87. Gerber, J.-F. Conflicts over industrial tree plantations in the South: Who, how and why? Glob. Environ. Chang. 2011, 21, 165-176. [CrossRef]

88. Flanagan, A.C.; Midgley, S.J.; Stevens, P.R. Smallholder tree farmers and forest certification in Southeast Asia: Alternative approaches to deliver more benefits to growers. Aust. For. 2020, 83, 52-65. [CrossRef]

89. Malkamäki, A.; D'Amato, D.; Hogarth, N.; Kanninen, M.; Pirard, R.; Toppinen, A.; Zhou, W. A systematic review of the socio-economic impacts of large-scale tree plantations, worldwide. Glob. Environ. Chang. 2018, 53, 90-103. [CrossRef]

90. Villamor, G.B.; Catacutan, D.C.; Truong, V.A.T.; Thi, L.D. Tree-cover transition in Northern Vietnam from a gender-specific land-use preferences perspective. Land Use Policy 2017, 61, 53-62. [CrossRef]

91. Richards, M. Gender and Wood-Based Value Chains in Vietnam; Forest Trend: Hanoi, Vietnam, 2019.

92. Poynton, S. Beyond Certification; Dō Sustainability: Oxford, UK, 2015.

93. Mithöfer, D.; van Noordwijk, M.; Leimona, B.; Cerutti, P.O. Certify and shift blame, or resolve issues? Environmentally and socially responsible global trade and production of timber and tree crops. Int. J. Biodivers. Sci. Ecosyst. Serv. Manag. 2016, 13, 72-85. [CrossRef]

94. Dupuis, E.M.; Ball, T. How not what: Teaching sustainability as process. Sustain. Sci. Pr. Policy 2013, 9, 64-75. [CrossRef]

95. Van Bich, N. Inter-Rotational Strategies for Sustaining Site Fertility and Productivity of Acacia and Eucalyptus Plantations Planted on Steep Slopes in Northern Vietnam. Ph.D. thesis, University of Tasmania, Hobart, Australia, 2019.

96. Nambiar, S.E.K.; Harwood, C.E.; Mendham, D.S. Paths to sustainable wood supply to the pulp and paper industry in Indonesia after diseases have forced a change of species from acacia to eucalypts. Aust. For. 2018, 81, 148-161. [CrossRef]

97. Lee, S.S. Observations on the successes and failures of acacia plantations in Sabah and Sarawak and the way forward. J. Trop. For. Sci. 2018, 30, 468-475. [CrossRef]

98. Thu, P.Q.; Griffiths, M.W.; Pegg, G.S.; McDonald, J.M.; Wylie, F.R.; King, J.; Lawson, S.A. Healthy Plantations: A Field Guide to Pests and Pathogens of Acacia, Eucalyptus and Pinus in Vietnam; Department of Employment, Economic Development and Innovation: Queensland, Australia, 2010.

99. Harwood, C.E.; Nambiar, E.K.S.; Dinh, P.X.; Toan, L.X.; Quang, L.T. Managing wood production from small grower acacia hybrid plantations on eroded soils in central Vietnam. Aust. For. 2017, 80, 286-293. [CrossRef]

100. Locatelli, T.; Nicoll, B. Wind Damage Risk for Acacia Plantations in Thua Thien Hue Province of Vietnam; UNIQUE Forestry and Land Use: Freiburg im Breisgau, Germany, 2017; Available online: https://www.unique-landuse.de/images/publications / vereinheitlicht/2017-09_Wind_Study_Vietnam_final.pdf (accessed on 14 May 2021).

101. Zhunusova, E.; Sen, L.T.H.; Schröder, J.-M.; Le, T.H.S.; Dieter, M.; Günter, S. Smallholder Decision-Making on Sawlog Production: The Case of Acacia Plantation Owners in Central Vietnam. Forests 2019, 10, 969. [CrossRef]

102. TTH-FOSDA. Activities of TTH-FOSDA in the Period 2016-2018; Unpublished summary report; Thua Thien Hue Forest Owners Sustainable Development Association: Hue City, Vietnam, 2018. 
103. Bryman, A. Social Research Methods; Oxford University Press: Oxford, UK, 2016.

104. Van, D.N.; Son, C.T.; Hung, L. Ethnic Minorities in Vietnam; The Gioi Publishers: Hanoi, Vietnam, 2016.

105. Nguyen, L.D.; Raabe, K.; Grote, U. Rural-urban migration, household vulnerability, and welfare in Vietnam. World Dev. 2013, 71, 79-93. [CrossRef]

106. Epprecht, M.; Müller, D.; Minot, N. How remote are Vietnam's ethnic minorities? An analysis of spatial patterns of poverty and inequality. Ann. Reg. Sci. 2009, 46, 349-368. [CrossRef]

107. Le, H.D.; Tran, T.M.A.; Pham, H.T. Key factors influencing forest tree planting decisions of households: A case study in Hoa Binh province, Vietnam. For. Trees Livelihoods 2020, 30, 57-73. [CrossRef]

108. Dinh, H.H.; Nguyen, T.T.; Hoang, V.-N.; Wilson, C. Economic incentive and factors affecting tree planting of rural households: Evidence from the Central Highlands of Vietnam. J. For. Econ. 2017, 29, 14-24. [CrossRef]

109. Clement, F.; Amezaga, J.M. Linking reforestation policies with land use change in northern Vietnam: Why local factors matter. Geoforum 2008, 39, 265-277. [CrossRef]

110. Voigtlaender, M.; Laclau, J.-P.; Gonçalves, J.L.M.; Piccolo, M.C.; Moreira, M.Z.; Nouvellon, Y.; Ranger, J.; Bouillet, J.-P. Introducing Acacia mangium trees in Eucalyptus grandis plantations: Consequences for soil organic matter stocks and nitrogen mineralization. Plant Soil 2012, 352, 99-111. [CrossRef]

111. Booth, T.H.; Jovanovic, T.; Old, K.M.; Dudzinski, M.J. Climatic mapping to identify high-risk areas for Cylindrocladium quinqueseptatum leaf blight on eucalypts in mainland South East Asia and around the world. Environ. Pollut. 2000, 108, 365-372. [CrossRef]

112. Sang, P.M.; Lamb, M.; Schmidt, S. Carbon sequestration and soil fertility of tropical tree plantations and secondary forest established on degraded land. Plant Soil 2013, 362, 187-200. [CrossRef]

113. Nambiar, S.E.K.; Harwood, C.E. Productivity of acacia and eucalypt Plantations in Southeast Asia. 1. Bio-physical determinants of production: Opportunities and challenges. Int. For. Rev. 2014, 16, 225-247. [CrossRef]

114. DARD. Some Results of the Forest Sector Development Project-DAWB3; Department of Agriculture and Rural: Hue City, Vietnam, 2014. Available online: https: / / snnptnt.thuathienhue.gov.vn/?gd=20\&cn=1\&id=492\&tc=218 (accessed on 14 July 2021). (In Vietnamese)

115. Nikolic, N.; Schultze-Kraft, R.; Nikolic, M.; Böcker, R.; Holz, I. Land Degradation on Barren Hills: A Case Study in Northeast Vietnam. Environ. Manag. 2008, 42, 19-36. [CrossRef] [PubMed]

116. Woo, S.Y.; Thai, H.T.; Park, P.S. Stand structure and natural regeneration of degraded forestland in the northern mountainous region of Vietnam. Landsc. Ecol. Eng. 2010, 7, 251-261. [CrossRef]

117. Rerkasem, K.; Lawrence, D.; Padoch, C.; Schmidt-Vogt, D.; Ziegler, A.D.; Bruun, T.B. Consequences of Swidden Transitions for Crop and Fallow Biodiversity in Southeast Asia. Hum. Ecol. 2009, 37, 347-360. [CrossRef]

118. McElwee, P. You Say Illegal, I Say Legal. J. Sustain. For. 2004, 19, 97-135. [CrossRef]

119. Maraseni, T.N.; Son, H.L.; Cockfield, G.; Duy, H.V.; Nghia, T.D. Comparing the financial returns from acacia plantations with different plantation densities and rotation ages in Vietnam. For. Policy Econ. 2017, 83, 80-87. [CrossRef]

120. Blackburn, D.; Huong, V.D.; Thanh, N.D.; Mendham, D. Solid wood property variations in early-age Acacia plantation trees grown in southern Vietnam. South. For. J. For. Sci. 2021, 83, 19-27. [CrossRef]

121. Sikor, T.; Baggio, J. Can Smallholders Engage in Tree Plantations? An Entitlements Analysis from Vietnam. World Dev. 2014, 64 (Suppl. S1), S101-S112. [CrossRef]

122. Huizinga, M. Impact of Forest Land Allocation on Rural Livelihoods of Katu and Kinh Households in Nam Dong district, Central Vietnam. Master's Thesis, Utrecht University, Utrecht, The Netherlands, 2012.

123. Permadi, D.B.; Burton, M.; Pandit, R.; Race, D.; Ma, C.; Mendham, D.; Hardiyanto, E.B. Socio-economic factors affecting the rate of adoption of acacia plantations by smallholders in Indonesia. Land Use Policy 2018, 76, 215-223. [CrossRef]

124. Nguyen, H.T.; Ariyawardana, A.; Ratnasiri, S. Forest plantation owners' willingness to pay for hybrid nursery stock: The case of Acacia hybrids in Central Vietnam. For. Policy Econ. 2020, 116, 102184. [CrossRef]

125. Saharjo, B.H.; Watanabe, H. Estimation of litter fall and seed production of Acacia mangium in a forest plantation in South Sumatra, Indonesia. For. Ecol. Manag. 2000, 130, 265-268. [CrossRef]

126. Harwood, C.E.; Hardiyanto, E.B.; Yong, W.C. Genetic improvement of tropical acacias: Achievements and challenges. South. For. 2015, 77, 11-18. [CrossRef]

127. Hung, T.T.; Almeida, A.C.; Eyles, A.; Mohammed, C. Predicting productivity of Acacia hybrid plantations for a range of climates and soils in Vietnam. For. Ecol. Manag. 2016, 367, 97-111. [CrossRef]

128. Beadle, C.L.; Trieu, D.T.; Harwood, C.E. Thinning increases sawlog values in fast-growing plantations of acacia hybrid in Vietnam. J. Trop. For. Sci. 2013, 25, 42-51.

129. Huong, V.D.; Nambiar, E.S.; Quang, L.T.; Mendham, D.S.; Dung, P.T. Improving productivity and sustainability of successive rotations of Acacia auriculiformis plantations in South Vietnam. South. For. 2015, 77, 51-58. [CrossRef]

130. Huong, V.D.; Mendham, D.S.; Close, D.C. Growth and physiological responses to intensity and timing of thinning in short rotation tropical Acacia hybrid plantations in South Vietnam. For. Ecol. Manag. 2016, 380, 233-241. [CrossRef]

131. Blackburn, D.; Huong, V.D.; Mendham, D. Returns to Vietnamese smallholder farmers from managing acacia plantations for sawn wood over 4-10 year rotations. For. Policy Econ. 2020, 121, 102318. [CrossRef] 
132. Huong, V.D.; Nambiar, E.K.S.; Hai, N.X.; Ha, K.M.; Van Dang, N. Sustainable Management of Acacia auriculiformis Plantations for Wood Production over Four Successive Rotations in South Vietnam. Forests 2020, 11, 550. [CrossRef]

133. Chi, N.M.; Thu, P.Q.; Hinh, T.X.; Dell, B. Management of Ceratocystis manginecans in plantations of Acacia through optimal pruning and site selection. Australas. Plant Pathol. 2019, 48, 343-350. [CrossRef]

134. Harwood, C.E.; Nambiar, E.K.S. Sustainable Plantation Forestry in South-East Asia; Australian Centre for International Agricultural Research, ACIAR Monograph: Canberra, Australia, 2014.

135. Wang, F.; Zou, B.; Li, H.; Li, Z. The effect of understory removal on microclimate and soil properties in two sub-tropical lumber plantations. J. For. Res. 2013, 19, 238-243. [CrossRef]

136. Xiong, Y.; Xia, H.; Li, Z.; Cai, X.; Fu, S. Impacts of litter and understory removal on soil properties in a subtropical Acacia mangium plantation in China. Plant Soil 2008, 304, 179-188. [CrossRef]

137. Thanh, V.D.T. Role of middlemen in the supply of the processing industry in the Central South region of Vietnam. Cah. Agric. 2009, 18, 329-336.

138. Hung, T.T.; Doyle, R.; Eyles, A.; Mohammed, C. Comparison of soil properties under tropical Acacia hybrid plantation and shifting cultivation land use in northern Vietnam. South. For. J. For. Sci. 2016, 79, 9-18. [CrossRef]

139. Dong, T.L.; Doyle, R.; Beadle, C.L.; Corkrey, S.; Quat, N.X. Impact of short-rotation Acacia hybrid plantations on soil properties of degraded lands in Central Vietnam. Soil Res. 2014, 52, 271-281. [CrossRef]

140. Wang, F.; Li, Z.; Xia, H.; Zou, B.; Li, N.; Liu, J.; Zhu, W. Effects of nitrogen-fixing and non-nitrogen fixing tree species on soil properties and nitrogen transformation during forest restoration in southern China. Soil Sci. Plant Nutr. 2010, 56, 297-306. [CrossRef]

141. Schiavo, J.A.; Busato, J.G.; Martins, M.A.; Canellas, L.P. Recovery of degraded areas revegetated with Acacia mangium and Eucalyptus with special reference to organic matter humification. Sci. Agrícola 2009, 66, 353-360. [CrossRef]

142. Bruun, T.B.; de Neergaard, A.; Lawrence, D.; Ziegler, A.D. Environmental Consequences of the Demise in Swidden Cultivation in Southeast Asia: Carbon Storage and Soil Quality. Hum. Ecol. 2009, 37, 375-388. [CrossRef]

143. Yamashita, N.; Ohta, S.; Hardjono, A. Soil changes induced by Acacia mangium plantation establishment: Comparison with secondary forest and Imperata cylindrica grassland soils in South Sumatra, Indonesia. For. Ecol. Manag. 2008, 254, 362-370. [CrossRef]

144. Dubiez, E.; Freycon, V.; Marien, J.-N.; Peltier, R.; Harmand, J.-M. Long term impact of Acacia auriculiformis woodlots growing in rotation with cassava and maize on the carbon and nutrient contents of savannah sandy soils in the humid tropics (Democratic Republic of Congo). Agrofor. Syst. 2019, 93, 1167-1178. [CrossRef]

145. Sidle, R.C.; Ziegler, A.D.; Negishi, J.N.; Nik, A.R.; Siew, R.; Turkelboom, F. Erosion processes in steep terrain-Truths, myths, and uncertainties related to forest management in Southeast Asia. For. Ecol. Manag. 2006, 224, 199-225. [CrossRef]

146. Cochard, R. Natural hazards mitigation services of carbon-rich ecosystems. In Ecosystem Services and Carbon Sequestration in the Biosphere; Lal, R., Lorenz, K., Hüttl, R.F., Schneider, B.U., von Braun, J., Eds.; Springer: Heidelberg, Germany, 2013; Chapter 11; pp. 221-293. [CrossRef]

147. Sun, D.; Zhang, W.; Lin, Y.; Liu, Z.; Shen, W.; Zhou, L.; Rao, X.; Liu, S.; Cai, X.-A.; He, D.; et al. Soil erosion and water retention varies with plantation type and age. For. Ecol. Manag. 2018, 422, 1-10. [CrossRef]

148. Podwojewski, P.; Orange, D.; Jouquet, P.; Valentin, C.; Nguyen, V.T.; Janeau, J.; Tran, D.T. Land-use impacts on surface runoff and soil detachment within agricultural sloping lands in Northern Vietnam. Catena 2008, 74, 109-118. [CrossRef]

149. Dung, B.X.; Kolyan, C.; Linh, N.T.M.; Ravor, S. Runoff Generation and Soil Erosion at Different Age of Acacia Plantation in Hoa Binh Province, Vietnam. VNU J. Sci. Earth Environ. Sci. 2019, 35. [CrossRef]

150. Dung, B.X.; Kim, T.D.T. Runoff and soil erosion response to clear cutting period of acacia plantation in a headwater mountain of Vietnam. Appl. Res. Sci. Technol. 2021, 1, 12-25.

151. Malmer, A. Hydrological effects and nutrient losses of forest plantation establishment on tropical rainforest land in Sabah, Malaysia. J. Hydrol. 1996, 174, 129-148. [CrossRef]

152. Pham, N.T.T.; Nguyen, H.Q.; Ngo, A.D.; Le, H.T.T.; Nguyen, C.T. Investigating the impacts of typhoon-induced floods on the agriculture in the central region of Vietnam by using hydrological models and satellite data. Nat. Hazards 2018, 92, 189-204. [CrossRef]

153. Van Bich, N.; Mendham, D.; Evans, K.J.; Dong, T.L.; Vo Dai, H.; van Thanh, H.; Mohammed, C.L. Effect of residue management and fertilizer application on the productivity of a Eucalyptus hybrid and Acacia mangium planted on sloping terrain in northern Vietnam. South. For. 2019, 81, 201-212. [CrossRef]

154. Mendham, D.S.; White, D.A. A review of nutrient, water and organic matter dynamics of tropical acacias on mineral soils for improved management in Southeast Asia. Aust. For. 2019, 82 (Suppl. S1), 45-56. [CrossRef]

155. Van Do, T.; Thang, N.T.; Lam, V.T.; Van Thuyet, D.; Trung, P.D.; Quy, T.H.; Phuong, N.T.T.; Huyen, L.T.T.; Thinh, N.H.; Van Tuan, N.; et al. Monitoring fine root growth to identify optimal fertilization timing in a forest plantation: A case study in Northeast Vietnam. PLoS ONE 2019, 14, e0225567. [CrossRef]

156. Saharjo, B.H. The effects of fire on the properties of soil in Acacia mangium plantations in South Sumatra, Indonesia. J. Trop. For. Sci. 1999, 11, 459-469.

157. Cochard, R.; Van, Y.T.; Ngo, D.T. Determinants and correlates of above-ground biomass in a secondary hillside rainforest in Central Vietnam. New For. 2018, 49, 429-455. [CrossRef] 
158. Thang, N.T.; Lam, V.T.; Son, N.H.; Van Do, T.; Van Thuyet, D.; Trung, P.D.; Sam, P.D.; Quy, T.H.; Phuong, N.T.T.; Huyen, L.T.T.; et al. Changes in fine root growth dynamics in response to phosphorus application in an Acacia mangium plantation in Vietnam. New For. 2019, 51, 835-847. [CrossRef]

159. Mendham, D.S.; Hardiyanto, E.B.; Wicaksono, A.; Nurudin, M. Nutrient management of contrasting Acacia mangium genotypes and weed management strategies in South Sumatra, Indonesia. Aust. For. 2017, 80, 127-134. [CrossRef]

160. Amat, J.P.; Tuu, B.P.; Robert, A.; Huu, N.T. Can fast-growing species form high-quality forests in Vietnam? Examples in Thua Thien-Hue province. Bois Forêts Trop. 2010, 305, 67-76. [CrossRef]

161. Giardina, C.P.; Sanford, R.; Døckersmith, I.C.; Jaramillo, V.J. The effects of slash burning on ecosystem nutrients during the land preparation phase of shifting cultivation. Plant Soil 2000, 220, 247-260. [CrossRef]

162. Cordell, D.; White, S. Life's Bottleneck: Sustaining the World's Phosphorus for a Food Secure Future. Annu. Rev. Environ. Resour. 2014, 39, 161-188. [CrossRef]

163. To, P.X.; Mahanty, S.; Dressler, W.H. 'A new landlord' (địa chủ mới)? Community, land conflict and State Forest Companies (SFCs) in Vietnam. For. Policy Econ. 2015, 58, 21-28. [CrossRef]

164. To, P.; Dressler, W.; Mahanty, S. REDD+ for Red Books? Negotiating rights to land and livelihoods through carbon governance in the Central Highlands of Vietnam. Geoforum 2017, 81, 163-173. [CrossRef]

165. To, P.X.; Dressler, W. Rethinking 'success': The politics of payment for forest ecosystem services in Vietnam. Land Use Policy 2019, 81, 582-593. [CrossRef]

166. Mertz, O.; Mertens, C.F. Land Sparing and Land Sharing Policies in Developing Countries—Drivers and Linkages to Scientific Debates. World Dev. 2017, 98, 523-535. [CrossRef]

167. Nájera, A.; Simonetti, J.A. Enhancing Avifauna in Commercial Plantations. Conserv. Biol. 2010, 24, 319-324. [CrossRef]

168. Ramírez, P.A.; Simonetti, J.A. Conservation opportunities in commercial plantations: The case of mammals. J. Nat. Conserv. 2011, 19, 351-355. [CrossRef]

169. Millan, C.H.; Develey, P.F.; Verdade, L.M. Stand-level management practices increase occupancy by birds in exotic Eucalyptus plantations. For. Ecol. Manag. 2015, 336, 174-182. [CrossRef]

170. Wiersum, K.F. 200 years of sustainability in forestry: Lessons from history. Environ. Manag. 1995, 19, 321-329. [CrossRef]

171. Kyeyune, V.; Turner, S. Yielding to high yields? Critiquing food security definitions and policy implications for ethnic minority livelihoods in upland Vietnam. Geoforum 2016, 71, 33-43. [CrossRef]

172. Trædal, L.T.; Vedeld, P. Cultivating forests: The role of forest land in household livelihood adaptive strategies in the Bac Kan Province of northern Vietnam. Land Use Policy 2018, 73, 249-258. [CrossRef]

173. WCED. Our Common Future. World Commission on Environment and Development (WCED); Oxford University Press: Oxford, UK, 1987.

174. Kuhlmann, T.; Farrington, J. What is sustainability? Sustainability 2010, 2, 3436-3448. [CrossRef]

175. Dong, T.L. Using Acacia as a nurse crop for re-establishing native-tree species plantation on degraded lands in Vietnam. Ph.D. Thesis, University of Tasmania, Hobart, Australia, 2014.

176. McNamara, S.; Tinh, D.V.; Erskine, P.D.; Lamb, D.; Yates, D.; Brown, S. Rehabilitating degraded forest land in central Vietnam with mixed native species plantings. For. Ecol. Manag. 2006, 233, 358-365. [CrossRef]

177. Kuusipalo, J.; Ådjers, G.; Jafarsidik, Y.; Otsamo, A.; Tuomela, K.; Vuokko, R. Restoration of natural vegetation in degraded Imperata cylindrica grassland: Understorey development in forest plantations. J. Veg. Sci. 1995, 6, 205-210. [CrossRef]

178. Wong, G.Y.; Moeliono, M.; Bong, I.W.; Pham, T.T.; Sahide, M.A.K.; Naito, D.; Brockhaus, M. Social forestry in Southeast Asia: Evolving interests, discourses and the many notions of equity. Geoforum 2020, 117, 246-258. [CrossRef]

179. Vera, F. The shifting baseline syndrome in restoration ecology. In Restoration and History. The Search for a Usable Environmental past; Hall, M., Ed.; Routledge: Abingdon, UK, 2009.

180. Cochard, R. Consequences of deforestation and climate change on biodiversity. In Land Use, Climate Change and Biodiversity Modeling: Perspectives and Applications; Trisurat, Y., Shrestha, R., Alkemade, R., Eds.; IGI Global: Hershey, PA, USA, 2011; Chapter 2; pp. 30-55.

181. Nasution, A.; Glen, M.; Beadle, C.; Mohammed, C. Ceratocystis wilt and canker-a disease that compromises the growing of commercial Acacia-based plantations in the tropics. Aust. For. 2019, 82 (Suppl. S1), 80-93. [CrossRef]

182. Teshome, D.T.; Zharare, G.E.; Naidoo, S. The Threat of the Combined Effect of Biotic and Abiotic Stress Factors in Forestry Under a Changing Climate. Front. Plant Sci. 2020, 11. [CrossRef] [PubMed]

183. Liebhold, A.M. Forest pest management in a changing world. Int. J. Pest Manag. 2012, 58, 289-295. [CrossRef]

184. Van, D.T.; Lee, D.K.; Van, T.H. Rehabilitation of the native tree species in the forest plantations and denuded hills of Namlau commune in Sonla province, Vietnam. For. Sci. Technol. 2005, 1, 51-58. [CrossRef]

185. Van Tien, P.; Trinh, P.T.; Luong, L.H.; Nhat, L.M.; Duc, D.M.; Hieu, T.T.; Cuong, T.Q.; Nhan, T.T. The 13 October 2020, deadly rapid landslide triggered by heavy rainfall in Phong Dien, Thua Thien Hue, Vietnam. Landslides 2021, 18, 2329-2333. [CrossRef]

186. Gia, C. Deforestation, Construction to Blame for Central Vietnam Landslides. VN Express International. 2020. Available online: https:/ / e.vnexpress.net/news/news/deforestation-construction-to-blame-for-central-vietnam-landslides-4185723.html (accessed on 11 August 2021).

187. Tran, P.; Shaw, R. Towards an integrated approach of disaster and environment management: A case study of Thua Thien Hue province, central Viet Nam. Environ. Hazards 2007, 7, 271-282. [CrossRef] 
188. Thu, T.P.; Moeliono, M.; Wong, G.; Brockhaus, M.; Dung, L.N. The politics of swidden: A case study from Nghe An and Son La in Vietnam. Land Use Policy 2018, 99, 103050. [CrossRef]

189. Ziegler, A.D.; Bruun, T.B.; Guardiloa-Claramonte, M.; Giambelluca, T.W.; Lawrence, D.; Nguyen Thanh, L. Environmental consequences of the demise in swidden cultivation in montane mainland Southeast Asia: Hydrology and geomorphology. Hum. Ecol. 2009, 37, 361-373. [CrossRef]

190. Henley, D. Swidden farming as an agent of environmental change: Ecological myth and historical reality in Indonesia. Environ. Hist. 2011, 17, 525-554. [CrossRef]

191. Ty, P.H.; Van Westen, A.C.M.; Zoomers, A. Compensation and Resettlement Policies after Compulsory Land Acquisition for Hydropower Development in Vietnam: Policy and Practice. Land 2013, 2, 678-704. [CrossRef]

192. Polesny, Z.; Verner, V.; Vlkova, M.; Lojka, B.; Banout, J.; Valicek, P.; Mazancova, J. Non-timber forest products utilization in Phong Dien Nature Reserve, Vietnam: Who collects, who consumes, who sells? Bois Forêts Trop. 2014, 322, 39-49. [CrossRef]

193. Boissière, M.; Sheil, D.; Basuki, I. A booming trade? How collection of war residues affects livelihoods and forest in Vietnam. Int. For. Rev. 2011, 13, 404-415. [CrossRef]

194. Sovu; Tigabu, M.; Savadogo, P.; Odén, P.C.; Xayvongsa, L. Recovery of secondary forests on swidden cultivation fallows in Laos. For. Ecol. Manag. 2009, 258, 2666-2675. [CrossRef]

195. Dung, N.T.; Webb, E.L. Reconciling science and indigenous knowledge in selecting indicator species for forest monitoring. In Redefining Diversity and Dynamics of Natural Resources Management in Asia, Volume 3. Natural Resource Dynamics and Social Ecological Systems in Central Vietnam: Development, Resource Changes and Conservation Issues; Thang, T.N., Dung, N.T., Hulse, D., Sharma, S., Shivakoti, G., Eds.; Elsevier: Amsterdam, The Netherlands, 2016; pp. 125-138.

196. Nghia, N.H. Forest Rehabilitation in Vietnam. In Keep Asia Green. Volume 1: Southeast Asia; IUFRO World Series Volume, 20-1; Lee, D.K., Ed.; International Union of Forest Research Organizations (IUFRO): Vienna, Austria, 2007; pp. $209-242$.

197. De Jong, W.; Chokkalingam, U.; Perera, G.A.D. The evolution of swidden fallow secondary forests in Asia. J. Trop. For. Sci. 2001, 13, 800-815.

198. Dawson, I.K.; Leakey, R.; Clement, C.R.; Weber, J.C.; Cornelius, J.P.; Roshetko, J.M.; Vinceti, B.; Kalinganire, A.; Tchoundjeu, Z.; Masters, E.; et al. The management of tree genetic resources and the livelihoods of rural communities in the tropics: Non-timber forest products, smallholder agroforestry practices and tree commodity crops. For. Ecol. Manag. 2014, 333, 9-21. [CrossRef]

199. Tatarski, M. 'Drastic Forest Development': Vietnam to Plant 1 Billion Trees-but How? Mongabay. 2021. Available online: https: / / news.mongabay.com/2021/05/drastic-forest-development-vietnam-to-plant-1-billion-trees-but-how/ (accessed on 10 August 2021).

200. Perz, S.G. Grand Theory and Context-Specificity in the Study of Forest Dynamics: Forest Transition Theory and Other Directions. Prof. Geogr. 2007, 59, 105-114. [CrossRef]

201. Van Holt, T.; Binford, M.W.; Portier, K.M.; Vergara, R. A stand of trees does not a forest make: Tree plantations and forest transitions. Land Use Policy 2016, 56, 147-157. [CrossRef]

202. Le, S.; Bond, J.; Le, P.T.H.; Winkel, A.; Uy, T.C.; van Le, N. The importance of climate change awareness for the adaptive capacity of ethnic minority farmers in the mountainous areas of Thua Thien Hue province. Local Environ. 2021, 26, 1-13.

203. Sikor, T.; Martin, A.; Fisher, J.; He, J. Toward an Empirical Analysis of Justice in Ecosystem Governance. Conserv. Lett. 2014, 7, 524-532. [CrossRef] 